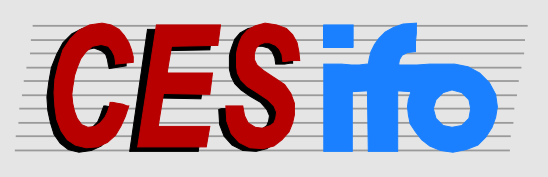

\title{
Working
}

Papers

www.cesifo.org/wp

\section{Effects of Psychiatric Disorders on Labor Market Outcomes: A Latent Variable Approach Using Multiple Clinical Indicators}

\author{
Souvik Banerjee \\ Pinka Chatterji \\ Kajal Lahiri
}

CESIFO WORKING PAPER NO. 4260

CATEGORY 4: LABOUR MARKETS

MAY 2013

An electronic version of the paper may be downloaded

- from the SSRN website:

- from the RePEc website:

- from the CESifo website:

wWw.SSRN.com

www.RePEc.org

www.CESifo-group.org/wp

\section{CESifo}




\title{
Effects of Psychiatric Disorders on Labor Market Outcomes: A Latent Variable Approach Using Multiple Clinical Indicators
}

\begin{abstract}
In this paper, we estimate the effect of psychiatric disorders on labor market outcomes using a structural equation model with a latent index for mental illness, an approach that acknowledges the continuous nature of psychiatric disability. We also address the potential endogeneity of mental illness using covariance instruments as suggested in Lewbel (2012), thus not requiring questionable exclusion restrictions for identification. Data come from the US National Comorbidity Survey - Replication (NCS-R) and the National Latino and Asian American Study (NLAAS). We find that depression and generalized anxiety disorder detract from the employment and labor force participation of males and females; however, we do not find evidence of adverse effects of panic attack or social phobia on any work outcomes of either males or females. After addressing the potential endogeneity of mental illness, we continue to find that mental illness adversely affects employment and labor force participation for both males and females, but the effect on weeks worked and days missed at work are significant for males only. Using our structural model we assess the policy implications of some of the recommendations in the Affordable Care Act, relating to expansion of benefits for mental health and substance use disorder benefits. We find potential gains in employment for 3.2 million individuals and reduction in workplace cost of absenteeism of $\$ 18.9$ billion due to improved mental health of individuals who are in most need of treatment.
\end{abstract}

JEL-Code: I100.

Keywords: mental illness, labor market outcomes, depression, employment.

\author{
Souvik Banerjee \\ Department of Economics \\ University at Albany \\ USA - Albany NY 12222 \\ sbanerjee@albany.edu
}

\author{
Pinka Chatterji \\ Department of Economics \\ University at Albany \\ USA - Albany NY 12222 \\ pchatterji@albany.edu
}

\author{
Kajal Lahiri \\ Department of Economics \\ University at Albany \\ USA - Albany NY 12222 \\ klahiri@albany.edu
}

\begin{abstract}
This research was supported by the National Institute on Minority Health and Health Disparities, National Institutes of Health (grant number 1 P20 MD003373). The content is solely the responsibility of the authors and does not represent the official views of the National Institute on Minority Health and Health Disparities or the National Institutes of Health. We thank Margarita Alegria for information regarding diagnostic algorithms, Benjamin Cook and also conference participants at the New York Camp Econometrics, April, 2013 and Ifo/CESifo \& University of Munich \& MEA Conference on Empirical Health Economics, Feb., 2013 for comments and suggestions, but retain the responsibility for any errors and shortcomings in the paper.
\end{abstract}




\section{Introduction}

The wide-ranging labor market consequences associated with mental illness have been welldocumented. ${ }^{4}$ Mental disorders are associated with unemployment, lower earnings, work absences, reduced labor supply, and lower on-the-job productivity. The annual earnings loss associated with serious mental illness in the US was estimated to be over \$193 billion in 2001-2003 alone (Kessler et al. 2008). The main emphasis in the economics literature on mental illness and labor market outcomes has been on testing whether the observed association between mental illness and labor market outcomes reflects a causal relationship. Mental illness may be endogenous to labor market outcomes in a structural sense, if these outcomes are determined simultaneously, and/or in a statistical sense, if there are difficult-tomeasure characteristics, such as personality traits and family background, which are correlated with mental illness and directly related to labor market outcomes. In prior work, researchers have addressed the potential endogeneity of mental disorders with respect to labor market outcomes using a variety of approaches. ${ }^{5}$ In most prior studies, there are conceptual as well as empirical concerns about the validity of the identification strategy, and dealing with these issues is the focus of this literature.

Although there has been much interest in this area in testing for causality between mental disorders and labor market outcomes, one important aspect which has largely been neglected is the measurement of the mental health variable itself. Many of the most recent economic studies in this area are based on state-of-the-art surveys which include a fully structured, diagnostic psychiatric interview. These studies typically use an indicator variable (1, if an individual meets diagnostic criteria for a particular mental disorder and 0, otherwise) as the regressor of primary interest. Dichotomous indicators are easy to interpret, and, in epidemiological work, they are useful for measuring and tracking changes in

\footnotetext{
${ }^{4}$ A recent OECD report highlights the labor market burden of mental illness. See OECD (2011).

${ }^{5}$ These approaches include bivariate probit models (Frijters et al. 2010; Ettner et al. 1997; Ojeda et al. 2010; Chatterji et al. (2007, 2011); Lu et al. 2009; DeSimone 2002); 2 stage least squares (Frijters et al. 2010; Chatterji et al. (2007, 2011); Lu et al. 2009; Renna 2008); fixed effects models (Frijters et al. 2010); OLS/probit/logit/tobit models (with lagged values of mental health status to minimize reverse causality) (Bartel and Taubman $(1979,1986) ;$ Mitchell and Anderson1989); simultaneous equation models ( to explicitly model the two way relationship between labor market outcomes and mental health) (Chang et al. 2011).
} 
disease prevalence. However, the shortcoming of using such a measure in examining the effect of mental illness on labor market outcomes is that it dichotomizes a health condition that is inherently continuous, and it assumes away any heterogeneity in the population in the way psychiatric symptoms affect work capacity. In other words, using dichotomous indicators for mental illness ignores individuals who do not pass the threshold for clinical diagnosis of any particular mental disorder, but, nonetheless, could have a range of sub-threshold symptoms that cause significant work-related impairments. This issue has been recognized by policymakers in the US. Notably, in the 1980's, screening criteria for federal disability benefits programs were modified such that more consideration was given to work functioning rather than strict psychiatric diagnosis, and non-severe, multiple impairments potentially could be viewed as work disabling (Lahiri et al. (1995, 2008); Autor \& Duggan 2003).

In this paper, we estimate the effect of mental illness on labor market outcomes using a structural equation modeling framework with a Multiple Indicator and Multiple Cause (MIMIC) (Joreskog and Goldberger 1975; Goldberger 1972; Hauser and Goldberger 1971) model embedded in the structure. A latent index for mental health is generated from the model using multiple indicators (symptoms) and multiple causes (determinants) of psychiatric disorders and the different indicators are linked to the labor market outcome measures. Thus, the latent measure reflects the fact that not all psychiatric symptoms are equally important in explaining the labor market behavior of individuals. In fact, using this approach, we can identify which symptoms and clusters of symptoms are most important to particular labor market outcomes, and potentially also simulate the labor market benefits of particular treatments. Notably, our approach incorporates the high levels of co-morbidity between different psychiatric conditions because the latent index is constructed based on all psychiatric symptoms, not just those that correspond to a particular disorder.

Data come from two unique and recently publicly available datasets, the National Comorbidity Survey Replication (NCS-R) and the National Latino and Asian American Study (NLAAS) which include a fully structured diagnostic assessment of mental disorders and also rich data on the correlates of mental 
disorders. We study the impact of mental illness on a wide range of labor market outcomes (employed, in labor force, number of weeks worked for pay in the past 12 months among employed individuals and number of full days of work missed during the last 30 days conditional on being employed) to account for the manifold effects of mental illnesses.

Our main contribution to the existing literature is the use of a continuous latent index for mental disorder to assess the impact on a range of labor market outcomes. In addition, a secondary contribution is that we address the potential endogenous nature of the mental illness variable by using covariance instruments, proposed by Lewbel (Lewbel 2012), which, to our knowledge, has not been used previously in this literature. Lewbel argues that the covariance restrictions imposed are reasonable in many classes of models where there are measurement error problems or the error correlations are due to an unobserved common factor. Further, this identification strategy is most useful in situations where the conventional instruments are either weak or unavailable (Lewbel 2012). This makes a strong case for using this approach in our context. We show the usefulness of our structural modeling approach in a practical application by assessing the potential labor market benefits from expanding access for mental health and substance use disorder services and treatment alternatives, as laid out in the Affordable Care Act. To this end we conduct a counterfactual simulation exercise, whereby, we simulate the employment effects of amelioration of mental health of individuals who are in most need of treatment, by using the "Rank and Replace" method (McGuire et al. 2006; Cook et al. 2009, 2010).

\section{Prior Research}

In this section, we review recent, economics papers which have examined the causal impact of psychiatric disorders on labor market outcomes of individuals. For our purposes, these papers can be roughly divided into two groups - papers which use a binary indicator for the presence/ absence of a mental disorder, and papers which use a continuous measure of mental illness or psychological distress. 
Most papers utilizing a binary measure of mental disorder are based on either the 1990 National Comorbidity Survey (NCS), the 2001-2003 Collaborative Psychiatric Epidemiologic Surveys (CPES), or the National Survey on Drug Use and Health (NSDUH), since these three groups of surveys are the only large-scale surveys to include diagnostic interviews and a range of standard measures of mental health. For example, Ettner et al. (1997) use data from the National Comorbidity Survey (NCS) to examine the effect of psychiatric disorders on employment, and among those employed, income and work hours. Using an instrumental variable approach, with the number of psychiatric disorders of the respondent's parents and number of psychiatric disorders experienced by the respondent before age 18 as identifying instruments, the authors find that the presence of any mental disorder detracts from employment by about 11 percentage points or a little more, depending on the specification of the model, for both men and women. They also find small reductions in work hours for men and a significant fall in incomes of both men and women, conditional on employment. It is important to point out that their single equation estimates, which do not account for endogeneity of the mental disorder variable, are very similar to their IV estimates.

Similarly, Chatterji et al. (2007) is the first study to look at the employment effects of mental disorders for a population which comprises mostly immigrants - Latinos and Asians. They use data from the National Latino and Asian American Study (NLAAS) and use an IV estimation, with number of psychiatric disorders prior to age 18 (similar to Ettner et al. 2007), religious attendance, and seeking religious or spiritual means to handle problems as instruments. The authors find that among Latinos, mental disorders have an adverse effect on employment and absenteeism, similar to US born population, whereas, there is no such clear evidence for Asians. Another recent study which also examines the effect of nativity and mental health on employment and full-time work is by Ojeda and coauthors (Ojeda et al. 2010). They use three different specifications of the bivariate probit model, each using a different set of instruments (measures of social support; self-reported symptoms of mania and delusions; measures which include both social support and symptoms of mania and delusions). Their data come from the National 
Survey on Drug Use and Health (NSDUH).Using the K-6 scale of mental illness, the authors find that mental illness lowers employment rates for US born males but has no significant impact on immigrants.

Finally, Chatterji et al. (2011) use different specifications of models to achieve identification using the National Comorbidity Survey -- Replication (NCS-R) dataset. Using a method proposed in Altonji et al. (2005), if selection along unmeasured factors is set equal to selection along measured factors, the authors find reduction in the probability of current labor force participation by 9 and 19 percentage points for males and females respectively and reductions in the order of 14 and 13 percentage points in the likelihood of being currently employed. The results based on estimation using bivariate probit models are also very similar to the above findings.

As a group, these studies show large effects of mental disorders on labor market outcomes, but individuals are classified as not having mental illness if they do not meet the diagnostic threshold for any particular disorder, even though they may be having sub-threshold levels of symptoms for several different disorders, or sub-threshold levels of symptoms that are particularly harmful for labor market outcomes. ${ }^{6}$ Studies based on symptom scales show that higher levels of symptoms are associated with worse labor market outcomes. Hamilton et al. (1997), for example, use a simultaneous equation generalized probit model to estimate the relationship between mental health and employment jointly in a sample of residents from Montreal. They use the Psychiatric Symptom Index (PSI) as a measure of mental illness, with a range from 0 to 87 , and a higher score indicating higher symptomatology of depression, anxiety, anger and cognitive disturbance. Consistent with previous findings in the literature, the authors observe significant adverse effect of mental illness on employability.

Another example is Lu et al. (2009) who examine the impact of mental health on employment outcomes in China using the China Health Surveillance Baseline 2001 survey. The mental health index is constructed from 8 questions which focus on symptoms of depression and anxiety. The index ranges from

\footnotetext{
${ }^{6}$ Broadhead et al. (1990) find that even milder forms of depression substantially increased the number of disability days in a 3 month follow up period.
} 
9 to 40 , with lower scores indicating worse mental health. The authors find good mental health to have a positive impact on the likelihood of being employed, but no significant effect on annual earnings.

Finally, Frijters et al. (2010) examine the relationship between mental health and labor force participation (either employed or unemployed but looking and available for work) in Australia. The data used in the paper comes from the Household Income and Labour Dynamics (HILDA) survey, which is a panel study. Frijters et al. (2010) use data from 2002 to 2008 and use a variety of models to compare the results obtained from treating mental health as exogenous and when it is potentially endogenous. The authors use a subset of questions from the mental health module of the Short Form General Health Survey (SF-36) to create a mental health index and then standardize it so that the mean is zero and standard deviation one. The linear probability and probit models indicate a 6 percentage point increase in the likelihood of labor force participation when mental health improves by one standard deviation. When the possible endogeneity is accounted for, by using recent death of a close friend as an instrument, the estimates indicate much larger effects from improved mental health.

The disadvantage of these studies based on symptom scales is it is unclear which symptoms are driving the effects on labor market outcomes. Also, these symptoms included in the scales are not necessarily part of the diagnostic criteria used to determine psychiatric diagnosis, which makes it hard to interpret findings.

Using data from a clinical trial in the US, Berndt et al. (1998) look at the short term impact of chronic depression and its treatment on work performance. The individuals used in the trial are observed at the baseline period, after 4 weeks and finally at the end of 12 weeks. Using the Hamilton Depression Rating Scale (HAMD) the authors find that the work performance of chronically depressed individuals is negatively associated with the severity of the depression and a reduction in the severity improves performance at work. Berndt et al. (1998) further find that the greatest improvements in performance are for those who had low work performance and low severity of depression at the base period. 
The main contribution of our paper is that we use a structural equation modeling approach with latent indices for mental disorders, whereby, we simultaneously estimate the determinants of labor market outcomes and mental disorders, and also the loadings of different symptoms on mental health. One of the main advantages of estimating all the equations together under one roof is that the model picks out those indicators of a mental disorder which are important in explaining the labor market outcome variable. Within disorder classes (for example, major depression), we can identify the symptoms that are most important in affecting work capacity using this approach. More broadly, we also can identify psychiatric symptoms across disorder classes that have important effects on work capacity. This is important since some disorders have similar symptoms, and there are high levels of co-morbidity across disorders. In sum, because our modeling approach links the different measurements of a mental disorder to the labor market outcome variable, we are able to create a latent index of a mental disorder which is more nuanced, better at capturing the true continuous and highly co-morbid nature of psychiatric disability, and is perhaps better in predicting the employment outcome variable.

\section{Empirical Model}

\section{Bivariate probit and 2SLS models}

Before we discuss our estimation strategy, we shall outline the standard methodological approach in the literature, which seeks to examine the impact of having any mental disorder in the past 12 months prior to the survey on the work related outcomes of individuals. The model is as follows:

$$
\begin{aligned}
& L=\theta+\beta X+\mu M+u_{1} \\
& M=\delta+\pi X+\rho W+u_{2}
\end{aligned}
$$


In equations $(i)$ and $(i i), L$ represents the labor market outcome of interest; $M$ is a binary indicator of whether an individual had had any mental disorder ${ }^{7}$ in the past 12 months; $\theta$ and $\delta$ are intercepts; $X$ is a set of demographic and socioeconomic control variables; $W$ is an instrument for $M$; and $u_{1}$ and $u_{2}$ are error terms. Even though exclusion restrictions are not required for identification due to non-linearity of the model, typically instrumental variables are used to sharpen identification. The above model represents a bivariate probit model in the case that $L$ represents a binary labor market outcome. The bivariate probit model assumes the errors $\left(u_{1}, u_{2}\right)$ are distributed jointly normal and the equations are estimated simultaneously using a maximum likelihood procedure. In the event that $L$ is a continuous measure we use a standard two stage least squares (2SLS) procedure.

\section{Structural equation models (SEMs)}

In order to examine the impact of mental disorders on labor market outcomes, we use a structural equation model. Our basic specification of the model takes the following form:

Model I:

$$
L^{*}=\theta+\beta X+\mu \text { Mental }^{*}+u_{1}
$$

In case of binary labor market outcomes,

$$
\begin{aligned}
& L=\left\{\begin{array}{l}
1 \text { if } L^{*}>0 \\
0 \text { if } L^{*} \leq 0
\end{array}\right. \\
& \text { Mental }^{*}=\delta+\pi X+u_{2} \\
& y_{1}=\gamma_{1}+\alpha_{1} \text { Mental }^{*}+\varepsilon_{1} \\
& y_{2}=\gamma_{2}+\alpha_{2} \text { Mental }^{*}+\varepsilon_{2} \\
& \cdot \\
& \cdot \\
& y_{n}=\gamma_{n}+\alpha_{n} \text { Mental }^{*}+\varepsilon_{n}
\end{aligned}
$$

\footnotetext{
${ }^{7}$ The psychiatric disorders typically considered in studies based on the NCS-R and the CPES are: Major Depressive Episode, Dysthymia, Agoraphobia, Generalized Anxiety Disorder, Panic Attack, Panic Disorder, Social Phobia, Alcohol Abuse, Alcohol Dependence, Drug Abuse, Drug Dependence, Post-Traumatic Stress Disorder, Anorexia and Bulimia.
} 
where, $L^{*}(L)$ denotes the labor market outcome; Mental ${ }^{*}$ is a latent (unobserved) measure of a particular mental disorder in the past 12 months; $\theta, \delta$ and $\left(\gamma_{1}, \gamma_{2}, \ldots, \gamma_{n}\right)$ are intercept terms; $X$ is a vector of demographic and socioeconomic variables which may affect the outcome variable and also the mental health of an individual; $\left(y_{1}, y_{2}, \ldots, y_{n}\right)$ are indicators (effects) of a mental disorder ; $u_{1}, u_{2}$ and $\left(\varepsilon_{1}, \varepsilon_{2}, \ldots, \varepsilon_{n}\right)$ are error terms. In this baseline model we assume that $\left(u_{1}, u_{2}\right)=\operatorname{cov}\left(\varepsilon_{i}, \varepsilon_{j}\right)=$ $\operatorname{cov}\left(u_{k}, \varepsilon_{i}\right)=0 ; i, j=1,2, \ldots, n ; i \neq j ; k=1,2$. Our primary coefficient of interest is $\mu$, which measures the effect of mental disorder on the labor market outcome of interest. Equations (1) and (1a) constitute the labor market equation, equation (2) comprises the multiple causes (determinants) of the psychiatric disorder and equations (3) - (5) consist of multiple indicators of the mental disorder. Thus, equations (2) (5) make up the standard MIMIC model framework. The set of equations (1) - (5) form a structural equation model - in the sense of establishing causal relationships (Goldberger, 1973) among observed variables and hypothetical construct(s) (latent variable(s)), which are not observed by the researcher. These theoretical construct(s), though not directly observable, have implications for relationships among observable variables (Joreskog and Goldberger, 1975). The observable variables in our model appear as different causes (vector $X$ in equation (2)) and different effects $\left(\left(y_{1}, y_{2}, \ldots, y_{n}\right)\right.$ in equations (3) - (5)) of the underlying latent variable, which measure the severity of a mental disorder.

It is important to point out that in this baseline model we do not account for co-morbidities between psychiatric disorders. Presence of several mental health conditions is significantly related to greater severity of problems and more substantial functional impairments (Kessler et al. 2005; Andrews et al. 2001).The presence of symptoms of other psychiatric disorders might be correlated with both the labor market variable and also the latent variable of interest - thus biasing the estimates. If the symptoms of other disorders are positively correlated with the latent variable and also detract from positive employment outcomes (being employed, participation in the labor force), then the coefficient on the latent variable in equation (1) will overstate the effect of the disorder on the labor market variable. 
Besides looking at the effects of individual psychiatric disorders, we also want to explore the impact of one composite index, measuring the severity of mental illness, on work outcomes of individuals. To this effect, we use the following model:

Model II:

$$
L^{*}=\theta+\beta X+\mu M I^{*}+u_{1}
$$

In case of binary labor market outcomes,

$$
\begin{aligned}
& L=\left\{\begin{array}{l}
1 \text { if } L^{*}>0 \\
0 \text { if } L^{*} \leq 0
\end{array}\right. \\
& M I^{*}=\delta+\pi X+\lambda V+u_{2} \\
& y_{1}=\gamma_{1}+\alpha_{1} M I^{*}+\varepsilon_{1} \\
& y_{2}=\gamma_{2}+\alpha_{2} M I^{*}+\varepsilon_{2} \\
& \cdot \\
& \cdot \\
& y_{n}=\gamma_{n}+\alpha_{n} M I^{*}+\varepsilon_{n}
\end{aligned}
$$

$M I^{*}$ is a latent index for mental illness in the last 12 months; $\left(y_{1}, y_{2}, \ldots, y_{n}\right)$ is the set of indicators for all mental disorders considered in the analysis; and $V$ is a set of instruments for $M I^{*}$. We address the endogeneity of mental illness by allowing the errors in equation (1b) and ( $2 b)$ to be correlated, i.e. we allow $\operatorname{cov}\left(u_{1}, u_{2}\right) \neq 0$ and use number of psychiatric disorders with onset prior to age $18^{8}$ as an instrument for the possibly endogenous mental illness latent variable. Although the aforementioned instrument has been used in prior research (Ettner et al. 1997 ; Chatterji et al. 2007,2011) there are conceptual as well as empirical issues about its validity (Chatterji et al. 2011). For example, individuals who have a weak personality (unobserved) may be both more likely to have a psychiatric disorder in

\footnotetext{
${ }^{8}$ The disorders considered for the instrument are Dysthymia, Major Depressive Disorder, Major Depressive Episode, Agoraphobia, Generalized Anxiety Disorder, Panic Attack, Panic Disorder, Post-Traumatic Stress Disorder, Social Phobia, Alcohol Abuse, Alcohol Dependence, Drug Abuse, Drug Dependence, Anorexia, Binge Eating Disorder, Bulimia and Intermittent Explosive Disorder.
} 
childhood and more likely to fare poorly in the labor market after controlling for possible mediating factors like education and marital status. In this case, the instrument would not be valid.

As an alternative to this standard IV method we use an approach suggested in Lewbel (2012) which is based on the heteroskedasticity of the error term in equation (2b). Lewbel (2012) shows that $\mu$ can be estimated consistently using $(Z-\bar{Z}) \widehat{u_{2}}$ as instruments ${ }^{9}$ in equation (2b) under the assumption that $\operatorname{cov}\left(Z, u_{2}^{2}\right) \neq 0$ and $\operatorname{cov}\left(Z, u_{1} u_{2}\right)=0 . Z$ is a vector of covariates, which could be the entire vector of covariates $X$ or a subset of $X$ used in equations (1b) and (2b) and $\bar{Z}$ is the mean of $Z$. The residual $\widehat{u_{2}}$ from equation (2b) was computed using the following procedure: (i) we estimated equations (2b) - (5b) and obtained the predicted value for the latent mental illness index, $\widehat{M I}$, then (ii) we regressed $\widehat{M I}$ on the constant $\delta$ and $X$ to obtain the predicted value of $\widehat{M I}, \widetilde{M I}$. The residual $u_{2}=\widehat{M I}-\widetilde{M I}$. Since the applicability of the Lewbel (2012) approach hinges on the assumption of heteroskedasticity of the error term $\mathrm{u}_{2}$, we conducted a Breusch-Pagan (1979) test which rejected the null hypothesis of homoskedasticity.

\section{Data}

The data used in this study comes from the combined sample of the National Comorbidity Survey Replication (NCS-R) (NCS-R; Kessler et al. 2004) and the National Latino and Asian American Study of Mental Health (NLAAS) (NLAAS; Alegria et al. 2004), which are a part of the Collaborative Psychiatric Epidemiology Studies (CPES), funded by the National Institute of Mental Health (NIMH) and collected by the University of Michigan Survey Research Center (SRC). Data collected for the NCS-R and the NLAAS is based on a multi-stage area probability sample including the following four steps: first stage sampling of US Metropolitan Statistical Areas (MSAs) and counties; second stage sampling of area segments; selection of the housing units from the area segments in the third stage; and finally, randomly selecting the eligible respondents from the selected housing units (Heeringa et al. 2004). The studies

\footnotetext{
${ }^{9}$ We refer to these instruments as covariance instruments in the paper.
} 
include detailed information on the distributions, risk factors and correlates of mental disorders as well as health services use along with rich data on demographic, socioeconomic, family background and employment characteristics of the individuals, which are relevant for our study.

The NCS-R is a nationally representative household survey of the non-institutionalized, English speaking population who are 18 years and older and living in the coterminous states of the US. The survey comprised two parts -- Part I including a core diagnostic assessment, with a sample size of 9282; and Part II being administered to all the respondents from Part I of the survey who met lifetime criteria for any disorder as well as a probability sample of new respondents (sample size $=5692$ ). The response rate for the survey was 70.9\% (Heeringa et al. 2004) and the data was collected between February 2001 and April 2003.

The NLAAS included non-institutionalized Latino and Asian Americans residing in the coterminous states in the US. Latinos were categorized under the following heads: Mexican, Cuban, Puerto Rican and all other Latinos; whereas, Asian Americans were classified based on their ancestry or national origin as: Chinese, Filipino, Vietnamese and all other Asians. The data collection process was completed by late fall 2003. The Latino sample comprised 2554 individuals, with a response rate of $75.5 \%$ and the Asian American sample included 2095 individuals with a response rate of 65.6\% (Heeringa et al. 2004).

The initial sample with which we begin with consists of 10,341 individuals from Part II of the NCSR and the NLAAS. We excluded individuals who were either less than 25 years old or older than 64 years old $(n=2577)$, individuals with missing values for the work status variable $(n=13)$ and individuals with missing values for symptoms of disorders $(n=11)$. Since we focus on Asians (Vietnamese, Filipino, Chinese, all other Asians), Latinos (Cuban, Puerto Rican, Mexican, all other Hispanic), African Americans and Non-Latino Whites (baseline category) in our study, we excluded those individuals who 
reported their race to be different from the above categories $(n=223)$. The final sample with which we work with consists of 7566 individuals ${ }^{10} ; 4235$ women and 3331 men.

The dependent variables are measures of labor market outcomes at the time of the survey: (i) whether an individual is employed, (ii) whether an individual is part of the labor force, (iii) number of weeks worked in the past 12 months conditional on being employed and (iv) number of full days of work missed in the last 30 days conditional on being employed. The employment variable is a binary indicator for whether the individual is currently employed for pay (part-time or full-time); the labor force participation variable is also a binary indicator, indicating whether the respondent is currently a part of the labor force (employed/ unemployed vs. not in the labor force). Both of these variables were created from a question about the individual's current work status.

Our primary covariate of interest is an underlying latent (unobserved) variable of a psychiatric disorder in the past 12 months; namely, major depressive episode (MDE), panic attack, social phobia and generalized anxiety disorder (GAD). We work with these 4 disorders since they are the most prevalent 12-month hierarchy free psychiatric disorders ${ }^{11}$ which are evaluated using the World Health Organization Composite International Diagnostic Interview (WMH-CIDI) (Kessler et al. 2004). The latent variable for each mental disorder is reflective of a set of symptoms, severity and length of episode questions ${ }^{12}$ which are used in the Diagnostic and Statistical Manual of Mental Disorders, 4th edition (DSM-IV) for diagnosis of a psychiatric disorder; and several determinants (causes) of the disorders, including demographic, socioeconomic, family background and chronic physical conditions variables. The symptoms questions used in the study for diagnosis of a disorder are indicative of symptoms in the past 12 months. The symptom variable is assigned a value 1 if the individual had the particular symptom and

\footnotetext{
${ }^{10}$ There are some observations with missing values in more than one category. Therefore, the total number of missing observations is greater than the number of observations excluded from the sample.

${ }^{11}$ We do not include specific phobia, nicotine dependence and intermittent explosive disorder, even though they are prevalent in the general population, because the questions which are used for diagnosis of these psychiatric disorders were not asked of all individuals in the sample.

${ }^{12}$ See Table 1 for a list of questions used for each psychiatric disorder. Questions related to work were excluded to avoid reverse causality problem.
} 
had an episode of the corresponding disorder in the past 12 months, and 0 otherwise ${ }^{13}$. Subsequently, we use a single underlying latent index for mental illness, incorporating all the indicator variables which are used previously for the individual psychiatric disorders and the same causal variables.

In all the different specifications of the models we control for age, age squared, race/ethnicity ( Asian, Latino, African American, with Non-Latino Whites as the baseline category), marital status (married, widowed/ divorced/ separated with single as the baseline), educational attainment (12 years, 13-15 years, 16 or more years, with less than 12 years as the baseline category), presence of any physical medical conditions and region of residence (Midwest, South, West with Northeast as the reference group). The physical medical conditions is a dichotomous indicator, equal to 1 if an individual reported having Arthritis/Rheumatism, Stroke, Heart Attack, Diabetes, Ulcer or Cancer at any point during their lifetime and 0 , otherwise. We conduct all analysis separately for males and females since the prevalence of mental disorders and labor market outcomes differ significantly by gender.

The identifying instrumental variable used is number of psychiatric disorders (dysthymia, major depressive disorder, major depressive episode, agoraphobia, generalized anxiety disorder, panic attack, panic disorder, post-traumatic stress disorder, social phobia, alcohol abuse, alcohol dependence, drug abuse, drug dependence, anorexia, binge eating disorder, bulimia, intermittent explosive disorder) with onset before age 18. In order to implement the Lewbel (2012) approach, we use a subset of $X$ covariates as the vector Z; namely, a binary indicator for whether an individual is married or not and number of early onset of psychiatric disorders.

\footnotetext{
${ }^{13}$ Here we assume that if the respondent had an episode of a disorder in the last 12 months, the response to the symptom question would correspond to that episode.
} 


\section{Results}

\section{Summary statistics}

In Table 1 we report the weighted means of the variables used in our study. Compared to $84 \%$ of males, $69 \%$ of females are employed; $86 \%$ and $75 \%$ of males and females resp. are part of the labor force; employed males work about 51 weeks a year relative to 49 weeks for employed females; and both males and females miss about 1 day of work in the past month conditional on being employed. The prevalence rate for any psychiatric disorder in the past 12 months is $29 \%$ for women compared to $20 \%$ for men; length of depressive episode is higher for women than for men - little more than 3.5 months compared to under 2.5 months for men; among women $14 \%$ and $12 \%$ had symptoms of depressed mood and diminished pleasure resp. in the past 12 months compared to $9 \%$ and $8 \%$ for men. Among women $10 \%$ had symptoms of choking, $12 \%$ feared a social situation, $9 \%$ was afraid of meeting new people, $11 \%$ had symptoms of excess anxiety and $10 \%$ had symptoms of restlessness in the past 12 months. For men the figures were $5 \%, 9 \%$ and $7 \%$ for symptoms of choking, fearing a social situation and afraid of meeting new people resp. and $6 \%$ for symptoms of excess anxiety and restlessness in the last year.

\section{Bivariate probit and 2SLS results}

In Tables 2 and 3 we present the results for the effect of having any mental disorder in the past 12 months on the labor market outcomes for males and females respectively. In the odd numbered columns we report the estimates without addressing the endogeneity of the mental disorder variable and in the even numbered columns allow for the possibility that mental disorders is potentially endogenous. We find significant negative effect of having a psychiatric disorder on the likelihood of being employed and participating in the labor force for both men and women. The effects are higher after we address endogeneity of psychiatric disorders. The 2SLS results suggest that having a disorder in the past 12 months has no significant impact on the number of weeks worked and number of days missed for males; however, it reduces the number of weeks worked for females by more than 3 weeks. 


\section{SEM results}

\section{Model I}

We display the results of the impact of MDE on work outcomes of males and females in Table 4. As expected, we find significant adverse effect on all outcomes for both males and females, except we do not find any significant effect on number of full days of work missed in the past 30 days for females. The magnitude of the effects is larger for males compared to females. Insomnia or hypersomnia, indecisiveness and severe emotional distress for both men and women, and symptom of fatigue for women are the most important indicators of MDE in the context of labor market outcomes.

In Table 5 we report the findings of the effect of panic attack on the outcomes. We observe significant negative impact of panic attack on employment and labor force participation for men and women and a substantial reduction in the number of weeks worked for men, but no impact on the weeks worked for women. Symptoms of choking and those of dizziness or unreality are crucial indicators of panic attack for men; whereas, choking and symptom of chest pain or nausea are vital for predicting panic attack for women.

In Table 6 we show the results for the effect of social phobia on labor market outcomes for males and females. Here we find significant differences in the impact of the disorder for men and women. Social phobia has a detrimental effect on the likelihood of being employed, being a part of the labor force and number of missed days for men; however, there is no significant impact on any work outcomes for women. Fear of embarrassment, fear of social situations and an occurrence of a feared or avoided social situation after age 18 are important indicators of social phobia when these are also associated with the labor market outcomes.

Results from the model examining the effect of GAD are displayed in Table 7. In conformity with our expectations we see a deleterious effect of GAD on all work outcomes for men and women, except on the 
number of weeks worked for women. The length of a GAD episode is the most important indicator of GAD, followed by symptoms relating to difficulty controlling worry and symptoms of worry/ anxiety/ nervousness causing significant emotional distress for both men and women.

\section{Model II}

In Table 8 we report our findings of the impact of mental illness on the likelihood that an individual is employed. In columns (1), (5) we do not address the endogeneity of mental illness; in columns (2), (6) we present estimates using number of psychiatric disorders with onset prior to age 18 as an instrument for the potentially endogenous mental illness latent variable; in columns (3) and (7) we use instruments suggested by Lewbel (2012), namely, (a) covariance instrument early onset of disorders, and (b) covariance instrument married ${ }^{14}$; finally, in columns (4) and (8) we use the covariance instruments mentioned above along with the external instrument number of psychiatric disorders with early onset. As anticipated, we find significant dampening effect of mental illness on employment regardless of the model specification. The coefficient on $M I^{*}$ in the labor market equation is higher after we account for endogeneity (columns (2) - (4) vs. column (1) for males and columns (6) - (8) vs. column (5) for females). The estimated effects are higher using the covariance instruments ( $\mu=-0.330$ for males and $\mu=-0.232$ for females) or the covariance instruments in conjunction with the external instrument $(\mu=-0.329$ and $\mu=-0.226$ for males and females resp.) compared to using only the external instrument $(\mu=-0.327$ and $\mu=-0.187$ for males and females resp.). Examining the results for those indicators (symptoms) which are most detrimental for work outcomes, we find that those for MDE are the most prominent ones. Length of a depressive episode, severe emotional distress, indecisiveness and insomnia/hypersomnia are the most important determinants of mental ill health for both men and women for explaining the employment status of individuals. In addition, we find that symptoms of fatigue are a crucial indicator of mental illness for women, but not so much for men. The results of the effect of mental ill health on labor force

\footnotetext{
${ }^{14}$ These instruments are defined in the Empirical Model section.
} 
participation of men and women are presented in Table 9. The estimated effects are very similar to those obtained in the previous table.

We present the results for the continuous work outcome variables in Tables 10 and 11. In Table 10 we report findings of the effect of mental illness on conditional number of weeks worked in the past year. We observe significant reduction in the number of weeks worked for both males and females $(\mu=-2.558$ and $\mu=-1.449$ resp.) when we do not allow for correlated errors in the labor market equation and the mental illness equation. Accounting for the potential endogeneity of mental illness we find much larger effects for men; however, the coefficient loses significance for the female sample in our preferred specification including the 3 instruments. In Table 11 the outcome of interest is number of days of work missed in the past month. We find poor mental health to significantly increase work absenteeism in the past month for males, but there is no significant impact for females.

\section{Validity of the instruments}

In order to test for the validity of the instruments we conducted a series of Hausman tests (Hausman 1978). First, we tested for the validity of the additional instrument "number of psychiatric disorders with onset prior to age 18" using " period of sadness for at least 2 weeks or period of constant anxiety/nervousness for at least 1 month during most of the respondent's childhood by either parents/ parental figure" as the baseline valid instrument ${ }^{15}$. We failed to reject the validity of the additional instrument for both the male and female samples (Male: Hausman statistic $(\mathrm{H})=0.007<26.30=\chi_{16}^{2}$; Female: $H=0.22<\chi_{16}^{2}$ ). In the second step using "number of psychiatric disorders with onset prior to age 18 " as a valid instrument for mental illness we tested for the validity of the two additional covariance instruments "covariance instrument early onset of disorders" and "covariance instrument married". Again, we failed to reject the validity of the two additional covariance instruments (Male: $\mathrm{H}=0.0007<$ $\chi_{16}^{2}$; Female: $\left.\mathrm{H}=0.77<\chi_{16}^{2}\right)$.

\footnotetext{
${ }^{15}$ We conduct this test using the NCS-R sample since our baseline instrument is not available in the NLAAS sample.
} 


\section{Concordance analysis}

As a way of comparing the frequently used binary indicator for meeting diagnostic criteria for a mental disorder with our latent continuous measure, we perform a concordance analysis ${ }^{16}$. In Figure1 we plot the conditional distributions of the predicted values of the latent indices ${ }^{17}$ for the psychiatric disorders given meeting or not meeting the diagnostic criteria. We find that individuals who meet requirements for clinical diagnosis of a disorder are more likely to receive a higher score on the latent scale, whereas those who fail to meet diagnostic criteria have a greater likelihood of receiving a lower value. To explore this further, we dichotomize over the relevant range on the latent scale given different alternative values for the cut-off points $(t)$. Thus individuals with a predicted score for the latent mental disorder variable to the left of $t$ are characterized as not having a disorder and those with a score greater than or equal to $t$ are classified as having the disorder. We define the hit rate $(H)$ as the proportion of correct diagnosis (based on our measure) when an individual meets diagnostic criteria for a disorder and the false alarm rate $(F)$ as the proportion of incorrect diagnosis when an individual does not meet diagnostic criteria. In terms of Table 12.1, $H=a /(a+c)$ and $F=b /(b+d)$. We use two measures to evaluate the performance of our latent indices vis-à-vis the standard binary variables used: (a) the Peirce skill score (PS) and (b) the odds ratio $(O R)$. $P S$ is the difference between the hit rate and the false alarm rate $(P S=H-F)$ and the odds ratio is defined as the ratio of the odds of making a correct prediction and the odds of an incorrect prediction $(O R=[H /(1-H)] /[F /(1-F)])$. A value of 0 for the $P S$ or alternatively, a value of 1 for the odds ratio indicates a perfect mismatch between our prediction (based on the latent index) for a psychiatric disorder and a clinical diagnosis of the disorder. In Table 12.2 we report our findings for the different measures for each of the psychiatric disorders used in our study. Our preferred choice of cutoff

\footnotetext{
${ }^{16}$ See Lahiri et al. (2013) for further details.

${ }^{17}$ The predicted values are obtained using the multiple indicator equations (eqns. (3)-(5')) in Model I.
} 
value is one which maximizes $P S$ and/or $O R^{18}$. Thus, we choose $t=0.2$ for MDE, $t=0$ for panic attack, $t=0.5$ for social phobia and $t=0.3$ for GAD. In Table 13 we present contingency tables for clinical diagnosis and diagnosis of a mental disorder based on the cutoff values chosen above for each psychiatric disorder. In the case of MDE we are able to identify 176 individuals who do not meet diagnostic criteria but would be categorized as being depressed using a cutoff value of 0.2 . The number of individuals in this group for panic attack, social phobia and GAD is 19, 274 and 367 respectively. Identification of this group of individuals is important since they represent those who have some symptoms of the disorder and thus could potentially fare poorly in the labor market, but would not be captured using a binary indicator for meeting clinical diagnosis requirement. The distribution of the latent indices for these individuals closely resembles that of individuals who meet diagnostic requirements, further justifying our efforts to identify and include this group in an analysis examining the labor market effects of mental ill health (See Figure 1).

\section{Counterfactual policy simulations}

With the enactment of the Affordable Care Act, there will be a widespread expansion of coverage for mental health and substance use disorder services and provision of these services at parity with general medical and surgical care beginning in 2014 (Beronio et al. 2013). In the light of this policy change, it is important to analyze whether (i) the increase in access to mental health services would translate into greater utilization and subsequently effective treatment of mental disorders and, (ii) adequate treatment of disorders ultimately lead to improved labor market outcomes and broader inclusion of the mentally ill into the workplace. In this analysis we seek to address the second question.

\footnotetext{
${ }^{18}$ At these cutoff points for individual mental disorders we are also able to identify maximum number of individuals (results not shown) who do not meet the stringent requirement for meeting diagnostic criteria but are diagnosed as having the disorder according to our measure.
} 
We simulate the labor market outcomes for those who are in need of treatment (individuals diagnosed with a mental disorder in the past 12 months $\left.^{19}(D=1)\right)$ if they had the same symptom profile as those who do not require treatment (individuals not meeting diagnostic criteria for any mental disorder in the past 12 months $(D=0)^{20}$. In other words, we create a counterfactual group of $D=1$ individuals with identical profile of symptoms as $\mathrm{D}=0$ individuals and their original demographic, socio-economic and other health characteristics. In order to implement this we apply the "Rank and Replace" method used previously in research on health care disparities (McGuire et al. 2006; Cook et al. 2009, 2010). The procedure is outlined as follows: (i) Rank the $\mathrm{D}=1$ and $\mathrm{D}=0$ group individuals separately by their mental illness score $^{21}$ and obtain the percentile scores of the ranked individuals in each group, (ii) Rank the combined sample of $\mathrm{D}=1$ and $\mathrm{D}=0$ individuals in increasing order of their percentile scores previously computed. (iii) Replace the symptoms of $\mathrm{D}=1$ individual with symptoms of higher ranked (healthier) $\mathrm{D}=0$ individual, (iv) Using coefficients from previously estimated Model II (with 2 covariance instruments and 1 external instrument) obtain predicted value of labor market outcome with simulated mental health profile of $D=1$ individuals and original mental health profile of $D=0$ individuals. The above procedure is carried out separately for males and females.

In Table 14 we present results of the labor market benefits from improved mental health of the diagnosed individuals. We find a 15 percentage point increase in the likelihood of employment and 13 percentage point increase in the probability of labor force participation for males; and slightly lower 11 and 10 percentage point increases respectively for women. Further, males are predicted to work an additional two and a half weeks longer and females about one week more in a given year as a result of better mental health. We also conducted counterfactual simulations of the labor market effects of worsening mental health of undiagnosed individuals $(D=0)$, to match the symptom profile of diagnosed

\footnotetext{
${ }^{19}$ The disorders include MDE, panic attack, social phobia and GAD.

${ }^{20}$ We do not include those individuals from the $D=0$ group, whom we had identified as having a mental disorder even though they did not meet clinical diagnostic requirements (based on our concordance analysis), in the "need for treatment" group in order to provide conservative estimates of the labor market benefits from improved mental health.

${ }^{21}$ The mental illness score is computed from equations (3b) - (5b) in Model II.
} 
individuals $(D=1)$. We find substantial adverse impact of poor mental health on all the labor market outcomes and the magnitude of the effects are very similar to those obtained in Table 14 (see Table 15).

In order to put the individual level labor market effects into perspective, we calculate the societal impact of amelioration of mental health of the diagnosed group of individuals. We compute the gain in employment by using the number of individuals 24-64 years old who are in the labor force ${ }^{22}$ (BLS, 2002a), the prevalence rate of any mental disorder ${ }^{23}$ and the estimated increase in the likelihood of employment. We find that a total of 3.2 million individuals (1.59 million men and 1.57 million women) would gain employment from improved mental health. Further, we also calculate the workplace cost of absenteeism - this was carried out in two steps. First, we compute the monetary value of the lost work days in a year per person. We used the estimated value of the reduction in missed days due to improved mental health, obtained earlier, and the median weekly wages (following Greenberg et al. 1993) obtained from the Bureau of Labor Statistics (2002b). Second, we calculate the societal cost of absenteeism for the working age employed individuals. To this effect we use the employment figures for the 24-64 year old individuals (BLS 2002a) and the prevalence rate of any mental disorder. We find that the workplace cost of absenteeism is $\$ 18.9$ billion ( $\$ 14.4$ billion for men and a much lower $\$ 4.5$ billion for women) in 2002 dollars ${ }^{24}$.

\section{Discussion}

In this paper we have proposed an alternative methodological approach to examine the effect of mental disorders on labor market outcomes of individuals using latent indices for disorders. We believe this method is more nuanced and better able to capture heterogeneity in the manner in which psychiatric

\footnotetext{
${ }^{22}$ Here we assume that individuals who are out of the labor force do not reenter the labor force as a result of better mental health. This provides a conservative estimate of the increase in employment.

${ }^{23}$ The disorders considered are MDE, panic attack, social phobia and GAD. The prevalence rate is $16.75 \%$ for men and $26.11 \%$ for women, computed from our dataset.

${ }^{24}$ We use employment, labor force participation and median weekly wages data from BLS 2002 to arrive at the employment gain and societal cost estimates, since the NCS-R and the NLAAS was conducted between 2001 and 2003.
} 
disorders limit work functioning and lead to poor work outcomes. Our second contribution to the literature is obtaining identification without the use of exclusion restrictions, using an approach suggested in Lewbel (2012). Our results suggest that MDE and GAD detract from employment and labor force participation of males and females; however, we do not find evidence of adverse effect of panic attack or social phobia on any work outcomes of either males or females after controlling for comorbid psychiatric disorders. We also find evidence that poor mental health adversely affects the likelihood of being employed and labor force participation of both men and women. The effects are much larger across all model specifications after addressing the endogeneity of mental illness and the impact is greater for men compared to women. In case of the continuous work outcomes we find mental illness to reduce number of weeks worked and increase work absence for males only. Our findings also suggest that the indicators of MDE are most debilitating for work outcomes.

In order to relate our proposed measure with the standard binary indicator for mental disorder we conducted a concordance analysis. Based on two measures, the Peirce Score and the Odds Ratio, we find that the concomitance is highest at typically lower values on the latent scale for a psychiatric disorder. We are also able to identify a group of individuals who do not meet diagnostic criteria for a particular disorder but would be diagnosed as having the disorder in our analysis based on a chosen cutoff value. In the case of depression this group comprised 176 individuals - some of them failed to meet the requirement for having an episode for at least two weeks even though they had a number of symptoms of depression, some experienced the episode for longer than two weeks but did not meet the requirement for having at least 5 symptoms and so on. The inclusion of these individuals in an economic analysis of the causal effect of mental disorders on labor market outcomes is important from a policy perspective. If the goal of policy makers is to target employment they would need to explicitly focus attention and devote resources not only on those who meet requirements for clinical diagnosis, but also on individuals who have subclinical levels of a disorder which could limit their labor market opportunities and performance. 
One of the significant advantages of modeling mental health as a latent continuous measure and using symptoms of mental disorders to generate the latent mental health index is that we can examine the potential labor market benefits from enhanced and effective treatment of mental disorders by using counterfactual simulations. We find an increase in the likelihood of employment of 15 and 11 percentage points for men and women respectively, which is similar to the 11 percentage point increase for both men and women found in Ettner et al. (1997). We also calculate the workplace cost of absenteeism to be $\$ 18.9$ billion, which is much lower than $\$ 36.2$ billion found by Greenberg et al. (2003) for depression alone using the NCS-R. Greenberg et al.'s estimate, however, is not directly comparable with our finding since they do not examine the causal effect of depression on absenteeism, merely association between the two. In our counterfactual simulation exercise we have attempted to highlight some of the potential benefits from expanding access for mental health care benefits which have been proposed in the Affordable Care Act. A more thorough treatment, including direct costs of inpatient, outpatient and pharmaceutical costs and also other benefits in terms of improved productivity of treated individuals should be undertaken in future research to assess the cost effectiveness of the proposed changes for mental health and substance abuse disorder benefits. 


\section{References}

1. Alegria M, Takeuchi D, Canino G, Duan N, Shrout P, Meng X, Vega W, Zane N, Vila D, Woo M, Vera M, Guarnaccia P, Aguilar-Gaxiola S, Sue S, Escobar J, Lin K, Gong F. Considering Context, Place and Culture: The National Latino and Asian American Study. International Journal of Methods in Psychiatric Research 2004; 13(4): 208-220.

2. Altonji JG, Elder TE, Taber CR. Selection on Observed and Unobserved Variables: Assessing the effectiveness of Catholic Schools. Journal of Political Economy 2005; 113: 151-184.

3. Andrews G, Henderson S, Hall W. Prevalence, Comorbidity, disability and service utilisation: Overview of the Australian National Mental Health Survey. British Journal of Psychiatry 2001; 178: $145-153$.

4. Autor DH, Duggan MG. The Rise in the Disability Rolls and the Decline in Unemployment. The Quarterly Journal of Economics 2003; 118(1): 157-205.

5. Bartel A, Taubman P. Health and Labor Market Success: The Role of Various Diseases. The Review of Economics and Statistics 1979; 61(1): 1-8.

6. Bartel A, Taubman P. Some Economic and Demographic Consequences of Mental Illness. Journal of Labor Economics 1986; 4(2): 243-256.

7. Berndt ER, Finkelstein SN, Greenberg PE, Howland RH, Keith A, Rush AJ, Russell J, Keller MB. Workplace performance effects from chronic depression and its treatment. Journal of Health Economics 1998; 17: 511-535.

8. Beronio K, Po R, Skopec L, Glied S. Affordable Care Act Will Expand Mental Health and Substance Use Disorder Benefits and Parity Protections for 62 Million Americans. ASPE Research Brief, Department of Health and Human Services 2013: 1-4.

9. Breusch, T, and Pagan A. A Simple Test for Heteroscedasticity and Random Coefficient Variation. Econometrica 1979; 47(5):1287-1294.

10. Broadhead WE, Blazer DG, George LK, Tse CK. Depression, Disability Days, and Days Lost from Work in a Prospective Epidemiologic Survey. Journal of the American Medical Association 1990; 264(19): 2524-2528.

11. Bureau of Labor Statistics. Employment and earnings: Table 3: employment status of the civilian noninstitutional population by age, sex, and race. Washington, DC: US Dept. of Labor; 2002a. Available at: ftp://ftp.bls.gov/pub/special.requests/lf/aa2002/pdf/CPSAAT3.PDF.

12. Bureau of Labor Statistics. Highlights of women's earnings in 2002. Washington, DC: US Dept. of Labor; 2002b. Available at: http://stats.bls.gov/cps/cpswom2002.pdf. 
13. Chang H, Yen ST. Mental Health and Employment of the Elderly in Taiwan: A Simultaneous Equation Approach. Pacific Economic Review 2011; 16(4): 504-519.

14. Chatterji P, Alegria M, Lu M, Takeuchi D. Psychiatric disorders and labor market outcomes: Evidence from the National Latino and Asian American Study. Health Economics 2007; 16: 1069-1090.

15. Chatterji P, Alegria M, Takeuchi D. Psychiatric disorders and labor market outcomes: Evidence from the National Comorbidity Survey-Replication. Journal of Health Economics 2011; 30: 858868.

16. Cook BL, McGuire TG, Meara E, Zaslavsky AM. Adjusting for health status in non-linear models of health care disparities. Health Serv Outcomes Res Method 2009; 9:1-21.

17. Cook BL, McGuire TG, Lock K, Zaslavsky AM. Comparing Methods of Racial and Ethnic Disparities Measurement across Different Settings of Mental Health Care. Health Services Research 2010; 45(3): 825-847.

18. DeSimone J. Illegal Drug Use and Employment. Journal of Labor Economics 2002; 20(4): 952977.

19. Ettner SL, Frank RG, Kessler RC. The Impact of Psychiatric Disorders on Labor Market Outcomes. Industrial and Labor Relations Review 1997; 51(1): 64-81.

20. Frijters P, Johnston DW, Shields MA. Mental Health and Labor Market Participation: Evidence from IV Panel Data Models. Discussion Papers 2010; IZA DP No. 4883:1-26.

21. Goldberger AS. Structural Equation Models: An Overview. In: Goldberger AS, Duncan OD, eds. Structural Equation Models in the Social Sciences. New York: Seminar Press; 1973: 1-18.

22. Goldberger AS. Structural Equation Methods in the Social Sciences. Econometrica 1972; 40(6): 979-1001.

23. Greenberg PE, Stiglin LE, Finkelstein SN, Berndt ER. The Economic Burden of Depression in 1990. J Clin Psychiatry 1993; 54(11): 405-418.

24. Greenberg PE, Kessler RC, Birnbaum HG, Leong SA, Lowe SW, Berglund PA, Corey-Lisle PK. The Economic Burden of Depression in the United States: How Did It Change Between 1990 and 2000? J Clin Psychiatry 2003; 64(12): 1465-1475.

25. Hamilton VH, Merrigan P, Dufresne E. Down and Out: Estimating the Relationship between Mental Health and Unemployment. Health Economics 1997; 6: 397-406.

26. Hauser RM, Goldberger AS. The Treatment of Unobservable Variables in Path Analysis. Sociological Methodology 1971; 3: 81-117.

27. Hausman JA. Specification tests in Econometrics. Econometrica 1978; 46(6): 1251-1271. 
28. Heeringa SG, Wagner J, Torres M, Duan N, Adams T, Berglund P. Sample designs and sampling methods for the Collaborative Psychiatric Epidemiology Studies (CPES). International Journal of Methods in Psychiatric Research 2004; 13(4): 221-240.

29. Joreskog KG, Goldberger AS. Estimation of a Model with Multiple Indicators and Multiple Causes of a Single Latent Variable. Journal of the American Statistical Association 1975; 70(351): 631-639.

30. Kessler RC, Ustun TB. The World Mental Health (WMH) Survey Initiative Version of the World Health Organization (WHO) Composite International Diagnostic Interview (CIDI). Int J Methods Psychiatr Res 2004; 13(2): 93-121.

31. Kessler RC, Chiu WT, Demler O, Walters EE. Prevalence, Severity, and Comorbidity of 12Month DSM-IV Disorders in the National Comorbidity Survey Replication. Arch Gen Psychiatry 2005; 62: 617- 627.

32. Kessler RC, Heeringa S, Lakoma MD, Petukhova M, Rupp AE, Schoenbaum M, Wang PS, Zaslavsky AM. The individual-level and societal-level effects of mental disorders on earnings in the United States: Results from the National Comorbidity Survey Replication. Am J Psychiatry 2008; 165(6): 703-711.

33. Lahiri K, Vaughan DR, Wixon B. Modeling SSA's Sequential Disability Determination Process Using Matched SIPP Data. Social Security Bulletin 1995; 58(4): 3-42.

34. Lahiri K, Song J, Wixon B. A model of Social Security Disability Insurance using matched SIPP/Administrative Data. Journal of Econometrics 2008; 145: 4-20.

35. Lahiri K, Wang JG. Evaluating probability forecasts for GDP declines using alternative methodologies. International Journal of Forecasting 2013; 29(1): 175-190.

36. Lewbel A. Using Heteroscedasticity to Identify and Estimate Mismeasured and Endogenous Regressor Models. Journal of Business and Economic Statistics 2012; 30(1): 67-80.

37. Lu C, Frank RG, Liu Y, Shen J. The Impact of Mental Health on Labour Market Outcomes in China. The Journal of Mental Health Policy and Economics 2009; 12: 157-166.

38. McGuire TG, Alegria M, Cook BL, Wells KB, Zaslavsky AM. Implementing the Institute of Medicine Definition of Disparities: An Application to Mental Health Care. Health Services Research 2006; 41(5): 1979-2005.

39. Mitchell JM, Anderson KH. Mental Health and the Labor Force Participation of Older Workers. Inquiry 1989; 26: 262-271.

40. OECD. Sick on the Job? Myths and Realities about Mental Health and Work. Mental Health and Work, OECD Publishing 2011; http://dx.doi.org/10.1787/9789264124523-en. 
41. Ojeda VD, Frank RG, McGuire TG, Gilmer TP. Mental Illness, Nativity, Gender and Labor Supply. Health Economics 2010; 19: 396-421.

42. Renna F. Alcohol Abuse, Alcoholism, and Labor Market Outcomes: Looking for the Missing Link. Industrial and Labor Relations Review 2008; 62(1): 92-103. 


\begin{tabular}{|c|c|c|c|}
\hline Variables & Definition & $\begin{array}{c}\text { Male } \\
(\mathrm{N}=3331)\end{array}$ & $\begin{array}{c}\text { Female } \\
(\mathrm{N}=4235)\end{array}$ \\
\hline \multicolumn{4}{|l|}{ Labor Market outcomes } \\
\hline Employed & Binary variable $=1$ if respondent is employed (full-time or part-time) ; 0 otherwise & 0.84 & 0.69 \\
\hline In labor force & $\begin{array}{l}\text { Binary variable = } 1 \text { if respondent is in the labor force (employed or unemployed) ; } 0 \text { if not in the labor } \\
\text { force }\end{array}$ & 0.86 & 0.75 \\
\hline $\begin{array}{l}\text { Weeks worked in past year } \\
\text { conditional on employment }\end{array}$ & Number of weeks worked for pay or profit in past 12 months conditional on being employed & $50.46(0.20)$ & $49.41(0.19)$ \\
\hline $\begin{array}{l}\text { Days missed in past month } \\
\text { conditional on employment }\end{array}$ & Number of full days of work missed in past 30 days conditional on being employed & $1.08(0.13)$ & $1.22(0.10)$ \\
\hline \multicolumn{4}{|l|}{ Psychiatric disorders } \\
\hline $\begin{array}{l}\text { Any mental disorder in past } 12 \\
\text { months }\end{array}$ & $\begin{array}{l}\text { Binary variable }=1 \text { if respondent has any of the disorders: Major Depressive Episode, Dysthymia, } \\
\text { Agoraphobia, Generalized Anxiety Disorder, Panic Attack, Panic Disorder, Social Phobia, Alcohol Abuse, } \\
\text { Alcohol Dependence, Drug Abuse, Drug Dependence, Post-Traumatic Stress Disorder, Anorexia, Bulimia } \\
; 0 \text { otherwise }\end{array}$ & 0.2 & 0.29 \\
\hline \multicolumn{4}{|l|}{$\begin{array}{l}\text { Major Depressive Episode } \\
\text { indicators }\end{array}$} \\
\hline Depressed mood & $\begin{array}{l}\text { Binary variable }=1 \text { if felt depressed/ nothing could cheer you up/discouraged about things in life/ felt } \\
\text { hopeless about future most days during episode in past } 12 \text { months; } 0 \text { otherwise }\end{array}$ & 0.09 & 0.14 \\
\hline Diminished pleasure & $\begin{array}{l}\text { Binary variable }=1 \text { if nothing was fun even though good things were happening during episode in past } \\
12 \text { months; } 0 \text { otherwise }\end{array}$ & 0.08 & 0.12 \\
\hline Significant weight change & $\begin{array}{l}\text { Binary variable }=1 \text { if smaller appetite/ larger appetite than usual most days during episode in past } 12 \\
\text { months; } 0 \text { otherwise }\end{array}$ & 0.06 & 0.12 \\
\hline Insomnia or Hypersomnia & $\begin{array}{l}\text { Binary variable }=1 \text { if trouble sleeping/ sleeping more than usual most nights during episode in past } 12 \\
\text { months; } 0 \text { otherwise }\end{array}$ & 0.08 & 0.13 \\
\hline Restlessness or retardation & $\begin{array}{l}\text { Binary variable }=1 \text { if others notice talking/ moving more slowly/ restlessness during episode in past } 12 \\
\text { months; } 0 \text { otherwise }\end{array}$ & 0.05 & 0.07 \\
\hline Fatigue & $\begin{array}{l}\text { Binary variable }=1 \text { if low energy and tired without hard work most days during episode in past } 12 \\
\text { months; } 0 \text { otherwise }\end{array}$ & 0.07 & 0.13 \\
\hline Worthlessness & Binary variable $=1$ if feeling of worthlessness most days during episode in past 12 months; 0 otherwise & 0.04 & 0.07 \\
\hline Indecisiveness & $\begin{array}{l}\text { Binary variable }=1 \text { if slow or mixed up thoughts most days/ more trouble concentrating most days/ } \\
\text { unusual indecisiveness during episode in past } 12 \text { months; } 0 \text { otherwise }\end{array}$ & 0.08 & 0.13 \\
\hline Suicidal thoughts & $\begin{array}{l}\text { Binary variable }=1 \text { if often thought of death/ thought would be better if dead/ thought about suicide/ } \\
\text { made suicide plan/ attempted suicide during episode in past } 12 \text { months; } 0 \text { otherwise }\end{array}$ & 0.06 & 0.10 \\
\hline $\begin{array}{l}\text { Frequently severe emotional } \\
\text { distress }\end{array}$ & $\begin{array}{l}\text { Binary variable }=1 \text { if severe emotional distress often/ sometimes during episode in past } 12 \text { months; } 0 \\
\text { otherwise }\end{array}$ & 0.07 & 0.12 \\
\hline Severe emotional distress & $\begin{array}{l}\text { Binary variable }=1 \text { if moderate } / \text { severe/ very severe emotional distress during episode in past } 12 \\
\text { months; } 0 \text { otherwise }\end{array}$ & 0.08 & 0.13 \\
\hline Length of Depressive episode & Length of Depressive episode in days & $71.02(11.05)$ & $107.77(14.81)$ \\
\hline \multicolumn{4}{|l|}{ Panic Attack indicators } \\
\hline Sweating & Binary variable $=1$ if sweating during attack in past 12 months; 0 otherwise & 0.04 & 0.06 \\
\hline Trembling & Binary variable $=1$ if trembling/ shaking during attack in past 12 months; 0 otherwise & 0.03 & 0.05 \\
\hline Choking & Binary variable $=1$ if short of breath/ felt you were choking during attack in past 12 months; 0 otherwise & 0.05 & 0.10 \\
\hline Chest pain or nausea & $\begin{array}{l}\text { Binary variable }=1 \text { if chest pain/ discomfort or nausea/stomach discomfort during attack in past } 12 \\
\text { months; } 0 \text { otherwise }\end{array}$ & 0.05 & 0.09 \\
\hline Dizziness or unreality & $\begin{array}{l}\text { Binary variable }=1 \text { if felt dizzy/ felt you were not really there/ felt things around you unreal/ might lose } \\
\text { control or go crazy/ afraid might die / numbness or tingling/ hot flushes or chills during attack in past } 12 \\
\text { months; } 0 \text { otherwise }\end{array}$ & 0.05 & 0.09 \\
\hline \multicolumn{4}{|l|}{ Social Phobia indicators } \\
\hline Afraid meeting new people & Binary variable $=1$ if shy/afraid/uncomfortable meeting new people in past 12 months; 0 otherwise & 0.07 & 0.09 \\
\hline Afraid talking to authority & Binary variable $=1$ if shy/afraid/uncomfortable talking to authority in past 12 months; 0 otherwise & 0.06 & 0.09 \\
\hline Shy at social gathering & $\begin{array}{l}\text { Binary variable }=1 \text { if shy/afraid/uncomfortable at parties and social gatherings in past } 12 \text { months; } 0 \\
\text { otherwise }\end{array}$ & 0.06 & 0.08 \\
\hline Shy performing & $\begin{array}{l}\text { Binary variable }=1 \text { if shy/afraid/uncomfortable performing in front of audience in past } 12 \text { months; } 0 \\
\text { otherwise }\end{array}$ & 0.08 & 0.11 \\
\hline Shy of unknown people & $\begin{array}{l}\text { Binary variable }=1 \text { if shy/afraid/uncomfortable talking to people don't know well in past } 12 \text { months; } 0 \\
\text { otherwise }\end{array}$ & 0.06 & 0.08 \\
\hline Shy at disagreement & $\begin{array}{l}\text { Binary variable }=1 \text { if shy/afraid/uncomfortable disagreeing with people don't know well in past } 12 \\
\text { months; } 0 \text { otherwise }\end{array}$ & 0.05 & 0.08 \\
\hline Shy with others watching & $\begin{array}{l}\text { Binary variable }=1 \text { if shy/afraid/uncomfortable while writing/eating/drinking with someone watching in } \\
\text { past } 12 \text { months; } 0 \text { otherwise }\end{array}$ & 0.03 & 0.06 \\
\hline Shy using public restroom & Binary variable $=1$ if shy/afraid/uncomfortable using public bathroom in past 12 months; 0 otherwise & 0.03 & 0.04 \\
\hline Shy in dating situation & Binary variable $=1$ if shy/afraid/uncomfortable in dating situation in past 12 months; 0 otherwise & 0.05 & 0.06 \\
\hline
\end{tabular}


Uncomfortable getting attention Binary variable $=1$ if shy/afraid/uncomfortable being center of attention/ being in an embarrassing situation in past 12 months; 0 otherwise

Fear of embarrassment

Binary variable $=1$ if fear of embarrassment/humiliation/ fear of embarrassing others/ fear someone looking/talking / thinking negatively about you/ fear of being focus of attention in past 12 months; 0 otherwise

Fear of social situation

Avoid social situations

Social situations cause intense anxiety

Recent occurrence after age 18

Binary variable $=1$ if very upset/nervous in a social situation or in front of a group in past 12 months; 0 otherwise

Binary variable $=1$ if avoid social situation or activity in front of group due to fear in past 12 months; 0 otherwise

Binary variable $=1$ if respondent has 2 or more shyness reactions/ severe or very severe social fear if faced today/ fear of panic attack in past 12 months; 0 otherwise

Binary variable $=1$ if age of recent occurrence of feared/ avoided social situation is at least 18 years and it occurred in past 12 months; 0 otherwise

Generalized Anxiety Disorder

indicators

Excess anxiety

Length of GAD episode Difficult to control worry

Restlessness

Tired

Irritable

Difficulty concentrating

Tense muscles

Sleeping problems

Excessive nervousness

Significant emotional distress

Worry not always due to physical causes

Socio-demographic variables

Age

Age squared

Asian

Latino

Africanamerican

Married

Divorced

12 years of education

13-15 years of education

16 or more years of education

Midwest

South

West

Physical chronic conditions

Chronic conditions

Binary variable $=1$ if respondent worried more than others about same problems/ more

nervous/anxious than most with same problems / anxious/worried most days for one month or more in past 12 months; 0 otherwise

Length of episode when respondent was worried most days in past 12 months; 0 otherwise

Binary variable $=1$ if find hard to control worry/anxiousness/nervousness often/sometimes in past 12 months; 0 otherwise

Binary variable $=1$ if often feel restless, keyed up, or on edge in past 12 months; 0 otherwise

Binary variable $=1$ if often get tired easily in past 12 months; 0 otherwise

Binary variable $=1$ if often more irritable than usual in past 12 months; 0 otherwise

Binary variable $=1$ if often have difficulty concentrating or keeping ones mind on what one was doing in past 12 months; 0 otherwise

Binary variable $=1$ if often have tense, sore, or aching muscles in past 12 months; 0 otherwise

Binary variable $=1$ if often have trouble falling or staying asleep in past 12 months; 0 otherwise

Binary variable $=1$ if frequently so nervous that could not think of else regardless of effort in past 12 months; 0 otherwise

Binary variable $=1$ if worry/anxiety/nervousness cause moderate/ severe/ very severe distress in past 12 months; 0 otherwise

Binary variable $=1$ if worry/anxiousness/nervousness not always due to physical causes in past 12 months; 0 otherwise

Age of respondent

Squared age of respondent

Binary variable $=1$ if respondent is Asian (Vietnamese, Filipino, Chinese, all other Asians) ; 0 otherwise

Binary variable $=1$ if respondent is Latino ( Cuban, Puerto Rican, Mexican , all other Hispanic) ; 0

otherwise

Binary variable $=1$ if respondent is Africanamerican ; 0 otherwise

Binary variable $=1$ if married/cohabiting ; 0 otherwise

Binary variable $=1$ if divorced/ separated/ widowed ; 0 otherwise

Binary variable $=1$ if respondent had 12 years of education ; 0 otherwise

Binary variable $=1$ if respondent had 13 to 15 years of education ; 0 otherwise

Binary variable $=1$ if respondent had 16 or more years of education ; 0 otherwise

Binary variable $=1$ if region of residence is midwest $; 0$ otherwise

Binary variable $=1$ if region of residence is south $; 0$ otherwise

Binary variable $=1$ if region of residence is west ; 0 otherwise

Binary variable $=1$ if respondent had either Arthritis/Rheumatism , Stroke, Heart Attack, Diabetes, Ulcer or Cancer at any point in one's life ; 0 otherwise

Number of psychiatric disorders (Dysthymia , Major Depressive Disorder, Major Depressive Episode, Agoraphobia, Generalized Anxiety Disorder, Panic Attack, Panic Disorder, Post-Traumatic Stress Disorder, Social Phobia, Alcohol Abuse, Alcohol Dependence, Drug Abuse, Drug Dependence, Anorexia, Binge Eating Disorder, Bulimia, Intermittent Explosive Disorder ) with onset before age 18

Instrumental variable

disorders

$\begin{array}{cc}42.78(0.37) & 43.40(0.34) \\ 1937.31(31.38) & 1999.03(30.64) \\ 0.05 & 0.05 \\ & \\ 0.13 & 0.12 \\ & \\ 0.10 & 0.12 \\ 0.70 & 0.64 \\ 0.15 & 0.21 \\ 0.30 & 0.29 \\ 0.27 & 0.30 \\ 0.28 & 0.29 \\ 0.24 & 0.22 \\ 0.33 & 0.35 \\ 0.24 & 0.24 \\ & \\ 0.34 & 0.38 \\ & \\ 0.57(0.03) & 0.60(0.02)\end{array}$


Table 2. Effect of any mental disorder in past year on labor market outcomes for Males

\begin{tabular}{|c|c|c|c|c|c|c|c|c|}
\hline & \multicolumn{2}{|c|}{ Employed } & \multicolumn{2}{|c|}{ In labor force } & \multicolumn{2}{|c|}{$\begin{array}{l}\text { Weeks worked in past year } \\
\text { conditional on employment }\end{array}$} & \multicolumn{2}{|c|}{$\begin{array}{c}\text { Days missed in past } \\
\text { month conditional on } \\
\text { employment }\end{array}$} \\
\hline & $(1)$ & $(2)$ & (3) & (4) & (5) & $(6)$ & (7) & $(8)$ \\
\hline & Probit & $\begin{array}{c}\text { Bivariate } \\
\text { probit }\end{array}$ & Probit & $\begin{array}{c}\text { Bivariate } \\
\text { probit }\end{array}$ & OLS & $2 S L S$ & OLS & $2 S L S$ \\
\hline \multirow[t]{3}{*}{ Any mental disorder in past 12 months } & $-0.591 * * *$ & $-0.685 * * *$ & $-0.609 * * *$ & $-0.700 * * *$ & -0.672 & -1.804 & $0.479 *$ & 0.518 \\
\hline & $(0.085)$ & $(0.153)$ & $(0.090)$ & $(0.158)$ & $(0.446)$ & $(1.396)$ & $(0.286)$ & $(0.651)$ \\
\hline & [ -0.149] & {$[-0.177]$} & {$[-0.139]$} & {$[-0.164]$} & & & & \\
\hline \multirow[t]{2}{*}{ Age } & $0.068 * *$ & $0.068^{* *}$ & $0.063 * *$ & $0.064^{* *}$ & 0.272 & 0.275 & -0.089 & -0.089 \\
\hline & $(0.029)$ & $(0.029)$ & $(0.031)$ & $(0.031)$ & $(0.217)$ & $(0.214)$ & $(0.092)$ & $(0.092)$ \\
\hline \multirow[t]{2}{*}{ Age squared } & $-0.001 * * *$ & $-0.001 * * *$ & $-0.001 * * *$ & $-0.001 * * *$ & -0.003 & -0.003 & 0.001 & 0.001 \\
\hline & $(0.000)$ & $(0.000)$ & $(0.000)$ & $(0.000)$ & $(0.003)$ & $(0.002)$ & $(0.001)$ & $(0.001)$ \\
\hline \multirow[t]{2}{*}{ Asian } & $-0.304 * * *$ & $-0.314 * * *$ & $-0.179 * *$ & $-0.189 * *$ & 0.121 & 0.000 & -0.181 & -0.177 \\
\hline & $(0.096)$ & $(0.095)$ & $(0.090)$ & $(0.091)$ & $(0.580)$ & $(0.613)$ & $(0.280)$ & $(0.309)$ \\
\hline \multirow[t]{2}{*}{ Latino } & -0.139 & -0.143 & 0.105 & 0.102 & 0.143 & 0.097 & -0.220 & -0.219 \\
\hline & (0.101) & $(0.101)$ & $(0.118)$ & (0.119) & $(0.420)$ & $(0.432)$ & $(0.347)$ & $(0.358)$ \\
\hline \multirow[t]{2}{*}{ Africanamerican } & $-0.650 * * *$ & $-0.659 * * *$ & $-0.675 * * *$ & $-0.684 * * *$ & -1.482 & -1.571 & -0.195 & -0.192 \\
\hline & $(0.172)$ & $(0.171)$ & $(0.174)$ & $(0.173)$ & $(1.347)$ & $(1.333)$ & $(0.355)$ & $(0.371)$ \\
\hline \multirow[t]{2}{*}{ Married } & $0.375^{* * *}$ & $0.364 * * *$ & $0.407 * * *$ & $0.397 * * *$ & $2.868 * * *$ & $2.752 * *$ & 0.185 & 0.189 \\
\hline & $(0.114)$ & $(0.115)$ & $(0.117)$ & $(0.120)$ & $(1.072)$ & $(1.083)$ & (0.179) & $(0.178)$ \\
\hline \multirow[t]{2}{*}{ Divorced } & 0.237 & 0.236 & 0.265 & 0.264 & 2.056 & 2.021 & 0.843 & 0.844 \\
\hline & $(0.164)$ & $(0.164)$ & $(0.167)$ & $(0.168)$ & $(1.265)$ & $(1.252)$ & $(0.781)$ & $(0.775)$ \\
\hline \multirow[t]{2}{*}{12 years of education } & $0.459 * * *$ & $0.456 * * *$ & $0.485^{* * *}$ & $0.483 * * *$ & $1.434 * *$ & $1.407 * *$ & -0.534 & -0.534 \\
\hline & $(0.117)$ & (0.119) & $(0.117)$ & (0.119) & $(0.665)$ & $(0.670)$ & $(0.552)$ & $(0.553)$ \\
\hline \multirow[t]{2}{*}{$13-15$ years of education } & $0.645^{* * *}$ & $0.644 * * *$ & $0.678 * * *$ & $0.677^{* * *}$ & $1.060 * *$ & $1.029 * *$ & $-1.067^{*}$ & $-1.066^{*}$ \\
\hline & $(0.121)$ & $(0.122)$ & $(0.126)$ & $(0.128)$ & $(0.500)$ & $(0.504)$ & $(0.552)$ & $(0.556)$ \\
\hline \multirow[t]{2}{*}{16 or more years of education } & $0.634 * * *$ & $0.630 * * *$ & $0.689 * * *$ & $0.685^{* * *}$ & $1.285^{* *}$ & $1.260 * *$ & $-0.993 *$ & $-0.992 *$ \\
\hline & $(0.153)$ & $(0.154)$ & (0.159) & $(0.161)$ & $(0.596)$ & $(0.606)$ & $(0.509)$ & $(0.512)$ \\
\hline \multirow[t]{2}{*}{ Chronic conditions } & $-0.223 * *$ & $-0.213^{* *}$ & $-0.258 * * *$ & $-0.248 * *$ & -0.341 & -0.244 & 0.267 & 0.264 \\
\hline & $(0.092)$ & $(0.100)$ & $(0.094)$ & $(0.102)$ & $(0.350)$ & $(0.365)$ & $(0.264)$ & $(0.254)$ \\
\hline \multirow[t]{2}{*}{ Midwest } & -0.002 & -0.004 & -0.071 & -0.073 & 0.048 & 0.057 & 0.188 & 0.188 \\
\hline & $(0.124)$ & $(0.124)$ & $(0.132)$ & $(0.131)$ & $(0.344)$ & (0.339) & $(0.302)$ & $(0.304)$ \\
\hline \multirow[t]{2}{*}{ South } & 0.198 & 0.194 & 0.145 & 0.141 & 0.013 & -0.055 & 0.305 & 0.307 \\
\hline & $(0.120)$ & (0.119) & $(0.120)$ & (0.119) & $(0.427)$ & $(0.430)$ & $(0.250)$ & $(0.251)$ \\
\hline \multirow[t]{2}{*}{ West } & 0.043 & 0.042 & 0.041 & 0.040 & -1.318 & -1.325 & 0.533 & 0.533 \\
\hline & $(0.112)$ & $(0.112)$ & $(0.105)$ & $(0.104)$ & $(0.811)$ & $(0.805)$ & $(0.393)$ & $(0.392)$ \\
\hline \multirow[t]{2}{*}{$\rho$} & & 0.064 & & 0.061 & & & & \\
\hline & & $(0.101)$ & & $(0.105)$ & & & & \\
\hline$N$ & 3331 & 3331 & 3331 & 3331 & 2710 & 2710 & 2698 & 2698 \\
\hline
\end{tabular}


Table 3. Effect of any mental disorder in past year on labor market outcomes for Females

\begin{tabular}{|c|c|c|c|c|c|c|c|c|}
\hline & \multicolumn{2}{|c|}{ Employed } & \multicolumn{2}{|c|}{ In labor force } & \multicolumn{2}{|c|}{$\begin{array}{l}\text { Weeks worked in past year } \\
\text { conditional on employment }\end{array}$} & \multicolumn{2}{|c|}{$\begin{array}{l}\text { Days missed in past } \\
\text { month conditional on } \\
\text { employment }\end{array}$} \\
\hline & $(1)$ & $(2)$ & (3) & $(4)$ & (5) & (6) & (7) & (8) \\
\hline & Probit & $\begin{array}{c}\text { Bivariate } \\
\text { probit }\end{array}$ & Probit & $\begin{array}{c}\text { Bivariate } \\
\text { probit }\end{array}$ & OLS & $2 S L S$ & OLS & $2 S L S$ \\
\hline \multirow[t]{3}{*}{ Any mental disorder in past 12 months } & $-0.160 * * *$ & $-0.317 * *$ & $-0.167 * * *$ & $-0.333 * *$ & -0.304 & $-3.331 * *$ & $0.332^{*}$ & 0.642 \\
\hline & $(0.059)$ & $(0.131)$ & $(0.061)$ & $(0.151)$ & $(0.461)$ & $(1.381)$ & $(0.190)$ & $(0.511)$ \\
\hline & {$[-0.056]$} & {$[-0.11]$} & {$[-0.052]$} & {$[-0.107]$} & & & & \\
\hline \multirow[t]{2}{*}{ Age } & $0.162 * * *$ & $0.163^{* * *}$ & $0.090 * * *$ & $0.091 * * *$ & 0.183 & 0.221 & 0.007 & 0.003 \\
\hline & $(0.026)$ & $(0.026)$ & $(0.030)$ & $(0.030)$ & (0.159) & $(0.162)$ & $(0.084)$ & $(0.085)$ \\
\hline \multirow[t]{2}{*}{ Age squared } & $-0.002 * * *$ & $-0.002 * * *$ & $-0.001 * * *$ & $-0.001 * * *$ & -0.001 & -0.002 & -0.000 & -0.000 \\
\hline & $(0.000)$ & $(0.000)$ & $(0.000)$ & $(0.000)$ & $(0.002)$ & $(0.002)$ & $(0.001)$ & $(0.001)$ \\
\hline \multirow[t]{2}{*}{ Asian } & $-0.225^{* *}$ & $-0.251^{* *}$ & -0.174 & $-0.202^{*}$ & $1.156^{* * *}$ & 0.629 & $1.112^{* * *}$ & $1.165^{* * *}$ \\
\hline & $(0.108)$ & (0.109) & $(0.115)$ & $(0.118)$ & $(0.404)$ & $(0.484)$ & (0.298) & $(0.317)$ \\
\hline \multirow[t]{2}{*}{ Latino } & $-0.140 *$ & $-0.158 *$ & -0.137 & -0.156 & -0.400 & -0.793 & 0.278 & 0.318 \\
\hline & $(0.078)$ & $(0.082)$ & $(0.092)$ & $(0.098)$ & $(0.478)$ & $(0.493)$ & $(0.287)$ & $(0.305)$ \\
\hline \multirow[t]{2}{*}{ Africanamerican } & $-0.209 *$ & $-0.226 * *$ & $-0.215^{*}$ & $-0.233^{*}$ & 0.372 & 0.055 & 0.504 & 0.535 \\
\hline & $(0.110)$ & $(0.113)$ & $(0.125)$ & $(0.131)$ & $(0.654)$ & $(0.668)$ & $(0.500)$ & $(0.496)$ \\
\hline \multirow[t]{2}{*}{ Married } & -0.180 & -0.190 & -0.009 & -0.021 & $-1.244^{* *}$ & $-1.489 * * *$ & -0.513 & -0.490 \\
\hline & $(0.133)$ & $(0.136)$ & $(0.128)$ & $(0.131)$ & $(0.482)$ & $(0.485)$ & (0.507) & $(0.522)$ \\
\hline \multirow[t]{2}{*}{ Divorced } & 0.243 & 0.257 & $0.288^{*}$ & $0.303^{*}$ & -0.243 & -0.055 & -0.412 & -0.436 \\
\hline & $(0.166)$ & $(0.170)$ & $(0.155)$ & (0.158) & $(0.450)$ & $(0.471)$ & (0.533) & $(0.525)$ \\
\hline \multirow[t]{2}{*}{12 years of education } & $0.539 * * *$ & $0.528 * * *$ & $0.470 * * *$ & $0.458 * * *$ & 0.597 & 0.509 & -0.731 & -0.718 \\
\hline & $(0.094)$ & $(0.094)$ & $(0.093)$ & $(0.093)$ & $(0.538)$ & $(0.507)$ & $(0.631)$ & $(0.641)$ \\
\hline \multirow[t]{2}{*}{$13-15$ years of education } & $0.707^{* * *}$ & $0.695 * * *$ & $0.582 * * *$ & $0.570 * * *$ & 0.773 & 0.629 & $-1.131 *$ & $-1.116^{*}$ \\
\hline & $(0.097)$ & $(0.100)$ & (0.099) & (0.103) & $(0.555)$ & $(0.591)$ & $(0.643)$ & $(0.652)$ \\
\hline \multirow[t]{2}{*}{16 or more years of education } & $0.858 * * *$ & $0.841^{* * *}$ & $0.698 * * *$ & $0.680 * * *$ & 0.363 & 0.164 & -0.987 & -0.965 \\
\hline & (0.109) & $(0.115)$ & $(0.128)$ & $(0.136)$ & $(0.438)$ & $(0.435)$ & $(0.676)$ & $(0.689)$ \\
\hline \multirow[t]{2}{*}{ Chronic conditions } & $-0.205 * * *$ & $-0.184 * * *$ & $-0.221 * * *$ & $-0.199 * * *$ & -0.399 & -0.011 & 0.280 & 0.239 \\
\hline & $(0.072)$ & $(0.067)$ & $(0.080)$ & $(0.072)$ & $(0.421)$ & $(0.522)$ & $(0.231)$ & $(0.236)$ \\
\hline \multirow[t]{2}{*}{ Midwest } & $0.326 * * *$ & $0.322 * * *$ & $0.372 * * *$ & $0.368 * * *$ & $1.025 * *$ & 0.882 & -0.366 & -0.350 \\
\hline & (0.103) & (0.104) & $(0.086)$ & (0.088) & $(0.502)$ & $(0.551)$ & (0.368) & $(0.370)$ \\
\hline \multirow[t]{2}{*}{ South } & 0.092 & 0.092 & 0.137 & 0.138 & 0.396 & 0.383 & -0.324 & -0.320 \\
\hline & $(0.093)$ & (0.093) & $(0.102)$ & $(0.103)$ & $(0.605)$ & $(0.652)$ & $(0.386)$ & $(0.386)$ \\
\hline \multirow[t]{2}{*}{ West } & 0.042 & 0.040 & 0.060 & 0.058 & $-1.078^{* *}$ & $-1.109 * *$ & -0.225 & -0.219 \\
\hline & (0.106) & (0.107) & $(0.099)$ & (0.099) & (0.494) & $(0.520)$ & $(0.376)$ & $(0.375)$ \\
\hline \multirow[t]{2}{*}{$\rho$} & & 0.112 & & 0.118 & & & & \\
\hline & & $(0.092)$ & & (0.105) & & & & \\
\hline$N$ & 4235 & 4235 & 4235 & 4235 & 2815 & 2815 & 2779 & 2779 \\
\hline
\end{tabular}




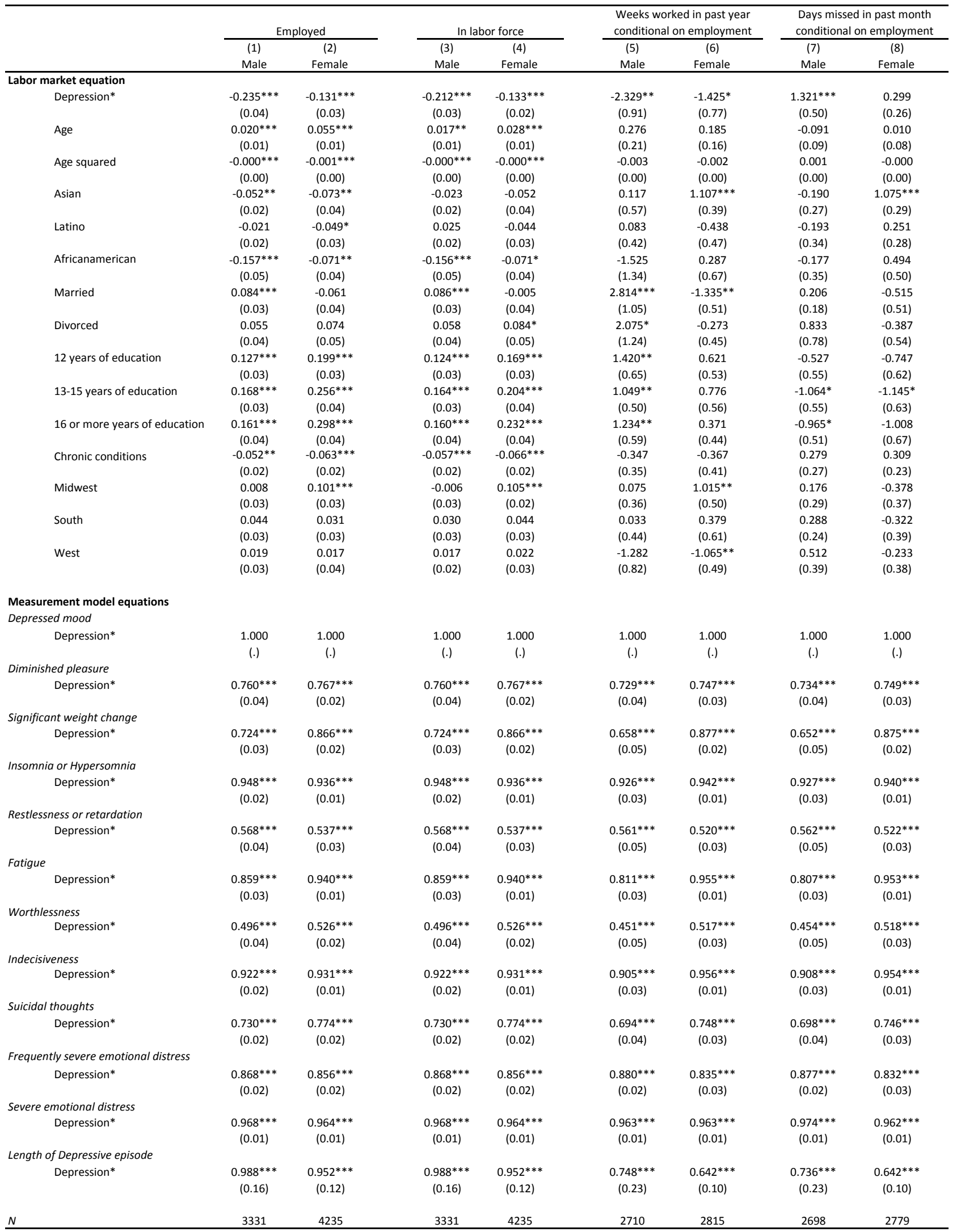

Notes: Standard errors in parentheses ; ${ }^{*} \mathrm{p}<0.10^{* *} \mathrm{p}<0.05^{* * *} \mathrm{p}<0.01$; Results are adjusted for complex survey design; Depression equation not reported for brevity; Length of Depressive episode indicator variable normalized to mean 0 and standard deviation 1 ; the coefficient on Depression* for the first equation of the measurement model is constrained to 1 as a normalization. 
Table 5: Model I : Effect of Panic Attack on labor market outcomes

\begin{tabular}{|c|c|c|c|c|c|c|c|c|}
\hline & \multicolumn{2}{|c|}{ Employed } & \multicolumn{2}{|c|}{ In labor force } & \multicolumn{2}{|c|}{$\begin{array}{l}\text { Weeks worked in past year } \\
\text { conditional on employment }\end{array}$} & \multicolumn{2}{|c|}{$\begin{array}{l}\text { Days missed in past month } \\
\text { conditional on employment }\end{array}$} \\
\hline & $(1)$ & $(2)$ & (3) & (4) & (5) & $(6)$ & (7) & $(8)$ \\
\hline & Male & Female & Male & Female & Male & Female & Male & Female \\
\hline \multicolumn{9}{|l|}{ Labor market equation } \\
\hline Panic Attack* & $\begin{array}{c}-0.319 * * \\
(0.14)\end{array}$ & $\begin{array}{c}-0.197^{* *} \\
(0.09)\end{array}$ & $\begin{array}{c}-0.319 * * \\
(0.14)\end{array}$ & $\begin{array}{c}-0.207 * * * \\
(0.08)\end{array}$ & $\begin{array}{c}-5.221^{*} \\
(3.09)\end{array}$ & $\begin{array}{l}0.442 \\
(1.12)\end{array}$ & $\begin{array}{l}0.537 \\
(0.68)\end{array}$ & $\begin{array}{l}0.934 \\
(0.64)\end{array}$ \\
\hline Age & $\begin{array}{c}0.019 * * \\
(0.01)\end{array}$ & $\begin{array}{c}0.055^{* * *} \\
(0.01)\end{array}$ & $\begin{array}{c}0.016^{* *} \\
(0.01)\end{array}$ & $\begin{array}{c}0.028^{* * *} \\
(0.01)\end{array}$ & $\begin{array}{l}0.263 \\
(0.22)\end{array}$ & $\begin{array}{l}0.178 \\
(0.16)\end{array}$ & $\begin{array}{l}-0.087 \\
(0.09)\end{array}$ & $\begin{array}{l}0.010 \\
(0.08)\end{array}$ \\
\hline Age squared & $\begin{array}{c}-0.000^{* * *} \\
(0.00)\end{array}$ & $\begin{array}{c}-0.001^{* * *} \\
(0.00)\end{array}$ & $\begin{array}{l}-0.000^{* * *} \\
(0.00)\end{array}$ & $\begin{array}{c}-0.000^{* * *} \\
(0.00)\end{array}$ & $\begin{array}{l}-0.003 \\
(0.00)\end{array}$ & $\begin{array}{r}-0.001 \\
(0.00)\end{array}$ & $\begin{array}{l}0.001 \\
(0.00)\end{array}$ & $\begin{array}{l}-0.000 \\
(0.00)\end{array}$ \\
\hline Asian & $\begin{array}{c}-0.050^{* *} \\
(0.02)\end{array}$ & $\begin{array}{c}-0.065^{*} \\
(0.04)\end{array}$ & $\begin{array}{l}-0.021 \\
(0.02)\end{array}$ & $\begin{array}{r}-0.044 \\
(0.04)\end{array}$ & $\begin{array}{l}0.113 \\
(0.57)\end{array}$ & $\begin{array}{c}1.219 * * * \\
(0.41)\end{array}$ & $\begin{array}{l}-0.223 \\
(0.27)\end{array}$ & $\begin{array}{c}1.075 * * * \\
(0.29)\end{array}$ \\
\hline Latino & $\begin{array}{l}-0.016 \\
(0.02)\end{array}$ & $\begin{array}{c}-0.046^{*} \\
(0.03)\end{array}$ & $\begin{array}{l}0.030 \\
(0.02)\end{array}$ & $\begin{array}{l}-0.041 \\
(0.03)\end{array}$ & $\begin{array}{l}0.125 \\
(0.41)\end{array}$ & $\begin{array}{l}-0.349 \\
(0.48)\end{array}$ & $\begin{array}{l}-0.236 \\
(0.34)\end{array}$ & $\begin{array}{l}0.260 \\
(0.28)\end{array}$ \\
\hline Africanamerican & $\begin{array}{c}-0.156^{* * *} \\
(0.05)\end{array}$ & $\begin{array}{c}-0.062^{*} \\
(0.04)\end{array}$ & $\begin{array}{c}-0.157^{* * *} \\
(0.05)\end{array}$ & $\begin{array}{l}-0.061 \\
(0.04)\end{array}$ & $\begin{array}{l}-1.572 \\
(1.36)\end{array}$ & $\begin{array}{l}0.410 \\
(0.66)\end{array}$ & $\begin{array}{l}-0.221 \\
(0.36)\end{array}$ & $\begin{array}{l}0.482 \\
(0.50)\end{array}$ \\
\hline Married & $\begin{array}{c}0.088^{* * *} \\
(0.03)\end{array}$ & $\begin{array}{l}-0.054 \\
(0.04)\end{array}$ & $\begin{array}{c}0.089 * * * \\
(0.03)\end{array}$ & $\begin{array}{l}0.002 \\
(0.04)\end{array}$ & $\begin{array}{c}2.740 * * * \\
(1.01)\end{array}$ & $\begin{array}{c}-1.212^{* *} \\
(0.50)\end{array}$ & $\begin{array}{l}0.155 \\
(0.19)\end{array}$ & $\begin{array}{l}-0.525 \\
(0.50)\end{array}$ \\
\hline Divorced & $\begin{array}{l}0.046 \\
(0.04)\end{array}$ & $\begin{array}{l}0.077 \\
(0.05)\end{array}$ & $\begin{array}{l}0.050 \\
(0.04)\end{array}$ & $\begin{array}{c}0.088^{*} \\
(0.05)\end{array}$ & $\begin{array}{c}1.914 \\
(1.22)\end{array}$ & $\begin{array}{l}-0.272 \\
(0.45)\end{array}$ & $\begin{array}{l}0.845 \\
(0.78)\end{array}$ & $\begin{array}{l}-0.412 \\
(0.54)\end{array}$ \\
\hline 12 years of education & $\begin{array}{c}0.127 * * * \\
(0.03)\end{array}$ & $\begin{array}{l}0.198^{* * *} \\
(0.03)\end{array}$ & $\begin{array}{l}0.124^{* * *} \\
(0.03)\end{array}$ & $\begin{array}{l}0.169 * * * \\
(0.03)\end{array}$ & $\begin{array}{c}1.348^{* *} \\
(0.67)\end{array}$ & $\begin{array}{l}0.615 \\
(0.54)\end{array}$ & $\begin{array}{l}-0.535 \\
(0.56)\end{array}$ & $\begin{array}{l}-0.722 \\
(0.63)\end{array}$ \\
\hline $13-15$ years of education & $\begin{array}{c}0.166^{* * *} \\
(0.03)\end{array}$ & $\begin{array}{c}0.255^{* * *} \\
(0.03)\end{array}$ & $\begin{array}{c}0.162 * * * \\
(0.03)\end{array}$ & $\begin{array}{c}0.203^{* * *} \\
(0.04)\end{array}$ & $\begin{array}{c}0.987^{* *} \\
(0.50)\end{array}$ & $\begin{array}{l}0.801 \\
(0.56)\end{array}$ & $\begin{array}{c}-1.070^{*} \\
(0.55)\end{array}$ & $\begin{array}{c}-1.116^{*} \\
(0.65)\end{array}$ \\
\hline 16 or more years of education & $\begin{array}{c}0.168^{* * *} \\
(0.04)\end{array}$ & $\begin{array}{c}0.297^{* * *} \\
(0.04)\end{array}$ & $\begin{array}{c}0.167^{* * *} \\
(0.04)\end{array}$ & $\begin{array}{c}0.231^{* * *} \\
(0.04)\end{array}$ & $\begin{array}{c}1.265^{* *} \\
(0.61)\end{array}$ & $\begin{array}{l}0.399 \\
(0.45)\end{array}$ & $\begin{array}{c}-0.998^{*} \\
(0.51)\end{array}$ & $\begin{array}{l}-0.975 \\
(0.67)\end{array}$ \\
\hline Chronic conditions & $\begin{array}{c}-0.054^{* * *} \\
(0.02)\end{array}$ & $\begin{array}{c}-0.067^{* * *} \\
(0.02)\end{array}$ & $\begin{array}{c}-0.058^{* * *} \\
(0.02)\end{array}$ & $\begin{array}{c}-0.069 * * * \\
(0.02)\end{array}$ & $\begin{array}{r}-0.267 \\
(0.36)\end{array}$ & $\begin{array}{l}-0.452 \\
(0.42)\end{array}$ & $\begin{array}{l}0.295 \\
(0.26)\end{array}$ & $\begin{array}{l}0.294 \\
(0.23)\end{array}$ \\
\hline Midwest & $\begin{array}{l}0.005 \\
(0.03)\end{array}$ & $\begin{array}{c}0.099 * * * \\
(0.03)\end{array}$ & $\begin{array}{r}-0.010 \\
(0.03)\end{array}$ & $\begin{array}{c}0.103^{* * *} \\
(0.02)\end{array}$ & $\begin{array}{l}0.068 \\
(0.35)\end{array}$ & $\begin{array}{c}1.044^{* *} \\
(0.49)\end{array}$ & $\begin{array}{l}0.190 \\
(0.30)\end{array}$ & $\begin{array}{l}-0.373 \\
(0.37)\end{array}$ \\
\hline South & 0.043 & 0.032 & 0.028 & 0.045 & 0.022 & 0.393 & 0.281 & -0.335 \\
\hline & $(0.03)$ & $(0.03)$ & $(0.02)$ & $(0.03)$ & $(0.43)$ & $(0.60)$ & $(0.25)$ & $(0.38)$ \\
\hline West & $\begin{array}{l}0.016 \\
(0.03)\end{array}$ & $\begin{array}{l}0.012 \\
(0.04)\end{array}$ & $\begin{array}{l}0.014 \\
(0.02)\end{array}$ & $\begin{array}{l}0.018 \\
(0.03)\end{array}$ & $\begin{array}{l}-1.293 \\
(0.82)\end{array}$ & $\begin{array}{c}-1.069 * * \\
(0.49)\end{array}$ & $\begin{array}{l}0.528 \\
(0.39)\end{array}$ & $\begin{array}{l}-0.219 \\
(0.38)\end{array}$ \\
\hline \multicolumn{9}{|l|}{ Sweating } \\
\hline Panic Attack* & $\begin{array}{c}1.000 \\
(.)\end{array}$ & $\begin{array}{c}1.000 \\
(.)\end{array}$ & $\begin{array}{c}1.000 \\
(.)\end{array}$ & $\begin{array}{c}1.000 \\
(.)\end{array}$ & $\begin{array}{c}1.000 \\
(.)\end{array}$ & $\begin{array}{c}1.000 \\
(.)\end{array}$ & $\begin{array}{c}1.000 \\
(.)\end{array}$ & $\begin{array}{c}1.000 \\
(.)\end{array}$ \\
\hline \multicolumn{9}{|l|}{ Trembling } \\
\hline Panic Attack* & $\begin{array}{c}0.504 * * * \\
(0.08)\end{array}$ & $\begin{array}{c}0.611^{* * *} \\
(0.10)\end{array}$ & $\begin{array}{c}0.504 * * * \\
(0.08)\end{array}$ & $\begin{array}{c}0.611^{* * *} \\
(0.10)\end{array}$ & $\begin{array}{c}0.660^{* * *} \\
(0.13)\end{array}$ & $\begin{array}{c}0.669 * * * \\
(0.10)\end{array}$ & $\begin{array}{c}0.662^{* * *} \\
(0.13)\end{array}$ & $\begin{array}{c}0.666 * * * \\
(0.10)\end{array}$ \\
\hline \multicolumn{9}{|l|}{ Choking } \\
\hline Panic Attack* & $\begin{array}{c}1.591^{* * *} \\
(0.19)\end{array}$ & $\begin{array}{c}1.873^{* * *} \\
(0.18)\end{array}$ & $\begin{array}{c}1.592 * * * \\
(0.19)\end{array}$ & $\begin{array}{c}1.873 * * * \\
(0.18)\end{array}$ & $\begin{array}{c}1.536 * * * \\
(0.27)\end{array}$ & $\begin{array}{c}1.514^{* * *} \\
(0.19)\end{array}$ & $\begin{array}{c}1.541^{* * *} \\
(0.28)\end{array}$ & $\begin{array}{c}1.531 * * * \\
(0.18)\end{array}$ \\
\hline \multicolumn{9}{|l|}{ Chest pain or nausea } \\
\hline Panic Attack* & $\begin{array}{c}1.294^{* * *} \\
(0.20)\end{array}$ & $\begin{array}{c}1.640 * * * \\
(0.19)\end{array}$ & $\begin{array}{c}1.294 * * * \\
(0.20)\end{array}$ & $\begin{array}{c}1.640 * * * \\
(0.19)\end{array}$ & $\begin{array}{c}1.267^{* * *} \\
(0.26)\end{array}$ & $\begin{array}{c}1.470 * * * \\
(0.16)\end{array}$ & $\begin{array}{c}1.265^{* * *} \\
(0.27)\end{array}$ & $\begin{array}{c}1.474^{* * *} \\
(0.17)\end{array}$ \\
\hline \multicolumn{9}{|l|}{ Dizziness or unreality } \\
\hline Panic Attack* & $\begin{array}{c}1.320 * * * \\
(0.19)\end{array}$ & $\begin{array}{c}1.590 * * * \\
(0.16)\end{array}$ & $\begin{array}{c}1.320 * * * \\
(0.19)\end{array}$ & $\begin{array}{c}1.590 * * * \\
(0.16)\end{array}$ & $\begin{array}{c}1.237^{* * *} \\
(0.20)\end{array}$ & $\begin{array}{c}1.388^{* * *} \\
(0.15)\end{array}$ & $\begin{array}{c}1.267^{* * *} \\
(0.21)\end{array}$ & $\begin{array}{c}1.402^{* * *} \\
(0.15)\end{array}$ \\
\hline$N$ & 3331 & 4235 & 3331 & 4235 & 2710 & 2815 & 2698 & 2779 \\
\hline
\end{tabular}

Notes: Standard errors in parentheses; ${ }^{*} \mathrm{p}<0.10^{* *} \mathrm{p}<0.05^{* * *} \mathrm{p}<0.01$; Results are adjusted for complex survey design; Panic Attack equation not reported for brevity;

the coefficient on Panic Attack* for the first equation of the measurement model is constrained to 1 as a normalization. 


\begin{tabular}{|c|c|c|c|c|c|c|c|c|}
\hline & \multicolumn{2}{|c|}{ Employed } & \multicolumn{2}{|c|}{ In labor force } & \multicolumn{2}{|c|}{$\begin{array}{l}\text { Weeks worked in past year } \\
\text { conditional on employment }\end{array}$} & \multicolumn{2}{|c|}{$\begin{array}{l}\text { Days missed in past month } \\
\text { conditional on employment }\end{array}$} \\
\hline & $\begin{array}{l}(1) \\
\text { Male }\end{array}$ & $\begin{array}{c}\text { (2) } \\
\text { Female }\end{array}$ & $\begin{array}{l}\text { (3) } \\
\text { Male }\end{array}$ & $\begin{array}{c}(4) \\
\text { Female }\end{array}$ & $\begin{array}{l}(5) \\
\text { Male }\end{array}$ & $\begin{array}{c}\text { (6) } \\
\text { Female }\end{array}$ & $\begin{array}{c}(7) \\
\text { Male }\end{array}$ & $\begin{array}{c}(8) \\
\text { Female }\end{array}$ \\
\hline \multicolumn{9}{|l|}{ Labor market equation } \\
\hline Social Phobia* & $\begin{array}{c}-0.149 * * * \\
(0.03)\end{array}$ & $\begin{array}{r}-0.041 \\
(0.04)\end{array}$ & $\begin{array}{c}-0.156^{* * *} \\
(0.03)\end{array}$ & $\begin{array}{l}-0.043 \\
(0.03)\end{array}$ & $\begin{array}{l}-1.561 \\
(0.99)\end{array}$ & $\begin{array}{l}-0.216 \\
(0.57)\end{array}$ & $\begin{array}{l}0.873^{*} \\
(0.45)\end{array}$ & $\begin{array}{l}0.330 \\
(0.39)\end{array}$ \\
\hline Age & $\begin{array}{c}0.019 * * * \\
(0.01)\end{array}$ & $\begin{array}{c}0.055^{* * *} \\
(0.01)\end{array}$ & $\begin{array}{c}0.016^{* *} \\
(0.01)\end{array}$ & $\begin{array}{c}0.028^{* * *} \\
(0.01)\end{array}$ & $\begin{array}{l}0.274 \\
(0.22)\end{array}$ & $\begin{array}{l}0.180 \\
(0.16)\end{array}$ & $\begin{array}{l}-0.089 \\
(0.09)\end{array}$ & $\begin{array}{l}0.009 \\
(0.08)\end{array}$ \\
\hline Age squared & $\begin{array}{c}-0.000 * * * \\
(0.00)\end{array}$ & $\begin{array}{c}-0.001 * * * \\
(0.00)\end{array}$ & $\begin{array}{c}-0.000 * * * \\
(0.00)\end{array}$ & $\begin{array}{c}-0.000^{* * *} \\
(0.00)\end{array}$ & $\begin{array}{l}-0.003 \\
(0.00)\end{array}$ & $\begin{array}{l}-0.001 \\
(0.00)\end{array}$ & $\begin{array}{l}0.001 \\
(0.00)\end{array}$ & $\begin{array}{l}-0.000 \\
(0.00)\end{array}$ \\
\hline Asian & $\begin{array}{c}-0.053^{* *} \\
(0.02)\end{array}$ & $\begin{array}{c}-0.064^{*} \\
(0.04)\end{array}$ & $\begin{array}{l}-0.025 \\
(0.02)\end{array}$ & $\begin{array}{l}-0.043 \\
(0.04)\end{array}$ & $\begin{array}{l}0.129 \\
(0.56)\end{array}$ & $\begin{array}{c}1.200^{* * *} \\
(0.41)\end{array}$ & $\begin{array}{l}-0.197 \\
(0.27)\end{array}$ & $\begin{array}{c}1.068^{* * *} \\
(0.29)\end{array}$ \\
\hline Latino & $\begin{array}{r}-0.020 \\
(0.02)\end{array}$ & $\begin{array}{c}-0.044^{*} \\
(0.03)\end{array}$ & $\begin{array}{l}0.025 \\
(0.02)\end{array}$ & $\begin{array}{l}-0.040 \\
(0.03)\end{array}$ & $\begin{array}{l}0.097 \\
(0.42)\end{array}$ & $\begin{array}{l}-0.372 \\
(0.49)\end{array}$ & $\begin{array}{l}-0.201 \\
(0.34)\end{array}$ & $\begin{array}{l}0.252 \\
(0.28)\end{array}$ \\
\hline Africanamerican & $\begin{array}{c}-0.152^{* * *} \\
(0.05)\end{array}$ & $\begin{array}{c}-0.060^{*} \\
(0.04)\end{array}$ & $\begin{array}{c}-0.153^{* * *} \\
(0.05)\end{array}$ & $\begin{array}{l}-0.060 \\
(0.04)\end{array}$ & $\begin{array}{l}-1.495 \\
(1.35)\end{array}$ & $\begin{array}{l}0.407 \\
(0.66)\end{array}$ & $\begin{array}{l}-0.198 \\
(0.35)\end{array}$ & $\begin{array}{l}0.465 \\
(0.50)\end{array}$ \\
\hline Married & $\begin{array}{c}0.093^{* * *} \\
(0.03)\end{array}$ & $\begin{array}{l}-0.052 \\
(0.04)\end{array}$ & $\begin{array}{c}0.094^{* * *} \\
(0.03)\end{array}$ & $\begin{array}{l}0.005 \\
(0.04)\end{array}$ & $\begin{array}{c}2.898^{* * *} \\
(1.06)\end{array}$ & $\begin{array}{c}-1.225^{* *} \\
(0.49)\end{array}$ & $\begin{array}{l}0.156 \\
(0.18)\end{array}$ & $\begin{array}{l}-0.528 \\
(0.50)\end{array}$ \\
\hline Divorced & $\begin{array}{l}0.054 \\
(0.04)\end{array}$ & $\begin{array}{l}0.073 \\
(0.05)\end{array}$ & $\begin{array}{l}0.057 \\
(0.04)\end{array}$ & $\begin{array}{l}0.083^{*} \\
(0.05)\end{array}$ & $\begin{array}{l}2.093^{*} \\
(1.26)\end{array}$ & $\begin{array}{l}-0.264 \\
(0.45)\end{array}$ & $\begin{array}{l}0.818 \\
(0.78)\end{array}$ & $\begin{array}{l}-0.386 \\
(0.54)\end{array}$ \\
\hline 12 years of education & $\begin{array}{c}0.131 * * * \\
(0.03)\end{array}$ & $\begin{array}{c}0.200^{* * *} \\
(0.04)\end{array}$ & $\begin{array}{c}0.129 * * * \\
(0.03)\end{array}$ & $\begin{array}{c}0.171^{* * *} \\
(0.03)\end{array}$ & $\begin{array}{c}1.447^{* *} \\
(0.67)\end{array}$ & $\begin{array}{l}0.594 \\
(0.54)\end{array}$ & $\begin{array}{l}-0.545 \\
(0.56)\end{array}$ & $\begin{array}{l}-0.726 \\
(0.64)\end{array}$ \\
\hline $13-15$ years of education & $\begin{array}{c}0.168^{* * *} \\
(0.03)\end{array}$ & $\begin{array}{c}0.259 * * * \\
(0.04)\end{array}$ & $\begin{array}{c}0.163^{* * *} \\
(0.03)\end{array}$ & $\begin{array}{c}0.207^{* * *} \\
(0.04)\end{array}$ & $\begin{array}{c}1.050^{* *} \\
(0.51)\end{array}$ & $\begin{array}{l}0.776 \\
(0.55)\end{array}$ & $\begin{array}{c}-1.065^{*} \\
(0.55)\end{array}$ & $\begin{array}{c}-1.128^{*} \\
(0.65)\end{array}$ \\
\hline 16 or more years of education & $\begin{array}{c}0.168^{* * *} \\
(0.04)\end{array}$ & $\begin{array}{c}0.302^{* * *} \\
(0.04)\end{array}$ & $\begin{array}{c}0.167 * * * \\
(0.04)\end{array}$ & $\begin{array}{c}0.236^{* * *} \\
(0.04)\end{array}$ & $\begin{array}{c}1.268^{* *} \\
(0.60)\end{array}$ & $\begin{array}{l}0.368 \\
(0.45)\end{array}$ & $\begin{array}{c}-0.984^{*} \\
(0.51)\end{array}$ & $\begin{array}{l}-0.987 \\
(0.68)\end{array}$ \\
\hline Chronic conditions & $\begin{array}{c}-0.061^{* * *} \\
(0.02)\end{array}$ & $\begin{array}{c}-0.071^{* * *} \\
(0.02)\end{array}$ & $\begin{array}{c}-0.064^{* * *} \\
(0.02)\end{array}$ & $\begin{array}{c}-0.074 * * * \\
(0.02)\end{array}$ & $\begin{array}{l}-0.382 \\
(0.35)\end{array}$ & $\begin{array}{l}-0.432 \\
(0.42)\end{array}$ & $\begin{array}{l}0.300 \\
(0.27)\end{array}$ & $\begin{array}{l}0.313 \\
(0.23)\end{array}$ \\
\hline Midwest & $\begin{array}{l}0.010 \\
(0.03)\end{array}$ & $\begin{array}{c}0.101^{* * *} \\
(0.03)\end{array}$ & $\begin{array}{l}-0.005 \\
(0.03)\end{array}$ & $\begin{array}{c}0.106^{* * *} \\
(0.02)\end{array}$ & $\begin{array}{l}0.079 \\
(0.35)\end{array}$ & $\begin{array}{c}1.037^{* *} \\
(0.50)\end{array}$ & $\begin{array}{l}0.175 \\
(0.29)\end{array}$ & $\begin{array}{l}-0.379 \\
(0.37)\end{array}$ \\
\hline South & $\begin{array}{l}0.045 \\
(0.03)\end{array}$ & $\begin{array}{l}0.032 \\
(0.03)\end{array}$ & $\begin{array}{l}0.031 \\
(0.03)\end{array}$ & $\begin{array}{l}0.045 \\
(0.03)\end{array}$ & $\begin{array}{l}0.043 \\
(0.42)\end{array}$ & $\begin{array}{l}0.399 \\
(0.60)\end{array}$ & $\begin{array}{l}0.285 \\
(0.24)\end{array}$ & $\begin{array}{l}-0.330 \\
(0.38)\end{array}$ \\
\hline West & $\begin{array}{l}0.019 \\
(0.03)\end{array}$ & $\begin{array}{l}0.017 \\
(0.04)\end{array}$ & $\begin{array}{l}0.016 \\
(0.02)\end{array}$ & $\begin{array}{l}0.023 \\
(0.03)\end{array}$ & $\begin{array}{l}-1.308 \\
(0.81)\end{array}$ & $\begin{array}{c}-1.072^{* *} \\
(0.49)\end{array}$ & $\begin{array}{l}0.528 \\
(0.39)\end{array}$ & $\begin{array}{l}-0.234 \\
(0.38)\end{array}$ \\
\hline \multicolumn{9}{|l|}{ Measurement model equations } \\
\hline \multicolumn{9}{|l|}{ Afraid meeting new people } \\
\hline Social Phobia* & $\begin{array}{l}1.000 \\
(.)\end{array}$ & $\begin{array}{l}1.000 \\
(.)\end{array}$ & $\begin{array}{c}1.000 \\
(.)\end{array}$ & $\begin{array}{l}1.000 \\
(.)\end{array}$ & $\begin{array}{l}1.000 \\
(.)\end{array}$ & $\begin{array}{c}1.000 \\
(.)\end{array}$ & $\begin{array}{c}1.000 \\
(.)\end{array}$ & $\begin{array}{l}1.000 \\
(.)\end{array}$ \\
\hline \multicolumn{9}{|l|}{ Afraid talking to authority } \\
\hline Social Phobia* & $\begin{array}{c}0.859^{* * *} \\
(0.04)\end{array}$ & $\begin{array}{c}0.925^{* * *} \\
(0.03)\end{array}$ & $\begin{array}{c}0.859^{* * *} \\
(0.04)\end{array}$ & $\begin{array}{c}0.925^{* * *} \\
(0.03)\end{array}$ & $\begin{array}{c}0.879 * * * \\
(0.05)\end{array}$ & $\begin{array}{c}0.966^{* * *} \\
(0.04)\end{array}$ & $\begin{array}{c}0.879 * * * \\
(0.05)\end{array}$ & $\begin{array}{c}0.955^{* * *} \\
(0.04)\end{array}$ \\
\hline \multicolumn{9}{|l|}{ Shy at social gathering } \\
\hline Social Phobia* & $\begin{array}{c}0.844^{* * *} \\
(0.03)\end{array}$ & $\begin{array}{c}0.840^{* * *} \\
(0.03)\end{array}$ & $\begin{array}{c}0.844^{* * *} \\
(0.03)\end{array}$ & $\begin{array}{c}0.840^{* * *} \\
(0.03)\end{array}$ & $\begin{array}{c}0.829 * * * \\
(0.05)\end{array}$ & $\begin{array}{c}0.852^{* * *} \\
(0.04)\end{array}$ & $\begin{array}{c}0.829 * * * \\
(0.05)\end{array}$ & $\begin{array}{c}0.853^{* * *} \\
(0.04)\end{array}$ \\
\hline \multicolumn{9}{|l|}{ Shy performing } \\
\hline Social Phobia* & $\begin{array}{c}1.078^{* * *} \\
(0.05)\end{array}$ & $\begin{array}{c}1.158^{* * *} \\
(0.04)\end{array}$ & $\begin{array}{c}1.078^{* * *} \\
(0.05)\end{array}$ & $\begin{array}{c}1.158^{* * *} \\
(0.04)\end{array}$ & $\begin{array}{c}1.147^{* * *} \\
(0.06)\end{array}$ & $\begin{array}{c}1.191^{* * *} \\
(0.05)\end{array}$ & $\begin{array}{c}1.147^{* * *} \\
(0.06)\end{array}$ & $\begin{array}{c}1.177^{* * *} \\
(0.05)\end{array}$ \\
\hline \multicolumn{9}{|l|}{ Shy of unknown people } \\
\hline Social Phobia* & $\begin{array}{c}0.809^{* * *} \\
(0.04)\end{array}$ & $\begin{array}{c}0.820^{* * *} \\
(0.02)\end{array}$ & $\begin{array}{c}0.809^{* * *} \\
(0.04)\end{array}$ & $\begin{array}{c}0.820^{* * *} \\
(0.02)\end{array}$ & $\begin{array}{c}0.808^{* * *} \\
(0.05)\end{array}$ & $\begin{array}{c}0.825^{* * *} \\
(0.03)\end{array}$ & $\begin{array}{c}0.808^{* * *} \\
(0.05)\end{array}$ & $\begin{array}{c}0.826^{* * *} \\
(0.03)\end{array}$ \\
\hline \multicolumn{9}{|l|}{ Shy at disagreement } \\
\hline Social Phobia* & $\begin{array}{c}0.664^{* * *} \\
(0.05)\end{array}$ & $\begin{array}{c}0.826 * * * \\
(0.04)\end{array}$ & $\begin{array}{c}0.664^{* * *} \\
(0.05)\end{array}$ & $\begin{array}{c}0.826^{* * *} \\
(0.04)\end{array}$ & $\begin{array}{c}0.638^{* * *} \\
(0.06)\end{array}$ & $\begin{array}{c}0.907^{* * *} \\
(0.04)\end{array}$ & $\begin{array}{c}0.638^{* * *} \\
(0.06)\end{array}$ & $\begin{array}{c}0.903^{* * *} \\
(0.04)\end{array}$ \\
\hline \multicolumn{9}{|l|}{ Shy with others watching } \\
\hline Social Phobia* & $\begin{array}{c}0.464^{* * *} \\
(0.03)\end{array}$ & $\begin{array}{c}0.630 * * * \\
(0.03)\end{array}$ & $\begin{array}{c}0.464^{* * *} \\
(0.03)\end{array}$ & $\begin{array}{c}0.630^{* * *} \\
(0.03)\end{array}$ & $\begin{array}{c}0.439 * * * \\
(0.05)\end{array}$ & $\begin{array}{c}0.624^{* * *} \\
(0.04)\end{array}$ & $\begin{array}{c}0.439 * * * \\
(0.05)\end{array}$ & $\begin{array}{c}0.615^{* * *} \\
(0.04)\end{array}$ \\
\hline \multicolumn{9}{|l|}{ Shy using public restroom } \\
\hline Social Phobia* & $\begin{array}{c}0.355^{* * *} \\
(0.05)\end{array}$ & $\begin{array}{c}0.403^{* * *} \\
(0.02)\end{array}$ & $\begin{array}{c}0.355^{* * *} \\
(0.05)\end{array}$ & $\begin{array}{c}0.403^{* * *} \\
(0.02)\end{array}$ & $\begin{array}{c}0.338^{* * *} \\
(0.05)\end{array}$ & $\begin{array}{c}0.364^{* * *} \\
(0.03)\end{array}$ & $\begin{array}{c}0.338^{* * *} \\
(0.05)\end{array}$ & $\begin{array}{c}0.365 * * * \\
(0.03)\end{array}$ \\
\hline \multicolumn{9}{|l|}{ Shy in dating situation } \\
\hline Social Phobia* & $\begin{array}{c}0.717^{* * *} \\
(0.04)\end{array}$ & $\begin{array}{c}0.679 * * * \\
(0.03)\end{array}$ & $\begin{array}{c}0.717^{* * *} \\
(0.04)\end{array}$ & $\begin{array}{c}0.679 * * * \\
(0.03)\end{array}$ & $\begin{array}{c}0.734^{* * *} \\
(0.04)\end{array}$ & $\begin{array}{c}0.690^{* * *} \\
(0.04)\end{array}$ & $\begin{array}{c}0.734 * * * \\
(0.04)\end{array}$ & $\begin{array}{c}0.686^{* * *} \\
(0.04)\end{array}$ \\
\hline \multicolumn{9}{|l|}{ Uncomfortable getting attention } \\
\hline Social Phobia* & $\begin{array}{c}0.924^{* * *} \\
(0.05)\end{array}$ & $\begin{array}{c}0.980^{* * *} \\
(0.04)\end{array}$ & $\begin{array}{c}0.924^{* * *} \\
(0.05)\end{array}$ & $\begin{array}{c}0.980 * * * \\
(0.04)\end{array}$ & $\begin{array}{c}0.968^{* * *} \\
(0.06)\end{array}$ & $\begin{array}{c}1.005^{* * *} \\
(0.05)\end{array}$ & $\begin{array}{c}0.968^{* * *} \\
(0.06)\end{array}$ & $\begin{array}{c}0.997^{* * *} \\
(0.05)\end{array}$ \\
\hline \multicolumn{9}{|l|}{ Fear of embarrassment } \\
\hline Social Phobia* & $\begin{array}{c}1.211^{* * *} \\
(0.05)\end{array}$ & $\begin{array}{c}1.243 * * * \\
(0.04)\end{array}$ & $\begin{array}{c}1.211^{* * *} \\
(0.05)\end{array}$ & $\begin{array}{c}1.243^{* * *} \\
(0.04)\end{array}$ & $\begin{array}{c}1.260^{* * *} \\
(0.07)\end{array}$ & $\begin{array}{c}1.284^{* * *} \\
(0.05)\end{array}$ & $\begin{array}{c}1.260^{* * *} \\
(0.07)\end{array}$ & $\begin{array}{c}1.270^{* * *} \\
(0.05)\end{array}$ \\
\hline \multicolumn{9}{|l|}{ Fear of social situation } \\
\hline Social Phobia* & $\begin{array}{c}1.164^{* * *} \\
(0.05)\end{array}$ & $\begin{array}{c}1.207^{* * *} \\
(0.04)\end{array}$ & $\begin{array}{c}1.164^{* * *} \\
(0.05)\end{array}$ & $\begin{array}{c}1.207^{* * *} \\
(0.04)\end{array}$ & $\begin{array}{c}1.190 * * * \\
(0.07)\end{array}$ & $\begin{array}{c}1.237^{* * *} \\
(0.05)\end{array}$ & $\begin{array}{c}1.190^{* * *} \\
(0.07)\end{array}$ & $\begin{array}{c}1.222^{* * *} \\
(0.05)\end{array}$ \\
\hline \multicolumn{9}{|l|}{ Avoid social situations } \\
\hline Social Phobia* & $\begin{array}{c}1.145^{* * *} \\
(0.05)\end{array}$ & $\begin{array}{c}1.153^{* * *} \\
(0.04)\end{array}$ & $\begin{array}{c}1.145^{* * *} \\
(0.05)\end{array}$ & $\begin{array}{c}1.153^{* * *} \\
(0.04)\end{array}$ & $\begin{array}{c}1.179 * * * \\
(0.06)\end{array}$ & $\begin{array}{c}1.176^{* * *} \\
(0.06)\end{array}$ & $\begin{array}{c}1.179 * * * \\
(0.06)\end{array}$ & $\begin{array}{c}1.164^{* * *} \\
(0.06)\end{array}$ \\
\hline \multicolumn{9}{|l|}{ Social situations cause intense anxiety } \\
\hline Social Phobia* & $\begin{array}{c}1.081^{* * *} \\
(0.06)\end{array}$ & $\begin{array}{c}1.130 * * * \\
(0.04)\end{array}$ & $\begin{array}{c}1.081^{* * *} \\
(0.06)\end{array}$ & $\begin{array}{c}1.130^{* * *} \\
(0.04)\end{array}$ & $\begin{array}{c}1.132^{* * *} \\
(0.08)\end{array}$ & $\begin{array}{c}1.150^{* * *} \\
(0.05)\end{array}$ & $\begin{array}{c}1.132^{* * *} \\
(0.08)\end{array}$ & $\begin{array}{c}1.136^{* * *} \\
(0.05)\end{array}$ \\
\hline Recent occurrence after age 18 & & & & & & & & \\
\hline Social Phobia* & $\begin{array}{c}1.244^{* * *} \\
(0.05)\end{array}$ & $\begin{array}{c}1.268^{* * *} \\
(0.03)\end{array}$ & $\begin{array}{c}1.244^{* * *} \\
(0.05)\end{array}$ & $\begin{array}{c}1.268^{* * *} \\
(0.03)\end{array}$ & $\begin{array}{c}1.293 * * * \\
(0.07)\end{array}$ & $\begin{array}{c}1.311^{* * *} \\
(0.05)\end{array}$ & $\begin{array}{c}1.293 * * * \\
(0.07)\end{array}$ & $\begin{array}{c}1.296^{* * *} \\
(0.05)\end{array}$ \\
\hline N & 3331 & 4235 & 3331 & 4235 & 2710 & 2815 & 2698 & 2779 \\
\hline
\end{tabular}




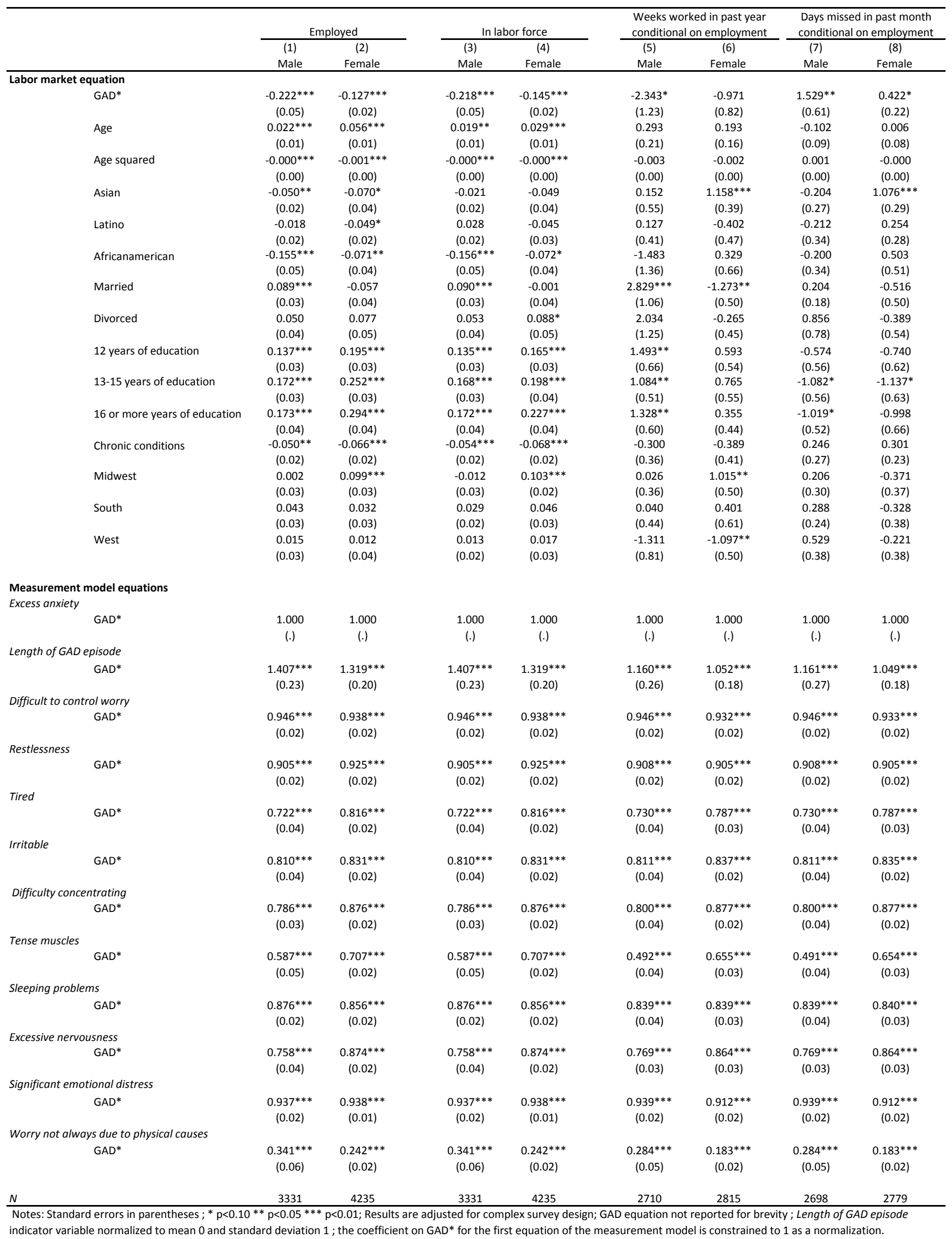




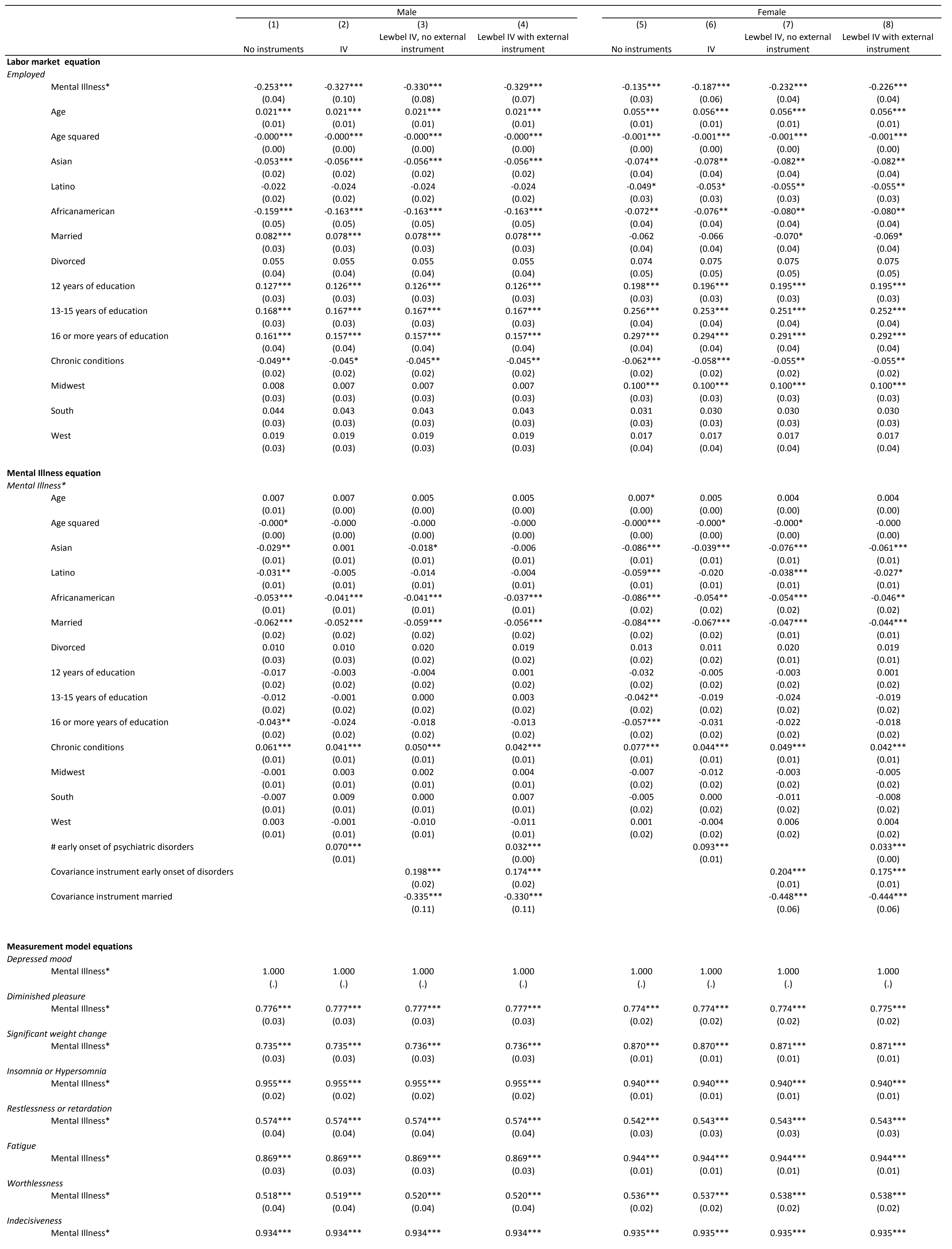




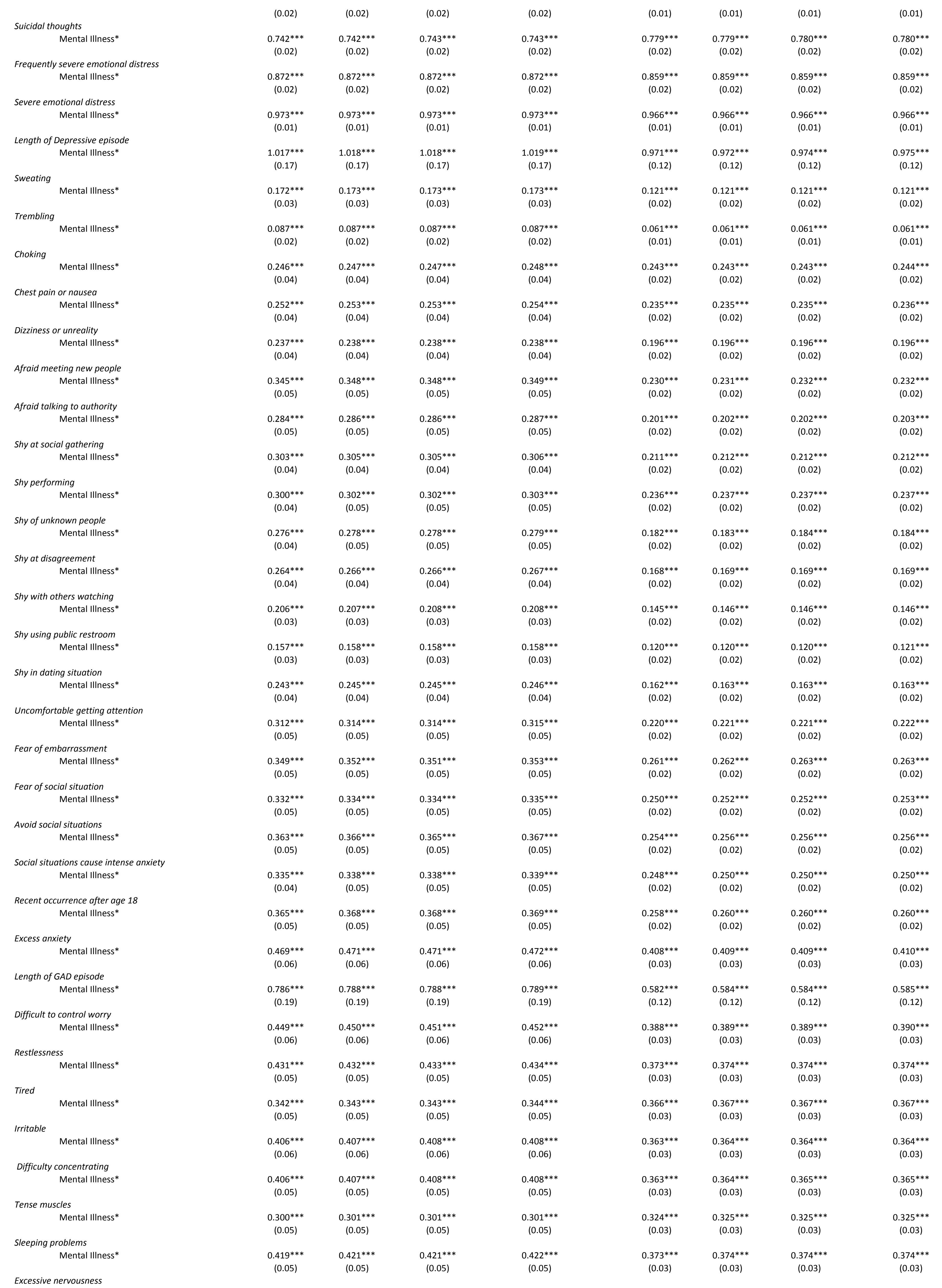


Mental Illness*

Significant emotional distress

Mental Illness*

Worry not always due to physical causes

Mental Illness*
$0.379^{* * *}$
$(0.04)$

$0.441^{* * *}$

$(0.06)$

$0.189 * * *$

$(0.04)$

Notes: Standard errors in parentheses,

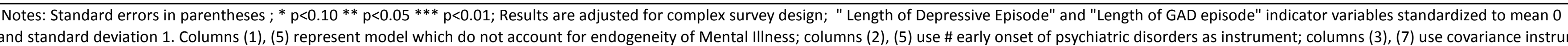
suggested by Lewbel (2012) ; columns (4), (8) use covariance instruments suggested by Lewbel (2012) and an external instrument : \# early onset of psychiatric disorders ; the coefficient on Mental Illness* for the first equation of the measurement model is constrained to 1 as a normalization. 


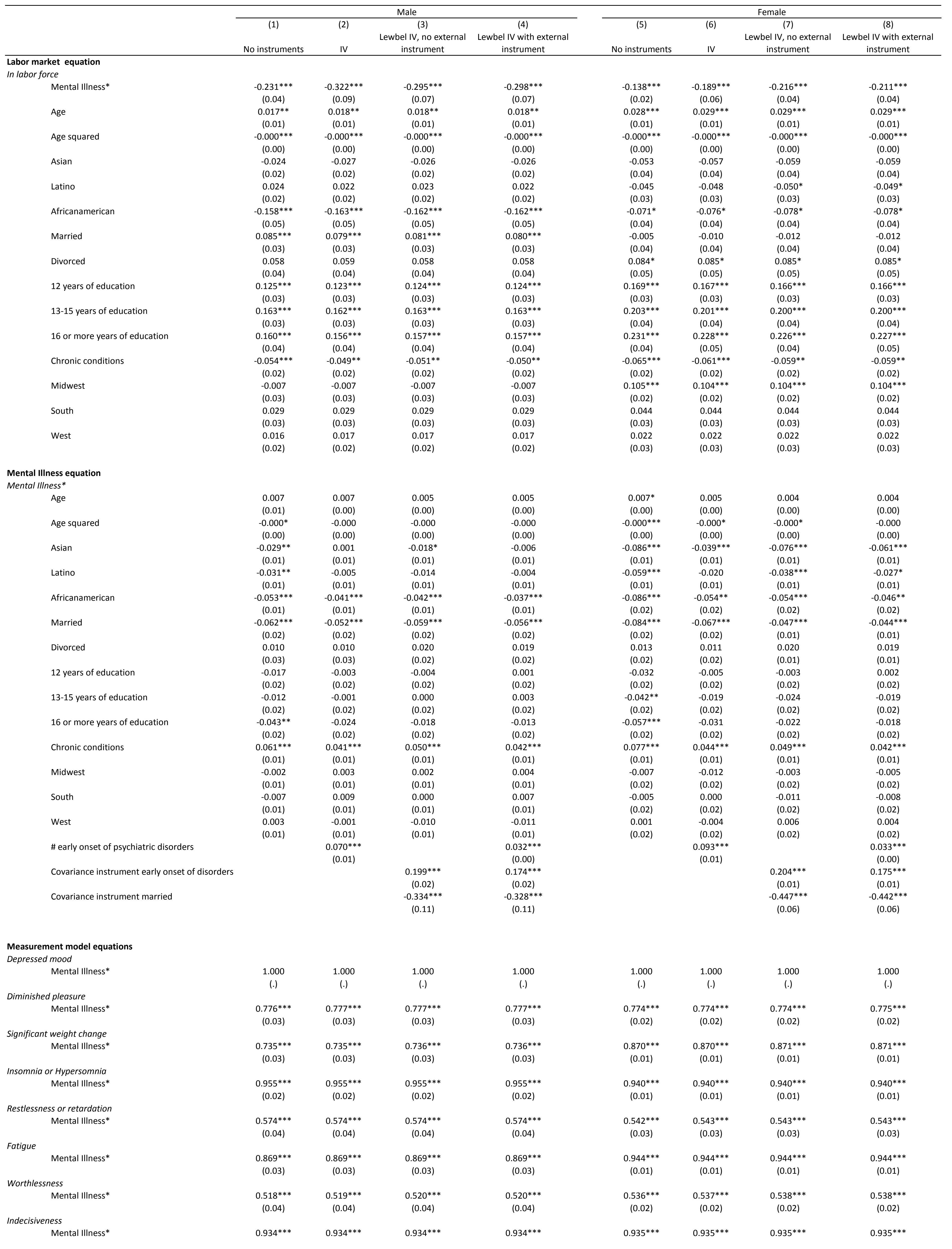




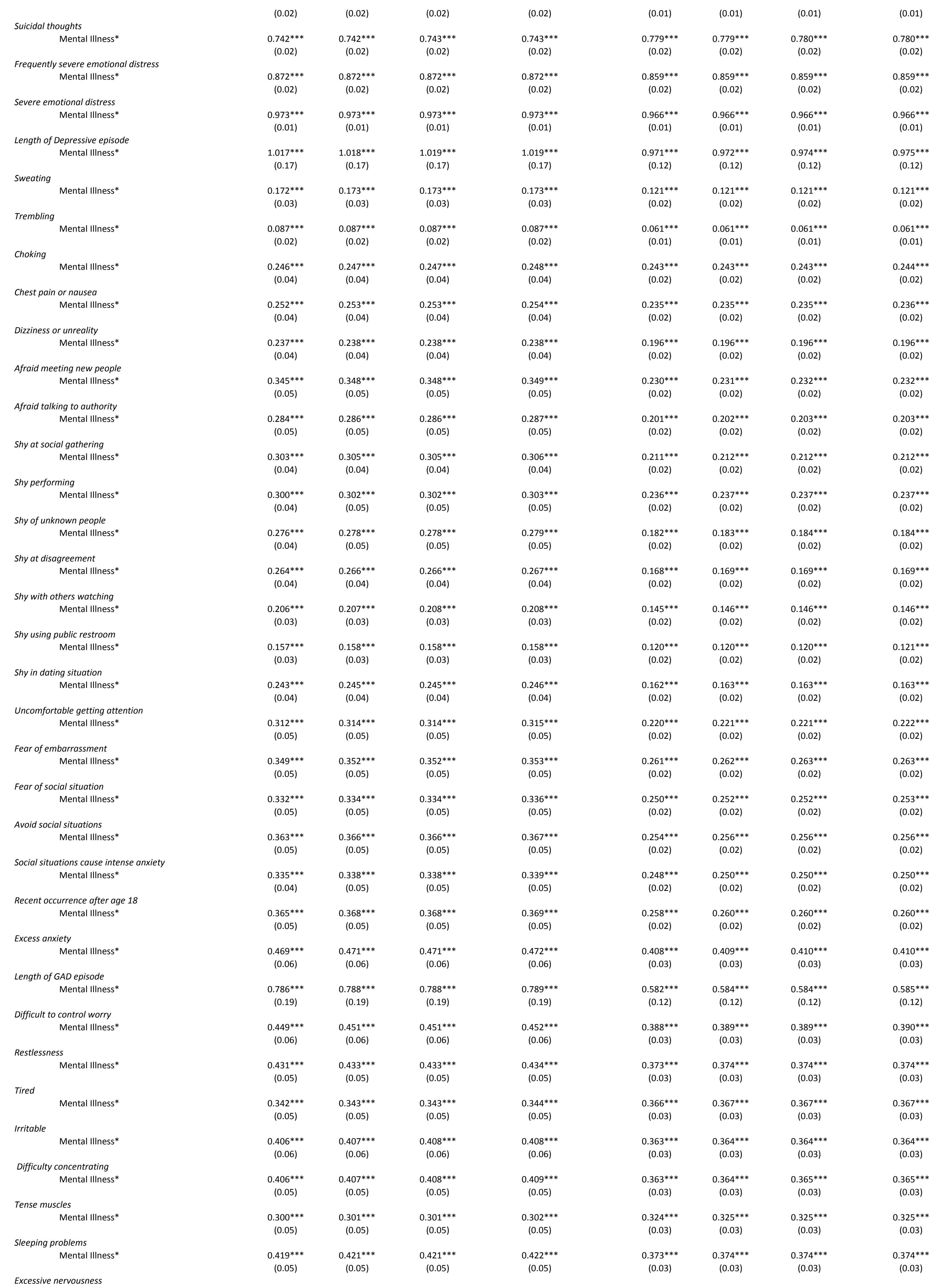


Mental Illness*

Significant emotional distress

Mental Illness*

Worry not always due to physical causes

Mental Illness*
$0.379^{* * *}$
$(0.04)$

$0.441^{* * *}$

$(0.06)$

$0.189 * * *$

$(0.04)$

Notes: Standard errors in parentheses,

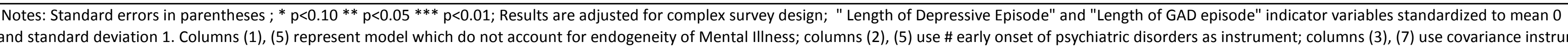
suggested by Lewbel (2012) ; columns (4), (8) use covariance instruments suggested by Lewbel (2012) and an external instrument : \# early onset of psychiatric disorders ; the coefficient on Mental Illness* for the first equation of the measurement model is constrained to 1 as a normalization. 
Table 10 : Model II : Effect of mental illness on number of weeks worked in past year conditional on being employed

\begin{tabular}{|c|c|c|c|c|c|c|c|c|}
\hline & \multicolumn{4}{|c|}{ Male } & \multicolumn{4}{|c|}{ Female } \\
\hline & $\begin{array}{c}(1) \\
\text { No instruments }\end{array}$ & $\begin{array}{l}\text { (2) } \\
\text { IV }\end{array}$ & $\begin{array}{c}(3) \\
\text { Lewbel IV, no external } \\
\text { instrument }\end{array}$ & $\begin{array}{c}(4) \\
\text { Lewbel IV with external } \\
\text { instrument }\end{array}$ & $\begin{array}{c}\text { (5) } \\
\text { No instruments }\end{array}$ & $\begin{array}{l}6) \\
\text { IV }\end{array}$ & $\begin{array}{c}(7) \\
\text { Lewbel IV, no external } \\
\text { instrument }\end{array}$ & $\begin{array}{c}(8) \\
\text { Lewbel IV with external } \\
\text { instrument }\end{array}$ \\
\hline \multicolumn{9}{|l|}{ Labor market equation } \\
\hline \multicolumn{9}{|l|}{ Weeks worked in past year conditional on employment } \\
\hline Mental Illness* & $\begin{array}{c}-2.558^{* *} \\
(1.04)\end{array}$ & $\begin{array}{l}-4.673 \\
(3.39)\end{array}$ & $\begin{array}{c}-6.846^{* *} \\
(3.08)\end{array}$ & $\begin{array}{c}-6.580^{* *} \\
(3.05)\end{array}$ & $\begin{array}{c}-1.449 * \\
(0.78)\end{array}$ & $\begin{array}{c}-6.579 * * * \\
(2.50)\end{array}$ & $\begin{array}{l}-1.357 \\
(1.52)\end{array}$ & $\begin{array}{l}-1.880 \\
(1.50)\end{array}$ \\
\hline Age & $\begin{array}{l}0.279 \\
(0.21)\end{array}$ & $\begin{array}{l}0.286 \\
(0.21)\end{array}$ & $\begin{array}{l}0.293 \\
(0.21)\end{array}$ & $\begin{array}{l}0.292 \\
(0.21)\end{array}$ & $\begin{array}{l}0.186 \\
(0.16)\end{array}$ & $\begin{array}{l}0.209 \\
(0.17)\end{array}$ & $\begin{array}{l}0.185 \\
(0.16)\end{array}$ & $\begin{array}{l}0.188 \\
(0.16)\end{array}$ \\
\hline Age squared & $\begin{array}{l}-0.003 \\
(0.00)\end{array}$ & $\begin{array}{l}-0.003 \\
(0.00)\end{array}$ & $\begin{array}{l}-0.003 \\
(0.00)\end{array}$ & $\begin{array}{r}-0.003 \\
(0.00)\end{array}$ & $\begin{array}{l}-0.002 \\
(0.00)\end{array}$ & $\begin{array}{l}-0.002 \\
(0.00)\end{array}$ & $\begin{array}{l}-0.002 \\
(0.00)\end{array}$ & $\begin{array}{l}-0.002 \\
(0.00)\end{array}$ \\
\hline Asian & $\begin{array}{l}0.104 \\
(0.57)\end{array}$ & $\begin{array}{l}0.031 \\
(0.61)\end{array}$ & $\begin{array}{l}-0.044 \\
(0.58)\end{array}$ & $\begin{array}{l}-0.035 \\
(0.59)\end{array}$ & $\begin{array}{c}1.102 * * * \\
(0.39)\end{array}$ & $\begin{array}{l}0.724 \\
(0.45)\end{array}$ & $\begin{array}{c}1.109 * * \\
(0.43)\end{array}$ & $\begin{array}{c}1.070^{* *} \\
(0.43)\end{array}$ \\
\hline Latino & $\begin{array}{l}0.070 \\
(0.42)\end{array}$ & $\begin{array}{l}-0.014 \\
(0.47)\end{array}$ & $\begin{array}{l}-0.099 \\
(0.44)\end{array}$ & $\begin{array}{l}-0.089 \\
(0.44)\end{array}$ & $\begin{array}{l}-0.443 \\
(0.47)\end{array}$ & $\begin{array}{l}-0.735 \\
(0.46)\end{array}$ & $\begin{array}{l}-0.438 \\
(0.49)\end{array}$ & $\begin{array}{l}-0.468 \\
(0.48)\end{array}$ \\
\hline Africanamerican & $\begin{array}{l}-1.542 \\
(1.34)\end{array}$ & $\begin{array}{l}-1.636 \\
(131)\end{array}$ & $\begin{array}{l}-1.732 \\
(1.32)\end{array}$ & $\begin{array}{l}-1.721 \\
(1.32)\end{array}$ & $\begin{array}{l}0.283 \\
(0.67)\end{array}$ & $\begin{array}{l}-0.147 \\
(0.72)\end{array}$ & $\begin{array}{l}0.291 \\
(0.69)\end{array}$ & $\begin{array}{l}0.247 \\
(0.69)\end{array}$ \\
\hline Married & $\begin{array}{c}2.795 * * * \\
(1.04)\end{array}$ & $\begin{array}{c}2.678^{* *} \\
(1.09)\end{array}$ & $\begin{array}{c}2.558^{* *} \\
(1.02)\end{array}$ & $\begin{array}{c}2.573^{* *} \\
(1.03)\end{array}$ & $\begin{array}{c}-1.340^{* * *} \\
(0.51)\end{array}$ & $\begin{array}{c}-1.767^{* * *} \\
(0.56)\end{array}$ & $\begin{array}{c}-1.332^{* * *} \\
(0.50)\end{array}$ & $\begin{array}{c}-1.375 * * * \\
(0.50)\end{array}$ \\
\hline Divorced & $\begin{array}{l}2.070^{*} \\
(1.24)\end{array}$ & $\begin{array}{c}2.063^{*} \\
(1.21)\end{array}$ & $\begin{array}{l}2.057^{*} \\
(1.19)\end{array}$ & $\begin{array}{l}2.057^{*} \\
(1.19)\end{array}$ & $\begin{array}{l}-0.273 \\
(0.45)\end{array}$ & $\begin{array}{l}-0.313 \\
(0.48)\end{array}$ & $\begin{array}{l}-0.273 \\
(0.45)\end{array}$ & $\begin{array}{l}-0.277 \\
(0.45)\end{array}$ \\
\hline 12 years of education & $\begin{array}{c}1.422^{* *} \\
(0.65)\end{array}$ & $\begin{array}{c}1.399^{* *} \\
(0.64)\end{array}$ & $\begin{array}{c}1.376^{* *} \\
(0.63)\end{array}$ & $\begin{array}{c}1.379^{* *} \\
(0.63)\end{array}$ & $\begin{array}{l}0.617 \\
(0.53)\end{array}$ & $\begin{array}{l}0.657 \\
(0.52)\end{array}$ & $\begin{array}{l}0.616 \\
(0.53)\end{array}$ & $\begin{array}{l}0.620 \\
(0.53)\end{array}$ \\
\hline $13-15$ years of education & $\begin{array}{c}1.045^{* *} \\
(0.50)\end{array}$ & $\begin{array}{c}1.016^{* *} \\
(0.50)\end{array}$ & $\begin{array}{c}0.987^{*} \\
(0.51)\end{array}$ & $\begin{array}{c}0.991^{*} \\
(0.51)\end{array}$ & $\begin{array}{l}0.772 \\
(0.56)\end{array}$ & $\begin{array}{l}0.717 \\
(0.57)\end{array}$ & $\begin{array}{l}0.773 \\
(0.56)\end{array}$ & $\begin{array}{l}0.767 \\
(0.56)\end{array}$ \\
\hline 16 or more years of education & $\begin{array}{c}1.230^{* *} \\
(0.59)\end{array}$ & $\begin{array}{l}1.172^{*} \\
(0.60)\end{array}$ & $\begin{array}{l}1.112^{*} \\
(0.59)\end{array}$ & $\begin{array}{l}1.120^{*} \\
(0.59)\end{array}$ & $\begin{array}{l}0.365 \\
(0.44)\end{array}$ & $\begin{array}{l}0.302 \\
(0.42)\end{array}$ & $\begin{array}{l}0.366 \\
(0.43)\end{array}$ & $\begin{array}{l}0.360 \\
(0.43)\end{array}$ \\
\hline Chronic conditions & $\begin{array}{l}-0.331 \\
(0.35)\end{array}$ & $\begin{array}{r}-0.275 \\
(0.35)\end{array}$ & $\begin{array}{l}-0.218 \\
(0.35)\end{array}$ & $\begin{array}{l}-0.225 \\
(0.35)\end{array}$ & $\begin{array}{l}-0.362 \\
(0.41)\end{array}$ & $\begin{array}{r}-0.091 \\
(0.48)\end{array}$ & $\begin{array}{l}-0.367 \\
(0.44)\end{array}$ & $\begin{array}{l}-0.339 \\
(0.44)\end{array}$ \\
\hline Midwest & $\begin{array}{l}0.076 \\
(0.36)\end{array}$ & $\begin{array}{l}0.104 \\
(0.38)\end{array}$ & $\begin{array}{l}0.132 \\
(0.40)\end{array}$ & $\begin{array}{l}0.128 \\
(0.40)\end{array}$ & $\begin{array}{c}1.013^{* *} \\
(0.50)\end{array}$ & $\begin{array}{l}0.917 \\
(0.56)\end{array}$ & $\begin{array}{c}1.014^{* *} \\
(0.50)\end{array}$ & $\begin{array}{c}1.005^{* *} \\
(0.50)\end{array}$ \\
\hline South & $\begin{array}{l}0.029 \\
(0.44)\end{array}$ & $\begin{array}{l}0.008 \\
(0.46)\end{array}$ & $\begin{array}{l}-0.014 \\
(0.48)\end{array}$ & $\begin{array}{l}-0.011 \\
(0.47)\end{array}$ & $\begin{array}{l}0.380 \\
(0.61)\end{array}$ & $\begin{array}{l}0.317 \\
(0.66)\end{array}$ & $\begin{array}{l}0.381 \\
(0.61)\end{array}$ & $\begin{array}{l}0.374 \\
(0.61)\end{array}$ \\
\hline West & $\begin{array}{l}-1.281 \\
(0.82)\end{array}$ & $\begin{array}{r}-1.254 \\
(0.84)\end{array}$ & $\begin{array}{l}-1.226 \\
(0.84)\end{array}$ & $\begin{array}{r}-1.229 \\
(0.84)\end{array}$ & $\begin{array}{c}-1.066^{* *} \\
(0.49)\end{array}$ & $\begin{array}{c}-1.036^{*} \\
(0.53)\end{array}$ & $\begin{array}{c}-1.067^{* *} \\
(0.50)\end{array}$ & $\begin{array}{c}-1.064^{* *} \\
(0.50)\end{array}$ \\
\hline Mental IIIness equation & & & & & & & & \\
\hline Mental IIIness* & & & & & & & & \\
\hline Age & $\begin{array}{l}0.003 \\
(0.01)\end{array}$ & $\begin{array}{l}0.003 \\
(0.01)\end{array}$ & $\begin{array}{l}0.001 \\
(0.01)\end{array}$ & $\begin{array}{l}0.001 \\
(0.01)\end{array}$ & $\begin{array}{l}0.005 \\
(0.00)\end{array}$ & $\begin{array}{l}0.003 \\
(0.00)\end{array}$ & $\begin{array}{l}0.002 \\
(0.00)\end{array}$ & $\begin{array}{l}0.002 \\
(0.00)\end{array}$ \\
\hline Age squared & $\begin{array}{l}-0.000 \\
(0.00)\end{array}$ & $\begin{array}{l}-0.000 \\
(0.00)\end{array}$ & $\begin{array}{l}-0.000 \\
(0.00)\end{array}$ & $\begin{array}{l}-0.000 \\
(0.00)\end{array}$ & $\begin{array}{c}-0.000^{*} \\
(0.00)\end{array}$ & $\begin{array}{l}-0.000 \\
(0.00)\end{array}$ & $\begin{array}{l}-0.000 \\
(0.00)\end{array}$ & $\begin{array}{l}-0.000 \\
(0.00)\end{array}$ \\
\hline Asian & $\begin{array}{c}-0.034^{* *} \\
(0.01)\end{array}$ & $\begin{array}{l}-0.015 \\
(0.01)\end{array}$ & $\begin{array}{c}-0.029 * * * \\
(0.01)\end{array}$ & $\begin{array}{c}-0.018^{* *} \\
(0.01)\end{array}$ & $\begin{array}{c}-0.074^{* * *} \\
(0.01)\end{array}$ & $\begin{array}{c}-0.038^{* *} \\
(0.02)\end{array}$ & $\begin{array}{c}-0.066^{* * *} \\
(0.01)\end{array}$ & $\begin{array}{c}-0.052^{* * * *} \\
(0.01)\end{array}$ \\
\hline Latino & $\begin{array}{c}-0.039 * * * \\
(0.01)\end{array}$ & $\begin{array}{c}-0.021^{*} \\
(0.01)\end{array}$ & $\begin{array}{c}-0.024^{*} \\
(0.01)\end{array}$ & $\begin{array}{l}-0.013 \\
(0.01)\end{array}$ & $\begin{array}{c}-0.057^{* * *} \\
(0.02)\end{array}$ & $\begin{array}{l}-0.025 \\
(0.02)\end{array}$ & $\begin{array}{c}-0.035 * * * \\
(0.01)\end{array}$ & $\begin{array}{c}-0.024^{*} \\
(0.01)\end{array}$ \\
\hline Africanamerican & $\begin{array}{c}-0.044^{* * *} \\
(0.01)\end{array}$ & $\begin{array}{c}-0.035^{* * *} \\
(0.01)\end{array}$ & $\begin{array}{c}-0.034^{* * *} \\
(0.01)\end{array}$ & $\begin{array}{c}-0.029^{* * *} \\
(0.01)\end{array}$ & $\begin{array}{c}-0.084^{* * *} \\
(0.02)\end{array}$ & $\begin{array}{c}-0.057^{* *} \\
(0.02)\end{array}$ & $\begin{array}{c}-0.056^{* * *} \\
(0.02)\end{array}$ & $\begin{array}{c}-0.047^{* *} \\
(0.02)\end{array}$ \\
\hline Married & $\begin{array}{c}-0.055^{* *} \\
(0.03)\end{array}$ & $\begin{array}{c}-0.049 * * \\
(0.02)\end{array}$ & $\begin{array}{c}-0.065^{* * *} \\
(0.02)\end{array}$ & $\begin{array}{c}-0.062^{* * *} \\
(0.02)\end{array}$ & $\begin{array}{c}-0.083^{* * *} \\
(0.02)\end{array}$ & $\begin{array}{c}-0.072^{* * *} \\
(0.02)\end{array}$ & $\begin{array}{c}-0.053^{* * *} \\
(0.01)\end{array}$ & $\begin{array}{c}-0.051^{* * * *} \\
(0.01)\end{array}$ \\
\hline Divorced & -0.003 & -0.001 & 0.012 & 0.012 & -0.008 & -0.005 & 0.021 & 0.020 \\
\hline & $(0.04)$ & $(0.03)$ & $(0.02)$ & $(0.02)$ & $(0.03)$ & $(0.03)$ & $(0.02)$ & $(0.02)$ \\
\hline 12 years of education & $\begin{array}{l}-0.011 \\
(0.02)\end{array}$ & $\begin{array}{l}-0.003 \\
(0.02)\end{array}$ & $\begin{array}{l}-0.003 \\
(0.02)\end{array}$ & $\begin{array}{l}0.001 \\
(0.02)\end{array}$ & $\begin{array}{l}0.008 \\
(0.02)\end{array}$ & $\begin{array}{l}0.021 \\
(0.02)\end{array}$ & $\begin{array}{l}0.017 \\
(0.02)\end{array}$ & $\begin{array}{l}0.020 \\
(0.02)\end{array}$ \\
\hline $13-15$ years of education & $\begin{array}{l}-0.013 \\
(0.02)\end{array}$ & $\begin{array}{l}-0.005 \\
(0.02)\end{array}$ & $\begin{array}{l}-0.004 \\
(0.02)\end{array}$ & $\begin{array}{l}0.000 \\
(0.02)\end{array}$ & $\begin{array}{l}-0.011 \\
(0.02)\end{array}$ & $\begin{array}{l}0.002 \\
(0.02)\end{array}$ & $\begin{array}{l}-0.011 \\
(0.02)\end{array}$ & $\begin{array}{l}-0.007 \\
(0.02)\end{array}$ \\
\hline 16 or more years of education & $\begin{array}{l}-0.028 \\
(0.02)\end{array}$ & $\begin{array}{l}-0.017 \\
(0.02)\end{array}$ & $\begin{array}{l}-0.013 \\
(0.02)\end{array}$ & $\begin{array}{l}-0.007 \\
(0.02)\end{array}$ & $\begin{array}{l}-0.012 \\
(0.02)\end{array}$ & $\begin{array}{l}-0.000 \\
(0.02)\end{array}$ & $\begin{array}{l}0.005 \\
(0.02)\end{array}$ & $\begin{array}{l}0.007 \\
(0.02)\end{array}$ \\
\hline Chronic conditions & $\begin{array}{c}0.026^{*} \\
(0.01)\end{array}$ & $\begin{array}{l}0.013 \\
(0.01)\end{array}$ & $\begin{array}{c}0.027^{* *} \\
(0.01)\end{array}$ & $\begin{array}{c}0.018^{*} \\
(0.01)\end{array}$ & $\begin{array}{c}0.053^{* * *} \\
(0.01)\end{array}$ & $\begin{array}{c}0.031^{* *} \\
(0.01)\end{array}$ & $\begin{array}{c}0.041^{* * *} \\
(0.01)\end{array}$ & $\begin{array}{c}0.035^{* * *} \\
(0.01)\end{array}$ \\
\hline Midwest & $\begin{array}{l}0.013 \\
(0.02)\end{array}$ & $\begin{array}{l}0.017 \\
(0.02)\end{array}$ & $\begin{array}{l}0.015 \\
(0.01)\end{array}$ & $\begin{array}{l}0.018 \\
(0.01)\end{array}$ & $\begin{array}{l}-0.019 \\
(0.03)\end{array}$ & $\begin{array}{l}-0.016 \\
(0.02)\end{array}$ & $\begin{array}{l}-0.006 \\
(0.02)\end{array}$ & $\begin{array}{l}-0.006 \\
(0.02)\end{array}$ \\
\hline South & -0.010 & 0.006 & 0.001 & 0.010 & -0.012 & -0.002 & -0.007 & -0.003 \\
\hline & $(0.02)$ & $(0.02)$ & $(0.01)$ & $(0.01)$ & $(0.03)$ & $(0.02)$ & $(0.02)$ & $(0.02)$ \\
\hline West & 0.013 & 0.015 & 0.005 & 0.007 & 0.006 & 0.004 & 0.008 & 0.007 \\
\hline & $(0.02)$ & $(0.02)$ & $(0.01)$ & $(0.01)$ & $(0.02)$ & $(0.02)$ & $(0.02)$ & $(0.02)$ \\
\hline \# early onset of psychiatric disorders & & $\begin{array}{c}0.050^{* * *} \\
(0.01)\end{array}$ & & $\begin{array}{c}0.031^{* * *} \\
(0.00)\end{array}$ & & $\begin{array}{c}0.075^{* * *} \\
(0.01)\end{array}$ & & $\begin{array}{c}0.029^{* * *} \\
(0.00)\end{array}$ \\
\hline Covariance instrument early onset of disorders & & & $\begin{array}{c}0.201 * * * \\
(0.03)\end{array}$ & $\begin{array}{c}0.185 * * * \\
(0.03)\end{array}$ & & & $\begin{array}{c}0.206 * * * \\
(0.01)\end{array}$ & $\begin{array}{c}0.183^{* * *} \\
(0.02)\end{array}$ \\
\hline Covariance instrument married & & & $-0.370^{* * *}$ & $-0.366^{* * *}$ & & & $-0.546^{* * *}$ & $-0.543^{* * *}$ \\
\hline & & & $(0.13)$ & $(0.13)$ & & & $(0.07)$ & $(0.07)$ \\
\hline Measurement model equations & & & & & & & & \\
\hline Depressed mood & & & & & & & & \\
\hline Mental IIIness* & $\begin{array}{c}1.000 \\
(.)\end{array}$ & $\begin{array}{l}1.000 \\
\text { (.) }\end{array}$ & $\begin{array}{c}1.000 \\
(.)\end{array}$ & $\begin{array}{l}1.000 \\
(.)\end{array}$ & $\begin{array}{c}1.000 \\
(.)\end{array}$ & $\begin{array}{l}1.000 \\
(.)\end{array}$ & $\begin{array}{l}1.000 \\
(.)\end{array}$ & $\begin{array}{l}1.000 \\
(.)\end{array}$ \\
\hline Diminished pleasure & & & & & & & & \\
\hline Mental Illness* & $\begin{array}{c}0.744^{* * *} \\
(0.04)\end{array}$ & $\begin{array}{c}0.744^{* * *} \\
(0.04)\end{array}$ & $\begin{array}{c}0.745^{* * *} \\
(0.04)\end{array}$ & $\begin{array}{c}0.745^{* * *} \\
(0.04)\end{array}$ & $\begin{array}{c}0.751^{* * *} \\
(0.03)\end{array}$ & $\begin{array}{c}0.751^{* * *} \\
(0.03)\end{array}$ & $\begin{array}{c}0.751^{* * *} \\
(0.03)\end{array}$ & $\begin{array}{c}0.751^{* * *} \\
(0.03)\end{array}$ \\
\hline Significant weight change & & & & & & & & \\
\hline Mental Illness* & $\begin{array}{c}0.666^{* * *} \\
(0.05)\end{array}$ & $\begin{array}{c}0.666^{* * *} \\
(0.05)\end{array}$ & $\begin{array}{c}0.667^{* * *} \\
(0.05)\end{array}$ & $\begin{array}{c}0.667^{* * *} \\
(0.05)\end{array}$ & $\begin{array}{c}0.879^{* * *} \\
(0.02)\end{array}$ & $\begin{array}{c}0.879^{* * *} \\
(0.02)\end{array}$ & $\begin{array}{c}0.879^{* * *} \\
(0.02)\end{array}$ & $\begin{array}{c}0.879^{* * *} \\
(0.02)\end{array}$ \\
\hline Insomnia or Hypersomnia & & & & & & & & \\
\hline Mental Illness* & $\begin{array}{c}0.932^{* * *} \\
(0.03)\end{array}$ & $\begin{array}{c}0.932 * * * \\
(0.03)\end{array}$ & $\begin{array}{c}0.932^{* * *} \\
(0.03)\end{array}$ & $\begin{array}{c}0.933^{* * *} \\
(0.03)\end{array}$ & $\begin{array}{c}0.945^{* * *} \\
(0.01)\end{array}$ & $\begin{array}{c}0.945 * * * \\
(0.01)\end{array}$ & $\begin{array}{c}0.945^{* * *} \\
(0.01)\end{array}$ & $\begin{array}{c}0.945^{* * *} \\
(0.01)\end{array}$ \\
\hline Restlessness or retardation & & & & & & & & \\
\hline Mental Illness* & $\begin{array}{c}0.567^{* * *} \\
(0.05)\end{array}$ & $\begin{array}{c}0.567^{* * *} \\
(0.05)\end{array}$ & $\begin{array}{c}0.567^{* * *} \\
(0.05)\end{array}$ & $\begin{array}{c}0.568^{* * *} \\
(0.05)\end{array}$ & $\begin{array}{c}0.523 * * * \\
(0.03)\end{array}$ & $\begin{array}{c}0.523 * * * \\
(0.03)\end{array}$ & $\begin{array}{c}0.523 * * * \\
(0.03)\end{array}$ & $\begin{array}{c}0.523 * * * \\
(0.03)\end{array}$ \\
\hline Fatigue & & & & & & & & \\
\hline Mental Illness* & $\begin{array}{c}0.818^{* * *} \\
(0.04)\end{array}$ & $\begin{array}{c}0.818^{* * *} \\
(0.04)\end{array}$ & $\begin{array}{c}0.818^{* * *} \\
(0.04)\end{array}$ & $\begin{array}{c}0.818^{* * *} \\
(0.04)\end{array}$ & $\begin{array}{c}0.957^{* * *} \\
(0.01)\end{array}$ & $\begin{array}{c}0.957^{* * *} \\
(0.01)\end{array}$ & $\begin{array}{c}0.957^{* * *} \\
(0.01)\end{array}$ & $\begin{array}{c}0.957^{* * *} \\
(0.01)\end{array}$ \\
\hline Worthlessness & & & & & & & & \\
\hline Mental Illness* & $\begin{array}{c}0.468^{* * *} \\
(0.05)\end{array}$ & $\begin{array}{c}0.468^{* * *} \\
(0.05)\end{array}$ & $\begin{array}{c}0.469^{* * *} \\
(0.05)\end{array}$ & $\begin{array}{c}0.470^{* * *} \\
(0.05)\end{array}$ & $\begin{array}{c}0.523 * * * \\
(0.03)\end{array}$ & $\begin{array}{c}0.523 * * * \\
(0.03)\end{array}$ & $\begin{array}{c}0.524^{* * *} \\
(0.03)\end{array}$ & $\begin{array}{c}0.524^{* * *} \\
(0.03)\end{array}$ \\
\hline Indecisiveness & & & & & & & & \\
\hline Mental Illness* & $0.915^{* * *}$ & $0.915 * * *$ & $0.916 * * *$ & $0.916^{* * *}$ & $0.958^{* * *}$ & $0.958^{* * *}$ & $0.958^{* * *}$ & $0.958^{* * *}$ \\
\hline
\end{tabular}




\begin{tabular}{|c|c|c|c|c|c|c|c|c|}
\hline & $(0.03)$ & $(0.03)$ & $(0.03)$ & $(0.03)$ & $(0.01)$ & $(0.01)$ & $(0.01)$ & $(0.01)$ \\
\hline \multicolumn{9}{|l|}{ Suicidal thoughts } \\
\hline Mental Illness* & $\begin{array}{c}0.707^{* * *} \\
(0.04)\end{array}$ & $\begin{array}{c}0.707^{* * *} \\
(0.04)\end{array}$ & $\begin{array}{c}0.708^{* * *} \\
(0.04)\end{array}$ & $\begin{array}{c}0.708^{* * *} \\
(0.04)\end{array}$ & $\begin{array}{c}0.750^{* * *} \\
(0.03)\end{array}$ & $\begin{array}{c}0.750^{* * *} \\
(0.03)\end{array}$ & $\begin{array}{c}0.750^{* * *} \\
(0.03)\end{array}$ & $\begin{array}{c}0.750^{* * *} \\
(0.03)\end{array}$ \\
\hline \multicolumn{9}{|c|}{ Frequently severe emotional distress } \\
\hline Mental IIIness* & $\begin{array}{c}0.885^{* * *} \\
(0.02)\end{array}$ & $\begin{array}{c}0.885^{* * *} \\
(0.02)\end{array}$ & $\begin{array}{c}0.885^{* * *} \\
(0.02)\end{array}$ & $\begin{array}{c}0.886^{* * *} \\
(0.02)\end{array}$ & $\begin{array}{c}0.837^{* * *} \\
(0.03)\end{array}$ & $\begin{array}{c}0.837^{* * *} \\
(0.03)\end{array}$ & $\begin{array}{c}0.837^{* * *} \\
(0.03)\end{array}$ & $\begin{array}{c}0.837^{* * *} \\
(0.03)\end{array}$ \\
\hline \multicolumn{9}{|l|}{ Severe emotional distress } \\
\hline Mental Illness* & $\begin{array}{c}0.967^{* * *} \\
(0.01)\end{array}$ & $\begin{array}{c}0.967^{* * *} \\
(0.01)\end{array}$ & $\begin{array}{c}0.968^{* * *} \\
(0.01)\end{array}$ & $\begin{array}{c}0.968^{* * *} \\
(0.01)\end{array}$ & $\begin{array}{c}0.964^{* * *} \\
(0.01)\end{array}$ & $\begin{array}{c}0.964 * * * \\
(0.01)\end{array}$ & $\begin{array}{c}0.964 * * * \\
(0.01)\end{array}$ & $\begin{array}{c}0.964^{* * * *} \\
(0.01)\end{array}$ \\
\hline \multicolumn{9}{|l|}{ Length of Depressive episode } \\
\hline Mental Illness* & $\begin{array}{c}0.776^{* * *} \\
(0.25)\end{array}$ & $\begin{array}{c}0.776^{* * *} \\
(0.25)\end{array}$ & $\begin{array}{c}0.775 * * * \\
(0.25)\end{array}$ & $\begin{array}{c}0.775^{* * * *} \\
(0.25)\end{array}$ & $\begin{array}{c}0.648^{* * *} \\
(0.10)\end{array}$ & $\begin{array}{c}0.649 * * * \\
(0.10)\end{array}$ & $\begin{array}{c}0.650^{* * *} \\
(0.10)\end{array}$ & $\begin{array}{c}0.650^{* * * *} \\
(0.10)\end{array}$ \\
\hline \multicolumn{9}{|l|}{ Sweating } \\
\hline Mental Illness* & $\begin{array}{c}0.131^{* * *} \\
(0.03)\end{array}$ & $\begin{array}{c}0.131^{* * *} \\
(0.03)\end{array}$ & $\begin{array}{c}0.131^{* * *} \\
(0.03)\end{array}$ & $\begin{array}{c}0.131^{* * *} \\
(0.03)\end{array}$ & $\begin{array}{c}0.090^{* * *} \\
(0.02)\end{array}$ & $\begin{array}{c}0.090^{* * *} \\
(0.02)\end{array}$ & $\begin{array}{c}0.090^{* * * *} \\
(0.02)\end{array}$ & $\begin{array}{c}0.090^{* * *} \\
(0.02)\end{array}$ \\
\hline \multicolumn{9}{|l|}{ Trembling } \\
\hline Mental Illness* & $\begin{array}{c}0.111^{* * *} \\
(0.03)\end{array}$ & $\begin{array}{c}0.111^{* * *} \\
(0.03)\end{array}$ & $\begin{array}{c}0.111^{* * *} \\
(0.04)\end{array}$ & $\begin{array}{c}0.111^{* * *} \\
(0.04)\end{array}$ & $\begin{array}{c}0.059^{* * *} \\
(0.02)\end{array}$ & $\begin{array}{c}0.060 * * * \\
(0.02)\end{array}$ & $\begin{array}{c}0.059 * * * \\
(0.02)\end{array}$ & $\begin{array}{c}0.060^{* * *} \\
(0.02)\end{array}$ \\
\hline Choking & & & & & & & & \\
\hline Mental Illness* & $\begin{array}{c}0.221^{* * *} \\
(0.05)\end{array}$ & $\begin{array}{c}0.222^{* * *} \\
(0.05)\end{array}$ & $\begin{array}{c}0.222^{* * *} \\
(0.05)\end{array}$ & $\begin{array}{c}0.223^{* * *} \\
(0.05)\end{array}$ & $\begin{array}{c}0.165^{* * *} \\
(0.02)\end{array}$ & $\begin{array}{c}0.165 * * * \\
(0.02)\end{array}$ & $\begin{array}{c}0.165^{* * *} \\
(0.02)\end{array}$ & $\begin{array}{c}0.165^{* * *} \\
(0.02)\end{array}$ \\
\hline Chest pain or nausea & & & & & & & & \\
\hline Mental Illness* & $\begin{array}{c}0.204^{* * *} \\
(0.05)\end{array}$ & $\begin{array}{c}0.205^{* * *} \\
(0.05)\end{array}$ & $\begin{array}{c}0.205^{* * *} \\
(0.05)\end{array}$ & $\begin{array}{c}0.206^{* * *} \\
(0.05)\end{array}$ & $\begin{array}{c}0.196^{* * *} \\
(0.03)\end{array}$ & $\begin{array}{c}0.196^{* * *} \\
(0.03)\end{array}$ & $\begin{array}{c}0.196^{* * *} \\
(0.03)\end{array}$ & $\begin{array}{c}0.196^{* * *} \\
(0.03)\end{array}$ \\
\hline Dizziness or unreality & & & & & & & & \\
\hline Mental Illness* & $\begin{array}{c}0.203^{* * *} \\
(0.03)\end{array}$ & $\begin{array}{c}0.204^{* * *} \\
(0.03)\end{array}$ & $\begin{array}{c}0.204^{* * *} \\
(0.03)\end{array}$ & $\begin{array}{c}0.204^{* * *} \\
(0.03)\end{array}$ & $\begin{array}{c}0.156^{* * *} \\
(0.03)\end{array}$ & $\begin{array}{c}0.156^{* * *} \\
(0.03)\end{array}$ & $\begin{array}{c}0.156^{* * *} \\
(0.03)\end{array}$ & $\begin{array}{c}0.156^{* * *} \\
(0.03)\end{array}$ \\
\hline Afraid meeting new people & & & & & & & & \\
\hline Mental Illness* & $\begin{array}{c}0.299 * * * \\
(0.06)\end{array}$ & $\begin{array}{c}0.301^{* * *} \\
(0.06)\end{array}$ & $\begin{array}{c}0.300^{* * *} \\
(0.06)\end{array}$ & $\begin{array}{c}0.302 * * * \\
(0.06)\end{array}$ & $\begin{array}{c}0.187^{* * *} \\
(0.03)\end{array}$ & $\begin{array}{c}0.188^{* * *} \\
(0.03)\end{array}$ & $\begin{array}{c}0.188^{* * *} \\
(0.03)\end{array}$ & $\begin{array}{c}0.188^{* * * *} \\
(0.03)\end{array}$ \\
\hline Afraid talking to authority & & & & & & & & \\
\hline Mental Illness* & $\begin{array}{c}0.244 * * * \\
(0.06)\end{array}$ & $\begin{array}{c}0.245^{* * *} \\
(0.06)\end{array}$ & $\begin{array}{c}0.245^{* * *} \\
(0.06)\end{array}$ & $\begin{array}{c}0.246 * * * \\
(0.06)\end{array}$ & $\begin{array}{c}0.144^{* * *} \\
(0.03)\end{array}$ & $\begin{array}{c}0.145 * * * \\
(0.03)\end{array}$ & $\begin{array}{c}0.145 * * * \\
(0.03)\end{array}$ & $\begin{array}{c}0.145^{* * *} \\
(0.03)\end{array}$ \\
\hline Shy at social gathering & & & & & & & & \\
\hline Mental Illness* & $\begin{array}{c}0.253^{* * *} \\
(0.05)\end{array}$ & $\begin{array}{c}0.254^{* * *} \\
(0.05)\end{array}$ & $\begin{array}{c}0.254^{* * *} \\
(0.05)\end{array}$ & $\begin{array}{c}0.255^{* * *} \\
(0.05)\end{array}$ & $\begin{array}{c}0.170^{* * *} \\
(0.02)\end{array}$ & $\begin{array}{c}0.170 * * * \\
(0.02)\end{array}$ & $\begin{array}{c}0.170^{* * *} \\
(0.02)\end{array}$ & $\begin{array}{c}0.171^{* * *} \\
(0.02)\end{array}$ \\
\hline Shy performing & & & & & & & & \\
\hline Mental Illness* & $\begin{array}{c}0.253^{* * *} \\
(0.06)\end{array}$ & $\begin{array}{c}0.255^{* * *} \\
(0.06)\end{array}$ & $\begin{array}{c}0.254^{* * *} \\
(0.06)\end{array}$ & $\begin{array}{c}0.256^{* * *} \\
(0.06)\end{array}$ & $\begin{array}{c}0.184^{* * *} \\
(0.03)\end{array}$ & $\begin{array}{c}0.185 * * * \\
(0.03)\end{array}$ & $\begin{array}{c}0.185 * * * \\
(0.03)\end{array}$ & $\begin{array}{c}0.185^{* * *} \\
(0.03)\end{array}$ \\
\hline Shy of unknown people & & & & & & & & \\
\hline Mental Illness* & $\begin{array}{c}0.229^{* * *} \\
(0.06)\end{array}$ & $\begin{array}{c}0.230^{* * *} \\
(0.06)\end{array}$ & $\begin{array}{c}0.230^{* * *} \\
(0.06)\end{array}$ & $\begin{array}{c}0.231^{* * *} \\
(0.06)\end{array}$ & $\begin{array}{c}0.140^{* * *} \\
(0.02)\end{array}$ & $\begin{array}{c}0.141^{* * *} \\
(0.02)\end{array}$ & $\begin{array}{c}0.141^{* * *} \\
(0.02)\end{array}$ & $\begin{array}{c}0.141^{* * *} \\
(0.02)\end{array}$ \\
\hline Shy at disagreement & & & & & & & & \\
\hline Mental Illness* & $\begin{array}{c}0.235^{* * *} \\
(0.05)\end{array}$ & $\begin{array}{c}0.236^{* * *} \\
(0.05)\end{array}$ & $\begin{array}{c}0.236^{* * *} \\
(0.05)\end{array}$ & $\begin{array}{c}0.237^{* * *} \\
(0.05)\end{array}$ & $\begin{array}{c}0.130^{* * *} \\
(0.03)\end{array}$ & $\begin{array}{c}0.131^{* * *} \\
(0.03)\end{array}$ & $\begin{array}{c}0.131^{* * *} \\
(0.03)\end{array}$ & $\begin{array}{c}0.131^{* * *} \\
(0.03)\end{array}$ \\
\hline Shy with others watching & & & & & & & & \\
\hline Mental Illness* & $\begin{array}{c}0.174^{* * *} \\
(0.05)\end{array}$ & $\begin{array}{c}0.174^{* * * *} \\
(0.05)\end{array}$ & $\begin{array}{c}0.174 * * * \\
(0.05)\end{array}$ & $\begin{array}{c}0.175^{* * *} \\
(0.05)\end{array}$ & $\begin{array}{c}0.112^{* * *} \\
(0.03)\end{array}$ & $\begin{array}{c}0.113^{* * *} \\
(0.03)\end{array}$ & $\begin{array}{c}0.113^{* * *} \\
(0.03)\end{array}$ & $\begin{array}{c}0.113^{* * *} \\
(0.03)\end{array}$ \\
\hline Shy using public restroom & & & & & & & & \\
\hline Mental IIIness* & $\begin{array}{c}0.150^{* * *} \\
(0.04)\end{array}$ & $\begin{array}{c}0.151^{* * *} \\
(0.04)\end{array}$ & $\begin{array}{c}0.151^{* * *} \\
(0.04)\end{array}$ & $\begin{array}{c}0.152^{* * *} \\
(0.04)\end{array}$ & $\begin{array}{c}0.102^{* * *} \\
(0.02)\end{array}$ & $\begin{array}{c}0.102^{* * *} \\
(0.02)\end{array}$ & $\begin{array}{c}0.102^{* * *} \\
(0.02)\end{array}$ & $\begin{array}{c}0.102^{* * *} \\
(0.02)\end{array}$ \\
\hline Shy in dating situation & & & & & & & & \\
\hline Mental IIIness* & $\begin{array}{c}0.199^{* * *} \\
(0.05)\end{array}$ & $\begin{array}{c}0.201^{* * *} \\
(0.05)\end{array}$ & $\begin{array}{c}0.200^{* * *} \\
(0.05)\end{array}$ & $\begin{array}{c}0.201 * * * \\
(0.05)\end{array}$ & $\begin{array}{c}0.150^{* * *} \\
(0.03)\end{array}$ & $\begin{array}{c}0.150^{* * * *} \\
(0.03)\end{array}$ & $\begin{array}{c}0.150^{* * *} \\
(0.03)\end{array}$ & $\begin{array}{c}0.151^{* * *} \\
(0.03)\end{array}$ \\
\hline Uncomfortable getting atter & & & & & & & & \\
\hline Mental Illness* & $\begin{array}{c}0.270^{* * *} \\
(0.06)\end{array}$ & $\begin{array}{c}0.271^{* * *} \\
(0.06)\end{array}$ & $\begin{array}{c}0.271^{* * *} \\
(0.06)\end{array}$ & $\begin{array}{c}0.272^{* * *} \\
(0.06)\end{array}$ & $\begin{array}{c}0.172^{* * *} \\
(0.03)\end{array}$ & $\begin{array}{c}0.173^{* * *} \\
(0.03)\end{array}$ & $\begin{array}{c}0.173^{* * *} \\
(0.03)\end{array}$ & $\begin{array}{c}0.173^{* * *} \\
(0.03)\end{array}$ \\
\hline Fear of embarrassment & & & & & & & & \\
\hline Mental Illness* & $\begin{array}{c}0.305^{* * *} \\
(0.07)\end{array}$ & $\begin{array}{c}0.308^{* * *} \\
(0.07)\end{array}$ & $\begin{array}{c}0.307^{* * *} \\
(0.07)\end{array}$ & $\begin{array}{c}0.309^{* * *} \\
(0.07)\end{array}$ & $\begin{array}{c}0.199^{* * *} \\
(0.03)\end{array}$ & $\begin{array}{c}0.200^{* * *} \\
(0.03)\end{array}$ & $\begin{array}{c}0.200^{* * *} \\
(0.03)\end{array}$ & $\begin{array}{c}0.201^{* * *} \\
(0.03)\end{array}$ \\
\hline Fear of social situation & & & & & & & & \\
\hline Mental Illness* & $\begin{array}{c}0.270^{* * *} \\
(0.06)\end{array}$ & $\begin{array}{c}0.272^{* * *} \\
(0.07)\end{array}$ & $\begin{array}{c}0.272^{* * *} \\
(0.07)\end{array}$ & $\begin{array}{c}0.274^{* * *} \\
(0.07)\end{array}$ & $\begin{array}{c}0.182^{* * *} \\
(0.03)\end{array}$ & $\begin{array}{c}0.183^{* * *} \\
(0.03)\end{array}$ & $\begin{array}{c}0.183^{* * *} \\
(0.03)\end{array}$ & $\begin{array}{c}0.183^{* * *} \\
(0.03)\end{array}$ \\
\hline Avoid social situations & & & & & & & & \\
\hline Mental Illness* & $\begin{array}{c}0.328^{* * *} \\
(0.06)\end{array}$ & $\begin{array}{c}0.330^{* * *} \\
(0.07)\end{array}$ & $\begin{array}{c}0.329^{* * *} \\
(0.07)\end{array}$ & $\begin{array}{c}0.331^{* * *} \\
(0.07)\end{array}$ & $\begin{array}{c}0.196^{* * *} \\
(0.03)\end{array}$ & $\begin{array}{c}0.197 * * * \\
(0.03)\end{array}$ & $\begin{array}{c}0.197^{* * *} \\
(0.03)\end{array}$ & $\begin{array}{c}0.197 * * * \\
(0.03)\end{array}$ \\
\hline Social situations cause inten & & & & & & & & \\
\hline Mental Illness* & $\begin{array}{c}0.279^{* * *} \\
(0.06)\end{array}$ & $\begin{array}{c}0.282^{* * *} \\
(0.06)\end{array}$ & $\begin{array}{c}0.281^{* * *} \\
(0.06)\end{array}$ & $\begin{array}{c}0.283^{* * *} \\
(0.07)\end{array}$ & $\begin{array}{c}0.192^{* * *} \\
(0.03)\end{array}$ & $\begin{array}{c}0.193 * * * \\
(0.03)\end{array}$ & $\begin{array}{c}0.193^{* * *} \\
(0.03)\end{array}$ & $\begin{array}{c}0.193^{* * *} \\
(0.03)\end{array}$ \\
\hline Recent occurrence after age & & & & & & & & \\
\hline Mental IIIness* & $\begin{array}{c}0.330^{* * * *} \\
(0.07)\end{array}$ & $\begin{array}{c}0.332^{* * * *} \\
(0.07)\end{array}$ & $\begin{array}{c}0.331^{* * * *} \\
(0.07)\end{array}$ & $\begin{array}{c}0.333^{* * *} \\
(0.07)\end{array}$ & $\begin{array}{c}0.196^{* * *} \\
(0.03)\end{array}$ & $\begin{array}{c}0.197 * * * \\
(0.03)\end{array}$ & $\begin{array}{c}0.197^{* * *} \\
(0.03)\end{array}$ & $\begin{array}{c}0.197^{* * *} \\
(0.03)\end{array}$ \\
\hline Excess anxiety & & & & & & & & \\
\hline Mental Illness* & $\begin{array}{c}0.396^{* * *} \\
(0.06)\end{array}$ & $\begin{array}{c}0.397^{* * *} \\
(0.06)\end{array}$ & $\begin{array}{c}0.398^{* * *} \\
(0.06)\end{array}$ & $\begin{array}{c}0.398^{* * *} \\
(0.06)\end{array}$ & $\begin{array}{c}0.344^{* * *} \\
(0.04)\end{array}$ & $\begin{array}{c}0.344^{* * *} \\
(0.04)\end{array}$ & $\begin{array}{c}0.344^{* * *} \\
(0.04)\end{array}$ & $\begin{array}{c}0.345^{* * *} \\
(0.04)\end{array}$ \\
\hline Length of GAD episode & & & & & & & & \\
\hline Mental IIIness* & $\begin{array}{c}0.543^{* *} \\
(0.23)\end{array}$ & $\begin{array}{c}0.544^{* *} \\
(0.23)\end{array}$ & $\begin{array}{c}0.542^{* *} \\
(0.23)\end{array}$ & $\begin{array}{c}0.543^{* *} \\
(0.23)\end{array}$ & $\begin{array}{c}0.380^{* * *} \\
(0.12)\end{array}$ & $\begin{array}{c}0.381^{* * *} \\
(0.12)\end{array}$ & $\begin{array}{c}0.381^{* * *} \\
(0.12)\end{array}$ & $\begin{array}{c}0.381^{* * *} \\
(0.12)\end{array}$ \\
\hline Difficult to control worry & & & & & & & & \\
\hline Mental Illness* & $\begin{array}{c}0.384^{* * *} \\
(0.06)\end{array}$ & $\begin{array}{c}0.385^{* * *} \\
(0.06)\end{array}$ & $\begin{array}{c}0.385 * * * \\
(0.06)\end{array}$ & $\begin{array}{c}0.386^{* * *} \\
(0.06)\end{array}$ & $\begin{array}{c}0.328^{* * *} \\
(0.04)\end{array}$ & $\begin{array}{c}0.328^{* * *} \\
(0.04)\end{array}$ & $\begin{array}{c}0.328^{* * *} \\
(0.04)\end{array}$ & $\begin{array}{c}0.328^{* * *} \\
(0.04)\end{array}$ \\
\hline Restlessness & & & & & & & & \\
\hline Mental Illness* & $\begin{array}{c}0.366^{* * *} \\
(0.06)\end{array}$ & $\begin{array}{c}0.368^{* * *} \\
(0.06)\end{array}$ & $\begin{array}{c}0.368^{* * *} \\
(0.06)\end{array}$ & $\begin{array}{c}0.369^{* * *} \\
(0.06)\end{array}$ & $\begin{array}{c}0.306^{* * *} \\
(0.04)\end{array}$ & $\begin{array}{c}0.307^{* * *} \\
(0.04)\end{array}$ & $\begin{array}{c}0.307^{* * *} \\
(0.04)\end{array}$ & $\begin{array}{c}0.307^{* * *} \\
(0.04)\end{array}$ \\
\hline Tired & & & & & & & & \\
\hline Mental Illness* & $\begin{array}{c}0.294^{* * *} \\
(0.06)\end{array}$ & $\begin{array}{c}0.296^{* * *} \\
(0.06)\end{array}$ & $\begin{array}{c}0.296^{* * *} \\
(0.06)\end{array}$ & $\begin{array}{c}0.297 * * * \\
(0.06)\end{array}$ & $\begin{array}{c}0.310^{* * *} \\
(0.03)\end{array}$ & $\begin{array}{c}0.311^{* * *} \\
(0.04)\end{array}$ & $\begin{array}{c}0.311^{* * *} \\
(0.03)\end{array}$ & $\begin{array}{c}0.311^{* * *} \\
(0.03)\end{array}$ \\
\hline Irritable & & & & & & & & \\
\hline Mental Illness* & $\begin{array}{c}0.336^{* * *} \\
(0.06)\end{array}$ & $\begin{array}{c}0.338^{* * *} \\
(0.06)\end{array}$ & $\begin{array}{c}0.338^{* * *} \\
(0.06)\end{array}$ & $\begin{array}{c}0.339^{* * *} \\
(0.06)\end{array}$ & $\begin{array}{c}0.303^{* * *} \\
(0.04)\end{array}$ & $\begin{array}{c}0.303^{* * *} \\
(0.04)\end{array}$ & $\begin{array}{c}0.303^{* * *} \\
(0.04)\end{array}$ & $\begin{array}{c}0.304^{* * *} \\
(0.04)\end{array}$ \\
\hline Difficulty concentrating & & & & & & & & \\
\hline Mental Illness* & $\begin{array}{c}0.367^{* * *} \\
(0.06)\end{array}$ & $\begin{array}{c}0.368^{* * *} \\
(0.06)\end{array}$ & $\begin{array}{c}0.368^{* * *} \\
(0.06)\end{array}$ & $\begin{array}{c}0.369^{* * *} \\
(0.06)\end{array}$ & $\begin{array}{c}0.302^{* * *} \\
(0.04)\end{array}$ & $\begin{array}{c}0.303^{* * *} \\
(0.04)\end{array}$ & $\begin{array}{c}0.303^{* * *} \\
(0.04)\end{array}$ & $\begin{array}{c}0.303^{* * *} \\
(0.04)\end{array}$ \\
\hline Tense muscles & & & & & & & & \\
\hline Mental IIIness* & $\begin{array}{c}0.206^{* * *} \\
(0.04)\end{array}$ & $\begin{array}{c}0.207^{* * *} \\
(0.04)\end{array}$ & $\begin{array}{c}0.207 * * * \\
(0.04)\end{array}$ & $\begin{array}{c}0.208^{* * *} \\
(0.04)\end{array}$ & $\begin{array}{c}0.266^{* * *} \\
(0.03)\end{array}$ & $\begin{array}{c}0.266^{* * *} \\
(0.03)\end{array}$ & $\begin{array}{c}0.266^{* * *} \\
(0.03)\end{array}$ & $\begin{array}{c}0.266^{* * *} \\
(0.03)\end{array}$ \\
\hline Sleeping problems & & & & & & & & \\
\hline Mental IIIness* & $\begin{array}{c}0.332^{* * *} \\
(0.05)\end{array}$ & $\begin{array}{c}0.334^{* * *} \\
(0.05)\end{array}$ & $\begin{array}{c}0.334^{* * *} \\
(0.05)\end{array}$ & $\begin{array}{c}0.334^{* * *} \\
(0.06)\end{array}$ & $\begin{array}{c}0.301^{* * *} \\
(0.04)\end{array}$ & $\begin{array}{c}0.301 * * * \\
(0.04)\end{array}$ & $\begin{array}{c}0.302^{* * *} \\
(0.04)\end{array}$ & $\begin{array}{c}0.302^{* * *} \\
(0.04)\end{array}$ \\
\hline
\end{tabular}




\begin{tabular}{|c|c|c|c|c|c|c|c|c|}
\hline Mental Illness* & $\begin{array}{c}0.319^{* * *} \\
(0.06)\end{array}$ & $\begin{array}{c}0.320^{* * *} \\
(0.06)\end{array}$ & $\begin{array}{c}0.320^{* * *} \\
(0.06)\end{array}$ & $\begin{array}{c}0.321^{* * *} \\
(0.06)\end{array}$ & $\begin{array}{c}0.294^{* * *} \\
(0.04)\end{array}$ & $\begin{array}{c}0.294^{* * *} \\
(0.04)\end{array}$ & $\begin{array}{c}0.294^{* * *} \\
(0.04)\end{array}$ & $\begin{array}{c}0.295^{* * *} \\
(0.04)\end{array}$ \\
\hline \multicolumn{9}{|l|}{ Significant emotional distress } \\
\hline Mental Illness* & $\begin{array}{c}0.378^{* * *} \\
(0.06)\end{array}$ & $\begin{array}{c}0.380^{* * *} \\
(0.06)\end{array}$ & $\begin{array}{c}0.380^{* * *} \\
(0.06)\end{array}$ & $\begin{array}{c}0.381^{* * *} \\
(0.06)\end{array}$ & $\begin{array}{c}0.333^{* * *} \\
(0.04)\end{array}$ & $\begin{array}{c}0.333^{* * *} \\
(0.04)\end{array}$ & $\begin{array}{c}0.334^{* * *} \\
(0.04)\end{array}$ & $\begin{array}{c}0.334^{* * *} \\
(0.04)\end{array}$ \\
\hline \multicolumn{9}{|c|}{ Worry not always due to physical causes } \\
\hline Mental Illness* & $\begin{array}{c}0.161^{* * *} \\
(0.04)\end{array}$ & $\begin{array}{c}0.161^{* * *} \\
(0.04)\end{array}$ & $\begin{array}{c}0.161^{* * *} \\
(0.04)\end{array}$ & $\begin{array}{c}0.162^{* * *} \\
(0.04)\end{array}$ & $\begin{array}{c}0.054^{* * *} \\
(0.02)\end{array}$ & $\begin{array}{c}0.054^{* * *} \\
(0.02)\end{array}$ & $\begin{array}{c}0.054^{* * *} \\
(0.02)\end{array}$ & $\begin{array}{c}0.054^{* * *} \\
(0.02)\end{array}$ \\
\hline N & 2710 & 2710 & 2710 & 2710 & 2815 & 2815 & 2815 & 2815 \\
\hline
\end{tabular}


Table 11 : Model II : Effect of mental illness on number of days missed in past month conditional on being employed

\begin{tabular}{|c|c|c|c|c|c|c|c|c|}
\hline & \multicolumn{4}{|c|}{ Male } & \multicolumn{4}{|c|}{ Female } \\
\hline & $\begin{array}{c}(1) \\
\text { No instruments }\end{array}$ & $\begin{array}{l}\text { (2) } \\
\text { IV }\end{array}$ & $\begin{array}{c}\text { (3) } \\
\text { Lewbel IV, no external } \\
\text { instrument }\end{array}$ & $\begin{array}{c}\text { (4) } \\
\text { Lewbel IV with external } \\
\text { instrument }\end{array}$ & $\begin{array}{c}\text { (5) } \\
\text { No instruments }\end{array}$ & $\begin{array}{l}6) \\
\text { IV }\end{array}$ & $\begin{array}{c}(7) \\
\text { Lewbel IV, no external } \\
\text { instrument }\end{array}$ & $\begin{array}{c}(8) \\
\text { Lewbel IV with external } \\
\text { instrument }\end{array}$ \\
\hline \multicolumn{9}{|l|}{ Labor market equation } \\
\hline \multicolumn{9}{|l|}{ Days missed in past month conditional on employment } \\
\hline Mental Illness* & $\begin{array}{c}1.431^{* * *} \\
(0.53)\end{array}$ & $\begin{array}{l}1.363 \\
(1.70)\end{array}$ & $\begin{array}{c}3.238^{* * *} \\
(1.19)\end{array}$ & $\begin{array}{c}3.012^{* * *} \\
(1.15)\end{array}$ & $\begin{array}{l}0.313 \\
(0.26)\end{array}$ & $\begin{array}{l}1.259 \\
(0.94)\end{array}$ & $\begin{array}{l}0.769 \\
(0.57)\end{array}$ & $\begin{array}{l}0.785 \\
(0.58)\end{array}$ \\
\hline Age & $\begin{array}{l}-0.092 \\
(0.09)\end{array}$ & $\begin{array}{l}-0.092 \\
(0.09)\end{array}$ & $\begin{array}{l}-0.098 \\
(0.09)\end{array}$ & $\begin{array}{l}-0.097 \\
(0.09)\end{array}$ & $\begin{array}{l}0.010 \\
(0.08)\end{array}$ & $\begin{array}{l}0.005 \\
(0.09)\end{array}$ & $\begin{array}{l}0.008 \\
(0.08)\end{array}$ & $\begin{array}{l}0.008 \\
(0.08)\end{array}$ \\
\hline Age squared & $\begin{array}{l}0.001 \\
(0.00)\end{array}$ & $\begin{array}{l}0.001 \\
(0.00)\end{array}$ & $\begin{array}{l}0.001 \\
(0.00)\end{array}$ & $\begin{array}{l}0.001 \\
(0.00)\end{array}$ & $\begin{array}{l}-0.000 \\
(0.00)\end{array}$ & $\begin{array}{l}-0.000 \\
(0.00)\end{array}$ & $\begin{array}{l}-0.000 \\
(0.00)\end{array}$ & $\begin{array}{l}-0.000 \\
(0.00)\end{array}$ \\
\hline Asian & $\begin{array}{l}-0.183 \\
(0.27)\end{array}$ & $\begin{array}{l}-0.186 \\
(0.30)\end{array}$ & $\begin{array}{l}-0.122 \\
(0.28)\end{array}$ & $\begin{array}{l}-0.130 \\
(0.28)\end{array}$ & $\begin{array}{c}1.077^{* * *} \\
(0.29)\end{array}$ & $\begin{array}{c}1.147^{* * *} \\
(0.31)\end{array}$ & $\begin{array}{c}1.111^{* * *} \\
(0.30)\end{array}$ & $\begin{array}{c}1.112^{* * *} \\
(0.30)\end{array}$ \\
\hline Latino & $\begin{array}{l}-0.187 \\
(0.34)\end{array}$ & $\begin{array}{l}-0.189 \\
(0.39)\end{array}$ & $\begin{array}{l}-0.118 \\
(0.34)\end{array}$ & $\begin{array}{l}-0.127 \\
(0.35)\end{array}$ & $\begin{array}{l}0.252 \\
(0.28)\end{array}$ & $\begin{array}{l}0.305 \\
(0.30)\end{array}$ & $\begin{array}{l}0.278 \\
(0.29)\end{array}$ & $\begin{array}{l}0.279 \\
(0.29)\end{array}$ \\
\hline Africanamerican & $\begin{array}{l}-0.169 \\
(0.35)\end{array}$ & $\begin{array}{l}-0.172 \\
(0.38)\end{array}$ & $\begin{array}{l}-0.085 \\
(0.35)\end{array}$ & $\begin{array}{l}-0.095 \\
(0.36)\end{array}$ & $\begin{array}{l}0.495 \\
(0.50)\end{array}$ & $\begin{array}{l}0.572 \\
(0.50)\end{array}$ & $\begin{array}{l}0.532 \\
(0.50)\end{array}$ & $\begin{array}{l}0.534 \\
(0.50)\end{array}$ \\
\hline Married & $\begin{array}{l}0.216 \\
(0.18)\end{array}$ & $\begin{array}{l}0.212 \\
(0.18)\end{array}$ & $\begin{array}{c}0.318^{*} \\
(0.18)\end{array}$ & $\begin{array}{c}0.305^{*} \\
(0.18)\end{array}$ & $\begin{array}{l}-0.513 \\
(0.51)\end{array}$ & $\begin{array}{l}-0.439 \\
(0.55)\end{array}$ & $\begin{array}{l}-0.478 \\
(0.52)\end{array}$ & $\begin{array}{l}-0.476 \\
(0.53)\end{array}$ \\
\hline Divorced & $\begin{array}{l}0.835 \\
(0.78)\end{array}$ & $\begin{array}{l}0.835 \\
(0.77)\end{array}$ & $\begin{array}{l}0.844 \\
(0.77)\end{array}$ & $\begin{array}{l}0.843 \\
(0.77)\end{array}$ & $\begin{array}{l}-0.387 \\
(0.54)\end{array}$ & $\begin{array}{l}-0.386 \\
(0.55)\end{array}$ & $\begin{array}{l}-0.386 \\
(0.54)\end{array}$ & $\begin{array}{l}-0.386 \\
(0.54)\end{array}$ \\
\hline 12 years of education & $\begin{array}{l}-0.529 \\
(0.55)\end{array}$ & $\begin{array}{l}-0.530 \\
(0.55)\end{array}$ & $\begin{array}{l}-0.509 \\
(0.55)\end{array}$ & $\begin{array}{l}-0.511 \\
(0.55)\end{array}$ & $\begin{array}{l}-0.746 \\
(0.62)\end{array}$ & $\begin{array}{l}-0.747 \\
(0.62)\end{array}$ & $\begin{array}{l}-0.747 \\
(0.62)\end{array}$ & $\begin{array}{l}-0.747 \\
(0.62)\end{array}$ \\
\hline $13-15$ years of education & $\begin{array}{c}-1.062^{*} \\
(0.55)\end{array}$ & $\begin{array}{c}-1.063^{*} \\
(0.56)\end{array}$ & $\begin{array}{c}-1.041^{*} \\
(0.55)\end{array}$ & $\begin{array}{c}-1.044^{*} \\
(0.55)\end{array}$ & $\begin{array}{c}-1.144^{*} \\
(0.63)\end{array}$ & $\begin{array}{c}-1.134^{*} \\
(0.63)\end{array}$ & $\begin{array}{c}-1.139 * \\
(0.63)\end{array}$ & $\begin{array}{c}-1.139 * \\
(0.63)\end{array}$ \\
\hline 16 or more years of education & $\begin{array}{c}-0.964^{*} \\
(0.51)\end{array}$ & $\begin{array}{c}-0.965^{*} \\
(0.53)\end{array}$ & $\begin{array}{c}-0.917^{*} \\
(0.52)\end{array}$ & $\begin{array}{c}-0.922^{*} \\
(0.52)\end{array}$ & $\begin{array}{l}-1.007 \\
(0.67)\end{array}$ & $\begin{array}{l}-0.994 \\
(0.67)\end{array}$ & $\begin{array}{r}-1.001 \\
(0.67)\end{array}$ & $\begin{array}{l}-1.000 \\
(0.67)\end{array}$ \\
\hline Chronic conditions & $\begin{array}{l}0.271 \\
(0.27)\end{array}$ & $\begin{array}{l}0.273 \\
(0.25)\end{array}$ & $\begin{array}{l}0.223 \\
(0.27)\end{array}$ & $\begin{array}{l}0.229 \\
(0.26)\end{array}$ & $\begin{array}{l}0.307 \\
(0.23)\end{array}$ & $\begin{array}{l}0.257 \\
(0.24)\end{array}$ & $\begin{array}{l}0.283 \\
(0.24)\end{array}$ & $\begin{array}{l}0.282 \\
(0.24)\end{array}$ \\
\hline Midwest & $\begin{array}{l}0.176 \\
(0.29)\end{array}$ & $\begin{array}{l}0.177 \\
(0.29)\end{array}$ & $\begin{array}{l}0.153 \\
(0.28)\end{array}$ & $\begin{array}{l}0.156 \\
(0.28)\end{array}$ & $\begin{array}{l}-0.377 \\
(0.37)\end{array}$ & $\begin{array}{l}-0.359 \\
(0.37)\end{array}$ & $\begin{array}{l}-0.368 \\
(0.37)\end{array}$ & $\begin{array}{l}-0.368 \\
(0.37)\end{array}$ \\
\hline South & $\begin{array}{l}0.290 \\
(0.24)\end{array}$ & $\begin{array}{l}0.289 \\
(0.24)\end{array}$ & $\begin{array}{l}0.304 \\
(0.23)\end{array}$ & $\begin{array}{l}0.302 \\
(0.23)\end{array}$ & $\begin{array}{l}-0.322 \\
(0.39)\end{array}$ & $\begin{array}{l}-0.306 \\
(0.39)\end{array}$ & $\begin{array}{l}-0.314 \\
(0.39)\end{array}$ & $\begin{array}{l}-0.314 \\
(0.39)\end{array}$ \\
\hline West & $\begin{array}{l}0.511 \\
(0.39)\end{array}$ & $\begin{array}{l}0.512 \\
(0.40)\end{array}$ & $\begin{array}{l}0.486 \\
(0.39)\end{array}$ & $\begin{array}{l}0.489 \\
(0.39)\end{array}$ & $\begin{array}{r}-0.233 \\
(0.38)\end{array}$ & $\begin{array}{r}-0.236 \\
(0.37)\end{array}$ & $\begin{array}{l}-0.234 \\
(0.37)\end{array}$ & $\begin{array}{r}-0.234 \\
(0.37)\end{array}$ \\
\hline Mental IIIness equation & & & & & & & & \\
\hline Mental IIIness* & & & & & & & & \\
\hline Age & $\begin{array}{l}0.003 \\
(0.01)\end{array}$ & $\begin{array}{l}0.003 \\
(0.01)\end{array}$ & $\begin{array}{l}0.001 \\
(0.01)\end{array}$ & $\begin{array}{l}0.001 \\
(0.01)\end{array}$ & $\begin{array}{l}0.005 \\
(0.00)\end{array}$ & $\begin{array}{l}0.003 \\
(0.00)\end{array}$ & $\begin{array}{l}0.003 \\
(0.00)\end{array}$ & $\begin{array}{l}0.002 \\
(0.00)\end{array}$ \\
\hline Age squared & $\begin{array}{l}-0.000 \\
(0.00)\end{array}$ & $\begin{array}{l}-0.000 \\
(0.00)\end{array}$ & $\begin{array}{l}-0.000 \\
(0.00)\end{array}$ & $\begin{array}{l}-0.000 \\
(0.00)\end{array}$ & $\begin{array}{c}-0.000^{* *} \\
(0.00)\end{array}$ & $\begin{array}{r}-0.000 \\
(0.00)\end{array}$ & $\begin{array}{l}-0.000 \\
(0.00)\end{array}$ & $\begin{array}{l}-0.000 \\
(0.00)\end{array}$ \\
\hline Asian & $\begin{array}{c}-0.034^{* *} \\
(0.01)\end{array}$ & $\begin{array}{l}-0.015 \\
(0.01)\end{array}$ & $\begin{array}{c}-0.029 * * * \\
(0.01)\end{array}$ & $\begin{array}{c}-0.018^{*} \\
(0.01)\end{array}$ & $\begin{array}{c}-0.074^{* * *} \\
(0.02)\end{array}$ & $\begin{array}{c}-0.037^{* *} \\
(0.02)\end{array}$ & $\begin{array}{c}-0.066^{* * *} \\
(0.01)\end{array}$ & $\begin{array}{c}-0.052^{* * * *} \\
(0.01)\end{array}$ \\
\hline Latino & $\begin{array}{c}-0.038^{* * *} \\
(0.01)\end{array}$ & $\begin{array}{c}-0.020^{*} \\
(0.01)\end{array}$ & $\begin{array}{c}-0.023^{*} \\
(0.01)\end{array}$ & $\begin{array}{l}-0.013 \\
(0.01)\end{array}$ & $\begin{array}{c}-0.056^{* * *} \\
(0.02)\end{array}$ & $\begin{array}{l}-0.023 \\
(0.02)\end{array}$ & $\begin{array}{c}-0.034^{* *} \\
(0.01)\end{array}$ & $\begin{array}{r}-0.023 \\
(0.01)\end{array}$ \\
\hline Africanamerican & $\begin{array}{c}-0.047^{* * *} \\
(0.01)\end{array}$ & $\begin{array}{c}-0.037^{* * *} \\
(0.01)\end{array}$ & $\begin{array}{c}-0.036^{* * *} \\
(0.01)\end{array}$ & $\begin{array}{c}-0.031^{* * *} \\
(0.01)\end{array}$ & $\begin{array}{c}-0.081^{* * *} \\
(0.02)\end{array}$ & $\begin{array}{c}-0.055^{* *} \\
(0.02)\end{array}$ & $\begin{array}{c}-0.055^{* * *} \\
(0.02)\end{array}$ & $\begin{array}{c}-0.046^{* *} \\
(0.02)\end{array}$ \\
\hline Married & $\begin{array}{c}-0.056^{* *} \\
(0.03)\end{array}$ & $\begin{array}{c}-0.050^{* *} \\
(0.02)\end{array}$ & $\begin{array}{c}-0.066^{* * *} \\
(0.02)\end{array}$ & $\begin{array}{c}-0.062^{* * *} \\
(0.02)\end{array}$ & $\begin{array}{c}-0.079 * * * \\
(0.02)\end{array}$ & $\begin{array}{c}-0.068^{* * *} \\
(0.03)\end{array}$ & $\begin{array}{c}-0.051^{* * *} \\
(0.01)\end{array}$ & $\begin{array}{c}-0.049 * * * \\
(0.01)\end{array}$ \\
\hline Divorced & -0.005 & -0.004 & 0.010 & 0.010 & $\begin{array}{l}(0.02) \\
-0.001\end{array}$ & 0.000 & 0.024 & $\begin{array}{l}(0.01) \\
0.023\end{array}$ \\
\hline & $(0.03)$ & $(0.03)$ & $(0.02)$ & $(0.02)$ & $(0.03)$ & $(0.03)$ & $(0.02)$ & $(0.02)$ \\
\hline 12 years of education & $\begin{array}{l}-0.011 \\
(0.02)\end{array}$ & $\begin{array}{l}-0.004 \\
(0.02)\end{array}$ & $\begin{array}{l}-0.004 \\
(0.02)\end{array}$ & $\begin{array}{r}-0.000 \\
(0.02)\end{array}$ & $\begin{array}{l}0.001 \\
(0.03)\end{array}$ & $\begin{array}{l}0.017 \\
(0.02)\end{array}$ & $\begin{array}{l}0.013 \\
(0.02)\end{array}$ & $\begin{array}{l}0.017 \\
(0.02)\end{array}$ \\
\hline $13-15$ years of education & $\begin{array}{l}-0.012 \\
(0.02)\end{array}$ & $\begin{array}{l}-0.004 \\
(0.02)\end{array}$ & $\begin{array}{l}-0.002 \\
(0.02)\end{array}$ & $\begin{array}{l}0.001 \\
(0.02)\end{array}$ & $\begin{array}{l}-0.010 \\
(0.03)\end{array}$ & $\begin{array}{l}0.003 \\
(0.02)\end{array}$ & $\begin{array}{l}-0.011 \\
(0.02)\end{array}$ & $\begin{array}{l}-0.006 \\
(0.02)\end{array}$ \\
\hline 16 or more years of education & $\begin{array}{c}(0.02) \\
-0.026 \\
(0.02)\end{array}$ & $\begin{array}{c}-0.02) \\
-0.016 \\
(0.02)\end{array}$ & $\begin{array}{c}(0.011 \\
-0.011 \\
(0.02)\end{array}$ & $\begin{array}{c}(0.02) \\
-0.006 \\
(0.02)\end{array}$ & $\begin{array}{c}(0.03) \\
-0.013 \\
(0.03)\end{array}$ & $\begin{array}{r}(0.0) \\
-0.000 \\
(0.02)\end{array}$ & $\begin{array}{l}(0.02) \\
0.005 \\
(0.02)\end{array}$ & $\begin{array}{l}(0.02) \\
0.007 \\
(0.02)\end{array}$ \\
\hline Chronic conditions & $\begin{array}{c}0.026^{* *} \\
(0.01)\end{array}$ & $\begin{array}{l}0.013 \\
(0.01)\end{array}$ & $\begin{array}{c}0.027^{* *} \\
(0.01)\end{array}$ & $\begin{array}{l}0.018^{*} \\
(0.01)\end{array}$ & $\begin{array}{c}0.053^{* * *} \\
(0.01)\end{array}$ & $\begin{array}{c}0.031^{* *} \\
(0.01)\end{array}$ & $\begin{array}{c}0.040^{* * *} \\
(0.01)\end{array}$ & $\begin{array}{c}0.034^{* * *} \\
(0.01)\end{array}$ \\
\hline Midwest & $\begin{array}{l}0.013 \\
(0.02)\end{array}$ & $\begin{array}{l}0.016 \\
(0.02)\end{array}$ & $\begin{array}{l}0.015 \\
(0.01)\end{array}$ & $\begin{array}{l}0.017 \\
(0.01)\end{array}$ & $\begin{array}{l}-0.019 \\
(0.03)\end{array}$ & $\begin{array}{l}-0.016 \\
(0.02)\end{array}$ & $\begin{array}{l}-0.006 \\
(0.02)\end{array}$ & $\begin{array}{l}-0.006 \\
(0.02)\end{array}$ \\
\hline South & -0.008 & 0.007 & 0.002 & 0.011 & -0.016 & -0.005 & -0.010 & -0.006 \\
\hline & $(0.02)$ & $(0.02)$ & $(0.01)$ & $(0.01)$ & $(0.03)$ & $(0.02)$ & $(0.02)$ & $(0.02)$ \\
\hline West & 0.014 & 0.015 & 0.006 & 0.007 & 0.004 & 0.003 & 0.006 & 0.005 \\
\hline & $(0.02)$ & $(0.02)$ & $(0.01)$ & $(0.01)$ & $(0.02)$ & $(0.02)$ & $(0.02)$ & $(0.02)$ \\
\hline \# early onset of psychiatric disorders & & $\begin{array}{c}0.050^{* * *} \\
(0.01)\end{array}$ & & $\begin{array}{c}0.030^{* * *} \\
(0.00)\end{array}$ & & $\begin{array}{c}0.076^{* * *} \\
(0.01)\end{array}$ & & $\begin{array}{c}0.028^{* * *} \\
(0.00)\end{array}$ \\
\hline Covariance instrument early onset of disorders & & & $0.200^{* * *}$ & $0.184^{* * *}$ & & & & $0.184^{* * *}$ \\
\hline Covariance instrument married & & & $\begin{array}{c}(0.03) \\
-0.367^{* * *}\end{array}$ & $-0.362^{* * *}$ & & & $\begin{array}{c}(0.01) \\
-0.537^{* * *}\end{array}$ & $\begin{array}{c}(0.01) \\
-0.535^{* * *}\end{array}$ \\
\hline & & & $(0.13)$ & $(0.13)$ & & & $(0.07)$ & $(0.07)$ \\
\hline Measurement model equations & & & & & & & & \\
\hline Depressed mood & & & & & & & & \\
\hline Mental Illness* & 1.000 & 1.000 & 1.000 & 1.000 & 1.000 & 1.000 & 1.000 & 1.000 \\
\hline & (.) & (.) & (.) & (.) & (.) & (.) & (.) & (.) \\
\hline Diminished pleasure & & & & & & & & \\
\hline Mental Illness* & $0.748^{* * *}$ & $0.748^{* * *}$ & $0.749 * * *$ & $0.749 * * *$ & $0.754^{* * *}$ & $0.754^{* * *}$ & $0.754 * * *$ & $0.754^{* * *}$ \\
\hline & $(0.04)$ & $(0.04)$ & $(0.04)$ & $(0.04)$ & $(0.03)$ & $(0.03)$ & $(0.03)$ & $(0.03)$ \\
\hline Significant weight change & & & & & & & & \\
\hline Mental IIIness* & $0.661 * * *$ & $0.661 * * *$ & $0.661 * * *$ & $0.661 * * *$ & $0.877 * * *$ & $0.877^{* * *}$ & $0.877^{* * *}$ & $0.877^{* * *}$ \\
\hline & $(0.05)$ & $(0.05)$ & $(0.05)$ & $(0.05)$ & $(0.02)$ & $(0.02)$ & $(0.02)$ & $(0.02)$ \\
\hline Insomnia or Hypersomnia & & & & & & & & \\
\hline Mental IIIness* & $0.934^{* * *}$ & $0.934^{* * *}$ & $0.934^{* * *}$ & $0.934^{* * *}$ & $0.943 * * *$ & $0.943^{* * *}$ & $0.943 * * *$ & $0.943 * * *$ \\
\hline & $(0.03)$ & $(0.03)$ & $(0.03)$ & $(0.03)$ & $(0.01)$ & $(0.01)$ & $(0.01)$ & $(0.01)$ \\
\hline Restlessness or retardation & & & & & & & & \\
\hline Mental Illness* & $0.567 * * *$ & $0.567^{* * *}$ & $0.567 * * *$ & $0.568^{* * *}$ & $0.525 * * *$ & $0.525 * * *$ & $0.525 * * *$ & $0.525 * * *$ \\
\hline & $(0.05)$ & $(0.05)$ & $(0.05)$ & $(0.05)$ & $(0.03)$ & $(0.03)$ & $(0.03)$ & $(0.03)$ \\
\hline Fatigue & & & & & & & & \\
\hline Mental Illness* & $0.814^{* * *}$ & $0.814^{* * *}$ & $0.814^{* * *}$ & $0.814 * * *$ & $0.955 * * *$ & $0.955 * * *$ & $0.955 * * *$ & $0.955 * * *$ \\
\hline & $(0.03)$ & $(0.03)$ & $(0.03)$ & $(0.03)$ & $(0.01)$ & $(0.01)$ & $(0.01)$ & $(0.01)$ \\
\hline Worthlessness & & & & & & & & \\
\hline Mental IIIness* & $0.469 * * *$ & $0.470^{* * *}$ & $0.471^{* * *}$ & $0.471^{* * *}$ & $0.525 * * *$ & $0.525 * * *$ & $0.526^{* * *}$ & $0.526^{* * *}$ \\
\hline & $(0.05)$ & $(0.05)$ & $(0.05)$ & $(0.05)$ & $(0.03)$ & $(0.03)$ & $(0.03)$ & $(0.03)$ \\
\hline Indecisiveness & & & & & & & & \\
\hline Mental Illness* & $0.918^{* * *}$ & $0.918^{* * *}$ & $0.918^{* * *}$ & $0.919 * * *$ & $0.956 * * *$ & $0.956 * *$ & $0.956 * * *$ & $0.956 * * *$ \\
\hline
\end{tabular}




\begin{tabular}{|c|c|c|c|c|c|c|c|c|}
\hline & $(0.03)$ & $(0.03)$ & $(0.03)$ & $(0.03)$ & $(0.01)$ & $(0.01)$ & $(0.01)$ & $(0.01)$ \\
\hline \multicolumn{9}{|l|}{ Suicidal thoughts } \\
\hline Mental Illness* & $\begin{array}{c}0.710^{* * *} \\
(0.04)\end{array}$ & $\begin{array}{c}0.711^{* * *} \\
(0.04)\end{array}$ & $\begin{array}{c}0.711^{* * *} \\
(0.04)\end{array}$ & $\begin{array}{c}0.711^{* * *} \\
(0.04)\end{array}$ & $\begin{array}{c}0.748^{* * *} \\
(0.03)\end{array}$ & $\begin{array}{c}0.748^{* * *} \\
(0.03)\end{array}$ & $\begin{array}{c}0.748^{* * *} \\
(0.03)\end{array}$ & $\begin{array}{c}0.748^{* * *} \\
(0.03)\end{array}$ \\
\hline \multicolumn{9}{|c|}{ Frequently severe emotional distress } \\
\hline Mental IIIness* & $\begin{array}{c}0.883^{* * *} \\
(0.02)\end{array}$ & $\begin{array}{c}0.883^{* * *} \\
(0.02)\end{array}$ & $\begin{array}{c}0.883^{* * *} \\
(0.02)\end{array}$ & $\begin{array}{c}0.883^{* * *} \\
(0.02)\end{array}$ & $\begin{array}{c}0.834^{* * *} \\
(0.03)\end{array}$ & $\begin{array}{c}0.834^{* * *} \\
(0.03)\end{array}$ & $\begin{array}{c}0.834^{* * *} \\
(0.03)\end{array}$ & $\begin{array}{c}0.834^{* * *} \\
(0.03)\end{array}$ \\
\hline \multicolumn{9}{|l|}{ Severe emotional distress } \\
\hline Mental Illness* & $\begin{array}{c}0.976^{* * *} \\
(0.01)\end{array}$ & $\begin{array}{c}0.977^{* * *} \\
(0.01)\end{array}$ & $\begin{array}{c}0.977^{* * *} \\
(0.01)\end{array}$ & $\begin{array}{c}0.977^{* * *} \\
(0.01)\end{array}$ & $\begin{array}{c}0.963^{* * *} \\
(0.01)\end{array}$ & $\begin{array}{c}0.963^{* * *} \\
(0.01)\end{array}$ & $\begin{array}{c}0.963 * * * \\
(0.01)\end{array}$ & $\begin{array}{c}0.963^{* * *} \\
(0.01)\end{array}$ \\
\hline \multicolumn{9}{|l|}{ Length of Depressive episode } \\
\hline Mental Illness* & $\begin{array}{c}0.763^{* * *} \\
(0.25)\end{array}$ & $\begin{array}{c}0.763^{* * *} \\
(0.25)\end{array}$ & $\begin{array}{c}0.762^{* * *} \\
(0.25)\end{array}$ & $\begin{array}{c}0.763^{* * *} \\
(0.25)\end{array}$ & $\begin{array}{c}0.648^{* * *} \\
(0.10)\end{array}$ & $\begin{array}{c}0.649 * * * \\
(0.10)\end{array}$ & $\begin{array}{c}0.650^{* * *} \\
(0.10)\end{array}$ & $\begin{array}{c}0.650^{* * *} \\
(0.10)\end{array}$ \\
\hline \multicolumn{9}{|l|}{ Sweating } \\
\hline Mental Illness* & $\begin{array}{c}0.132^{* * *} \\
(0.03)\end{array}$ & $\begin{array}{c}0.132^{* * *} \\
(0.03)\end{array}$ & $\begin{array}{c}0.132^{* * *} \\
(0.03)\end{array}$ & $\begin{array}{c}0.132^{* * *} \\
(0.03)\end{array}$ & $\begin{array}{c}0.085^{* * *} \\
(0.02)\end{array}$ & $\begin{array}{c}0.085^{* * *} \\
(0.02)\end{array}$ & $\begin{array}{c}0.085^{* * *} \\
(0.02)\end{array}$ & $\begin{array}{c}0.085^{* * *} \\
(0.02)\end{array}$ \\
\hline \multicolumn{9}{|l|}{ Trembling } \\
\hline Mental Illness* & $\begin{array}{c}0.111^{* * *} \\
(0.03)\end{array}$ & $\begin{array}{c}0.111^{* * *} \\
(0.03)\end{array}$ & $\begin{array}{c}0.111^{* * *} \\
(0.04)\end{array}$ & $\begin{array}{c}0.111^{* * *} \\
(0.04)\end{array}$ & $\begin{array}{c}0.054^{* * *} \\
(0.02)\end{array}$ & $\begin{array}{c}0.054^{* * * *} \\
(0.02)\end{array}$ & $\begin{array}{c}0.054^{* * *} \\
(0.02)\end{array}$ & $\begin{array}{c}0.054^{* * *} \\
(0.02)\end{array}$ \\
\hline Choking & & & & & & & & \\
\hline Mental Illness* & $\begin{array}{c}0.221^{* * *} \\
(0.05)\end{array}$ & $\begin{array}{c}0.222^{* * *} \\
(0.05)\end{array}$ & $\begin{array}{c}0.222^{* * *} \\
(0.05)\end{array}$ & $\begin{array}{c}0.222^{* * *} \\
(0.05)\end{array}$ & $\begin{array}{c}0.165^{* * *} \\
(0.02)\end{array}$ & $\begin{array}{c}0.165^{* * *} \\
(0.02)\end{array}$ & $\begin{array}{c}0.165^{* * *} \\
(0.02)\end{array}$ & $\begin{array}{c}0.165^{* * *} \\
(0.02)\end{array}$ \\
\hline Chest pain or nausea & & & & & & & & \\
\hline Mental Illness* & $\begin{array}{c}0.204^{* * *} \\
(0.05)\end{array}$ & $\begin{array}{c}0.204^{* * *} \\
(0.05)\end{array}$ & $\begin{array}{c}0.204^{* * *} \\
(0.05)\end{array}$ & $\begin{array}{c}0.205^{* * *} \\
(0.05)\end{array}$ & $\begin{array}{c}0.191^{* * *} \\
(0.03)\end{array}$ & $\begin{array}{c}0.191^{* * *} \\
(0.03)\end{array}$ & $\begin{array}{c}0.191^{* * *} \\
(0.03)\end{array}$ & $\begin{array}{c}0.191^{* * *} \\
(0.03)\end{array}$ \\
\hline Dizziness or unreality & & & & & & & & \\
\hline Mental Illness* & $\begin{array}{c}0.203^{* * *} \\
(0.04)\end{array}$ & $\begin{array}{c}0.204^{* * *} \\
(0.04)\end{array}$ & $\begin{array}{c}0.203^{* * *} \\
(0.04)\end{array}$ & $\begin{array}{c}0.204^{* * *} \\
(0.04)\end{array}$ & $\begin{array}{c}0.156^{* * *} \\
(0.03)\end{array}$ & $\begin{array}{c}0.156^{* * *} \\
(0.03)\end{array}$ & $\begin{array}{c}0.156^{* * *} \\
(0.03)\end{array}$ & $\begin{array}{c}0.156^{* * *} \\
(0.03)\end{array}$ \\
\hline Afraid meeting new people & & & & & & & & \\
\hline Mental Illness* & $\begin{array}{c}0.295^{* * *} \\
(0.06)\end{array}$ & $\begin{array}{c}0.297^{* * *} \\
(0.06)\end{array}$ & $\begin{array}{c}0.296 * * * \\
(0.06)\end{array}$ & $\begin{array}{c}0.298^{* * *} \\
(0.06)\end{array}$ & $\begin{array}{c}0.186^{* * * *} \\
(0.03)\end{array}$ & $\begin{array}{c}0.187^{* * *} \\
(0.03)\end{array}$ & $\begin{array}{c}0.187^{* * *} \\
(0.03)\end{array}$ & $\begin{array}{c}0.187^{* * *} \\
(0.03)\end{array}$ \\
\hline Afraid talking to authority & & & & & & & & \\
\hline Mental Illness* & $\begin{array}{c}0.240^{* * *} \\
(0.06)\end{array}$ & $\begin{array}{c}0.242^{* * *} \\
(0.06)\end{array}$ & $\begin{array}{c}0.241^{* * *} \\
(0.06)\end{array}$ & $\begin{array}{c}0.242 * * * \\
(0.06)\end{array}$ & $\begin{array}{c}0.144^{* * *} \\
(0.03)\end{array}$ & $\begin{array}{c}0.145^{* * *} \\
(0.03)\end{array}$ & $\begin{array}{c}0.145^{* * *} \\
(0.03)\end{array}$ & $\begin{array}{c}0.145^{* * *} \\
(0.03)\end{array}$ \\
\hline Shy at social gathering & & & & & & & & \\
\hline Mental Illness* & $\begin{array}{c}0.249 * * * \\
(0.05)\end{array}$ & $\begin{array}{c}0.251^{* * *} \\
(0.05)\end{array}$ & $\begin{array}{c}0.251^{* * *} \\
(0.05)\end{array}$ & $\begin{array}{c}0.252^{* * *} \\
(0.05)\end{array}$ & $\begin{array}{c}0.169 * * * \\
(0.02)\end{array}$ & $\begin{array}{c}0.169 * * * \\
(0.02)\end{array}$ & $\begin{array}{c}0.169 * * * \\
(0.02)\end{array}$ & $\begin{array}{c}0.170^{* * *} \\
(0.02)\end{array}$ \\
\hline Shy performing & & & & & & & & \\
\hline Mental Illness* & $\begin{array}{c}0.249 * * * \\
(0.06)\end{array}$ & $\begin{array}{c}0.250^{* * *} \\
(0.06)\end{array}$ & $\begin{array}{c}0.250^{* * *} \\
(0.06)\end{array}$ & $\begin{array}{c}0.251^{* * *} \\
(0.06)\end{array}$ & $\begin{array}{c}0.184^{* * *} \\
(0.03)\end{array}$ & $\begin{array}{c}0.184^{* * *} \\
(0.03)\end{array}$ & $\begin{array}{c}0.184^{* * *} \\
(0.03)\end{array}$ & $\begin{array}{c}0.185^{* * *} \\
(0.03)\end{array}$ \\
\hline Shy of unknown people & & & & & & & & \\
\hline Mental Illness* & $\begin{array}{c}0.226^{* * *} \\
(0.06)\end{array}$ & $\begin{array}{c}0.227^{* * *} \\
(0.06)\end{array}$ & $\begin{array}{c}0.227^{* * *} \\
(0.06)\end{array}$ & $\begin{array}{c}0.228^{* * *} \\
(0.06)\end{array}$ & $\begin{array}{c}0.139^{* * *} \\
(0.02)\end{array}$ & $\begin{array}{c}0.140^{* * *} \\
(0.02)\end{array}$ & $\begin{array}{c}0.140^{* * *} \\
(0.02)\end{array}$ & $\begin{array}{c}0.140^{* * *} \\
(0.02)\end{array}$ \\
\hline Shy at disagreement & & & & & & & & \\
\hline Mental Illness* & $\begin{array}{c}0.233^{* * *} \\
(0.05)\end{array}$ & $\begin{array}{c}0.234^{* * *} \\
(0.05)\end{array}$ & $\begin{array}{c}0.235^{* * *} \\
(0.05)\end{array}$ & $\begin{array}{c}0.235^{* * *} \\
(0.05)\end{array}$ & $\begin{array}{c}0.129^{* * *} \\
(0.03)\end{array}$ & $\begin{array}{c}0.130^{* * *} \\
(0.03)\end{array}$ & $\begin{array}{c}0.130^{* * *} \\
(0.03)\end{array}$ & $\begin{array}{c}0.130^{* * *} \\
(0.03)\end{array}$ \\
\hline Shy with others watching & & & & & & & & \\
\hline Mental Illness* & $\begin{array}{c}0.172^{* * *} \\
(0.05)\end{array}$ & $\begin{array}{c}0.173^{* * *} \\
(0.05)\end{array}$ & $\begin{array}{c}0.173^{* * *} \\
(0.05)\end{array}$ & $\begin{array}{c}0.173^{* * *} \\
(0.05)\end{array}$ & $\begin{array}{c}0.112^{* * *} \\
(0.03)\end{array}$ & $\begin{array}{c}0.112^{* * *} \\
(0.03)\end{array}$ & $\begin{array}{c}0.112^{* * *} \\
(0.03)\end{array}$ & $\begin{array}{c}0.113^{* * *} \\
(0.03)\end{array}$ \\
\hline Shy using public restroom & & & & & & & & \\
\hline Mental IIIness* & $\begin{array}{c}0.150^{* * *} \\
(0.04)\end{array}$ & $\begin{array}{c}0.150^{* * *} \\
(0.04)\end{array}$ & $\begin{array}{c}0.150^{* * *} \\
(0.04)\end{array}$ & $\begin{array}{c}0.151^{* * *} \\
(0.04)\end{array}$ & $\begin{array}{c}0.101^{* * *} \\
(0.02)\end{array}$ & $\begin{array}{c}0.102^{* * *} \\
(0.02)\end{array}$ & $\begin{array}{c}0.102^{* * *} \\
(0.02)\end{array}$ & $\begin{array}{c}0.102^{* * *} \\
(0.02)\end{array}$ \\
\hline Shy in dating situation & & & & & & & & \\
\hline Mental IIIness* & $\begin{array}{c}0.196^{* * *} \\
(0.05)\end{array}$ & $\begin{array}{c}0.197^{* * *} \\
(0.05)\end{array}$ & $\begin{array}{c}0.197^{* * *} \\
(0.05)\end{array}$ & $\begin{array}{c}0.198^{* * *} \\
(0.05)\end{array}$ & $\begin{array}{c}0.149^{* * *} \\
(0.03)\end{array}$ & $\begin{array}{c}0.150^{* * * *} \\
(0.03)\end{array}$ & $\begin{array}{c}0.150^{* * *} \\
(0.03)\end{array}$ & $\begin{array}{c}0.150^{* * *} \\
(0.03)\end{array}$ \\
\hline Uncomfortable getting atter & & & & & & & & \\
\hline Mental Illness* & $\begin{array}{c}0.266^{* * *} \\
(0.06)\end{array}$ & $\begin{array}{c}0.268^{* * *} \\
(0.06)\end{array}$ & $\begin{array}{c}0.267^{* * *} \\
(0.06)\end{array}$ & $\begin{array}{c}0.269^{* * *} \\
(0.06)\end{array}$ & $\begin{array}{c}0.172^{* * *} \\
(0.03)\end{array}$ & $\begin{array}{c}0.172^{* * *} \\
(0.03)\end{array}$ & $\begin{array}{c}0.172^{* * *} \\
(0.03)\end{array}$ & $\begin{array}{c}0.173^{* * *} \\
(0.03)\end{array}$ \\
\hline Fear of embarrassment & & & & & & & & \\
\hline Mental Illness* & $\begin{array}{c}0.300^{* * *} \\
(0.06)\end{array}$ & $\begin{array}{c}0.302^{* * *} \\
(0.06)\end{array}$ & $\begin{array}{c}0.302^{* * *} \\
(0.06)\end{array}$ & $\begin{array}{c}0.303^{* * *} \\
(0.07)\end{array}$ & $\begin{array}{c}0.199^{* * *} \\
(0.03)\end{array}$ & $\begin{array}{c}0.200^{* * *} \\
(0.03)\end{array}$ & $\begin{array}{c}0.200^{* * *} \\
(0.03)\end{array}$ & $\begin{array}{c}0.200^{* * *} \\
(0.03)\end{array}$ \\
\hline Fear of social situation & & & & & & & & \\
\hline Mental Illness* & $\begin{array}{c}0.266^{* * *} \\
(0.06)\end{array}$ & $\begin{array}{c}0.268^{* * *} \\
(0.06)\end{array}$ & $\begin{array}{c}0.268^{* * *} \\
(0.06)\end{array}$ & $\begin{array}{c}0.269^{* * *} \\
(0.06)\end{array}$ & $\begin{array}{c}0.182^{* * *} \\
(0.03)\end{array}$ & $\begin{array}{c}0.182^{* * *} \\
(0.03)\end{array}$ & $\begin{array}{c}0.183^{* * *} \\
(0.03)\end{array}$ & $\begin{array}{c}0.183^{* * *} \\
(0.03)\end{array}$ \\
\hline Avoid social situations & & & & & & & & \\
\hline Mental Illness* & $\begin{array}{c}0.323^{* * *} \\
(0.06)\end{array}$ & $\begin{array}{c}0.325^{* * *} \\
(0.06)\end{array}$ & $\begin{array}{c}0.325^{* * *} \\
(0.06)\end{array}$ & $\begin{array}{c}0.326^{* * *} \\
(0.07)\end{array}$ & $\begin{array}{c}0.196^{* * *} \\
(0.03)\end{array}$ & $\begin{array}{c}0.196^{* * *} \\
(0.03)\end{array}$ & $\begin{array}{c}0.196^{* * *} \\
(0.03)\end{array}$ & $\begin{array}{c}0.197^{* * *} \\
(0.03)\end{array}$ \\
\hline Social situations cause inten & & & & & & & & \\
\hline Mental Illness* & $\begin{array}{c}0.274^{* * *} \\
(0.06)\end{array}$ & $\begin{array}{c}0.276^{* * *} \\
(0.06)\end{array}$ & $\begin{array}{c}0.276^{* * *} \\
(0.06)\end{array}$ & $\begin{array}{c}0.277^{* * *} \\
(0.06)\end{array}$ & $\begin{array}{c}0.192^{* * *} \\
(0.03)\end{array}$ & $\begin{array}{c}0.193^{* * *} \\
(0.03)\end{array}$ & $\begin{array}{c}0.193^{* * *} \\
(0.03)\end{array}$ & $\begin{array}{c}0.193^{* * *} \\
(0.03)\end{array}$ \\
\hline Recent occurrence after age & & & & & & & & \\
\hline Mental IIIness* & $\begin{array}{c}0.325^{* * *} \\
(0.06)\end{array}$ & $\begin{array}{c}0.327^{* * *} \\
(0.07)\end{array}$ & $\begin{array}{c}0.327^{* * *} \\
(0.07)\end{array}$ & $\begin{array}{c}0.328^{* * *} \\
(0.07)\end{array}$ & $\begin{array}{c}0.196^{* * *} \\
(0.03)\end{array}$ & $\begin{array}{c}0.197^{* * *} \\
(0.03)\end{array}$ & $\begin{array}{c}0.197^{* * *} \\
(0.03)\end{array}$ & $\begin{array}{c}0.197 * * * \\
(0.03)\end{array}$ \\
\hline Excess anxiety & & & & & & & & \\
\hline Mental Illness* & $\begin{array}{c}0.392^{* * *} \\
(0.06)\end{array}$ & $\begin{array}{c}0.393^{* * *} \\
(0.06)\end{array}$ & $\begin{array}{c}0.394^{* * *} \\
(0.06)\end{array}$ & $\begin{array}{c}0.394^{* * *} \\
(0.06)\end{array}$ & $\begin{array}{c}0.344^{* * *} \\
(0.04)\end{array}$ & $\begin{array}{c}0.344^{* * *} \\
(0.04)\end{array}$ & $\begin{array}{c}0.344^{* * *} \\
(0.04)\end{array}$ & $\begin{array}{c}0.344^{* * *} \\
(0.04)\end{array}$ \\
\hline Length of GAD episode & & & & & & & & \\
\hline Mental IIIness* & $\begin{array}{c}0.537^{* *} \\
(0.23)\end{array}$ & $\begin{array}{c}0.538^{* *} \\
(0.23)\end{array}$ & $\begin{array}{c}0.536^{* *} \\
(0.23)\end{array}$ & $\begin{array}{c}0.537^{* *} \\
(0.23)\end{array}$ & $\begin{array}{c}0.379^{* * *} \\
(0.12)\end{array}$ & $\begin{array}{c}0.380^{* * * *} \\
(0.12)\end{array}$ & $\begin{array}{c}0.381^{* * *} \\
(0.12)\end{array}$ & $\begin{array}{c}0.381^{* * *} \\
(0.12)\end{array}$ \\
\hline Difficult to control worry & & & & & & & & \\
\hline Mental Illness* & $\begin{array}{c}0.380^{* * *} \\
(0.06)\end{array}$ & $\begin{array}{c}0.381^{* * *} \\
(0.06)\end{array}$ & $\begin{array}{c}0.382^{* * * *} \\
(0.06)\end{array}$ & $\begin{array}{c}0.382^{* * *} \\
(0.06)\end{array}$ & $\begin{array}{c}0.327^{* * *} \\
(0.04)\end{array}$ & $\begin{array}{c}0.328^{* * *} \\
(0.04)\end{array}$ & $\begin{array}{c}0.328^{* * *} \\
(0.04)\end{array}$ & $\begin{array}{c}0.328^{* * *} \\
(0.04)\end{array}$ \\
\hline Restlessness & & & & & & & & \\
\hline Mental Illness* & $\begin{array}{c}0.363^{* * *} \\
(0.06)\end{array}$ & $\begin{array}{c}0.364^{* * *} \\
(0.06)\end{array}$ & $\begin{array}{c}0.364^{* * *} \\
(0.06)\end{array}$ & $\begin{array}{c}0.365^{* * *} \\
(0.06)\end{array}$ & $\begin{array}{c}0.306^{* * *} \\
(0.04)\end{array}$ & $\begin{array}{c}0.306^{* * *} \\
(0.04)\end{array}$ & $\begin{array}{c}0.306^{* * *} \\
(0.04)\end{array}$ & $\begin{array}{c}0.307^{* * *} \\
(0.04)\end{array}$ \\
\hline Tired & & & & & & & & \\
\hline Mental Illness* & $\begin{array}{c}0.291^{* * *} \\
(0.06)\end{array}$ & $\begin{array}{c}0.292^{* * *} \\
(0.06)\end{array}$ & $\begin{array}{c}0.292^{* * *} \\
(0.06)\end{array}$ & $\begin{array}{c}0.293^{* * *} \\
(0.06)\end{array}$ & $\begin{array}{c}0.310^{* * *} \\
(0.04)\end{array}$ & $\begin{array}{c}0.311^{* * *} \\
(0.04)\end{array}$ & $\begin{array}{c}0.311^{* * *} \\
(0.04)\end{array}$ & $\begin{array}{c}0.311^{* * *} \\
(0.04)\end{array}$ \\
\hline Irritable & & & & & & & & \\
\hline Mental Illness* & $\begin{array}{c}0.333^{* * *} \\
(0.06)\end{array}$ & $\begin{array}{c}0.334^{* * *} \\
(0.06)\end{array}$ & $\begin{array}{c}0.334^{* * *} \\
(0.06)\end{array}$ & $\begin{array}{c}0.335^{* * *} \\
(0.06)\end{array}$ & $\begin{array}{c}0.303^{* * *} \\
(0.04)\end{array}$ & $\begin{array}{c}0.303^{* * *} \\
(0.04)\end{array}$ & $\begin{array}{c}0.303^{* * *} \\
(0.04)\end{array}$ & $\begin{array}{c}0.303^{* * *} \\
(0.04)\end{array}$ \\
\hline Difficulty concentrating & & & & & & & & \\
\hline Mental Illness* & $\begin{array}{c}0.363^{* * *} \\
(0.06)\end{array}$ & $\begin{array}{c}0.365^{* * *} \\
(0.06)\end{array}$ & $\begin{array}{c}0.365^{* * *} \\
(0.06)\end{array}$ & $\begin{array}{c}0.366^{* * *} \\
(0.06)\end{array}$ & $\begin{array}{c}0.302^{* * *} \\
(0.04)\end{array}$ & $\begin{array}{c}0.302^{* * *} \\
(0.04)\end{array}$ & $\begin{array}{c}0.302^{* * *} \\
(0.04)\end{array}$ & $\begin{array}{c}0.303^{* * *} \\
(0.04)\end{array}$ \\
\hline Tense muscles & & & & & & & & \\
\hline Mental IIIness* & $\begin{array}{c}0.204^{* * *} \\
(0.04)\end{array}$ & $\begin{array}{c}0.205^{* * *} \\
(0.04)\end{array}$ & $\begin{array}{c}0.205^{* * *} \\
(0.04)\end{array}$ & $\begin{array}{c}0.205^{* * *} \\
(0.04)\end{array}$ & $\begin{array}{c}0.266^{* * *} \\
(0.03)\end{array}$ & $\begin{array}{c}0.266^{* * *} \\
(0.03)\end{array}$ & $\begin{array}{c}0.266^{* * *} \\
(0.03)\end{array}$ & $\begin{array}{c}0.266^{* * *} \\
(0.03)\end{array}$ \\
\hline Sleeping problems & & & & & & & & \\
\hline Mental IIIness* & $\begin{array}{c}0.329 * * * \\
(0.05)\end{array}$ & $\begin{array}{c}0.330^{* * *} \\
(0.05)\end{array}$ & $\begin{array}{c}0.330^{* * *} \\
(0.05)\end{array}$ & $\begin{array}{c}0.331^{* * *} \\
(0.05)\end{array}$ & $\begin{array}{c}0.301^{* * *} \\
(0.04)\end{array}$ & $\begin{array}{c}0.301^{* * *} \\
(0.04)\end{array}$ & $\begin{array}{c}0.301^{* * *} \\
(0.04)\end{array}$ & $\begin{array}{c}0.301^{* * *} \\
(0.04)\end{array}$ \\
\hline
\end{tabular}




\begin{tabular}{|c|c|c|c|c|c|c|c|c|}
\hline Mental Illness* & $\begin{array}{c}0.316 * * * \\
(0.06)\end{array}$ & $\begin{array}{c}0.317^{* * *} \\
(0.06)\end{array}$ & $\begin{array}{c}0.317^{* * *} \\
(0.06)\end{array}$ & $\begin{array}{c}0.318^{* * *} \\
(0.06)\end{array}$ & $\begin{array}{c}0.293^{* * *} \\
(0.04)\end{array}$ & $\begin{array}{c}0.294^{* * *} \\
(0.04)\end{array}$ & $\begin{array}{c}0.294^{* * *} \\
(0.04)\end{array}$ & $\begin{array}{c}0.294^{* * *} \\
(0.04)\end{array}$ \\
\hline \multicolumn{9}{|l|}{ Significant emotional distress } \\
\hline Mental Illness* & $\begin{array}{c}0.375^{* * *} \\
(0.06)\end{array}$ & $\begin{array}{c}0.376^{* * *} \\
(0.06)\end{array}$ & $\begin{array}{c}0.376^{* * *} \\
(0.06)\end{array}$ & $\begin{array}{c}0.377^{* * *} \\
(0.06)\end{array}$ & $\begin{array}{c}0.333^{* * *} \\
(0.04)\end{array}$ & $\begin{array}{c}0.333^{* * *} \\
(0.04)\end{array}$ & $\begin{array}{c}0.333^{* * *} \\
(0.04)\end{array}$ & $\begin{array}{c}0.334^{* * *} \\
(0.04)\end{array}$ \\
\hline \multicolumn{9}{|c|}{ Worry not always due to physical causes } \\
\hline Mental Illness* & $\begin{array}{c}0.160^{* * *} \\
(0.04)\end{array}$ & $\begin{array}{c}0.161^{* * *} \\
(0.04)\end{array}$ & $\begin{array}{c}0.161^{* * *} \\
(0.04)\end{array}$ & $\begin{array}{c}0.161^{* * *} \\
(0.04)\end{array}$ & $\begin{array}{c}0.053^{* * *} \\
(0.02)\end{array}$ & $\begin{array}{c}0.054^{* * *} \\
(0.02)\end{array}$ & $\begin{array}{c}0.054^{* * *} \\
(0.02)\end{array}$ & $\begin{array}{c}0.054^{* * *} \\
(0.02)\end{array}$ \\
\hline$N$ & 2698 & 2698 & 2698 & 2698 & 2779 & 2779 & 2779 & 2779 \\
\hline
\end{tabular}




\section{Figure 1: Distributions of latent indices of psychiatric disorders}
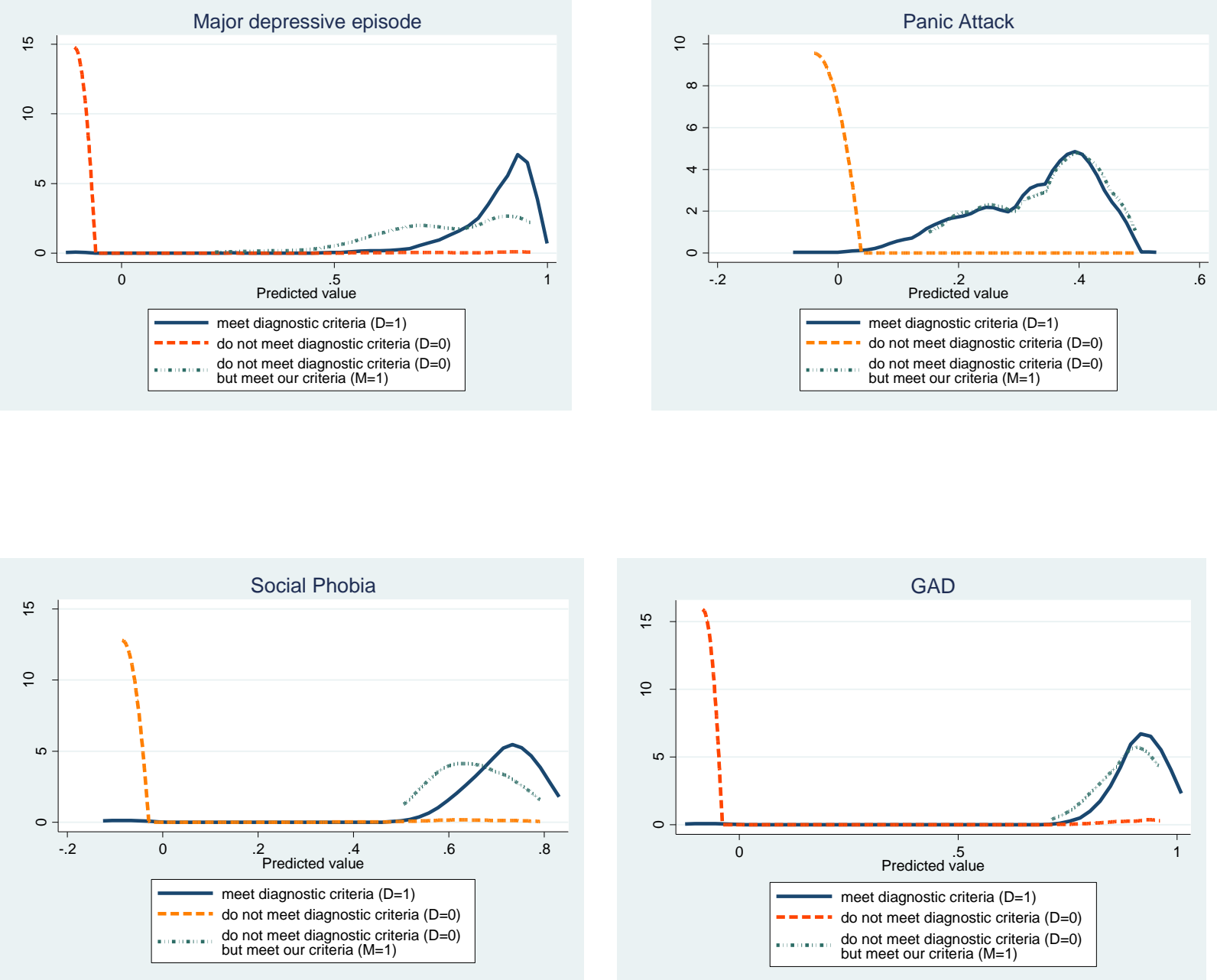
Table 12.1: Contingency table

Clinical diagnosis

\begin{tabular}{c|cccc|} 
Our & & Yes & No & Total \\
diagnosis & Yes & $a$ (hit) & $b$ (false alarm) & $a+b$ \\
& No & $c$ (miss) & $d$ (correct rejection) & $c+d$ \\
& Total & $a+c$ & $b+d$ & $a+b+c+d$ \\
\cline { 2 - 5 } & & & &
\end{tabular}

Table 12.2: Concordance measures for psychiatric disorders

\begin{tabular}{|c|c|c|c|c|c|c|c|c|c|c|c|c|c|c|c|c|}
\hline \multirow[b]{3}{*}{$\mathrm{t}$} & \multicolumn{4}{|c|}{ Depression } & \multicolumn{4}{|c|}{ Panic Attack } & \multicolumn{4}{|c|}{ Social Phobia } & \multicolumn{4}{|c|}{ GAD } \\
\hline & (1) & (2) & (3) & (4) & (5) & (6) & (7) & (8) & (9) & (10) & (11) & (12) & (13) & (14) & (15) & (16) \\
\hline & $H$ & $F$ & $P S$ & $O R$ & $H$ & $F$ & $P S$ & $O R$ & $H$ & $F$ & $P S$ & $O R$ & $H$ & $F$ & $P S$ & $O R$ \\
\hline 0 & & & & & 0.9956 & 0.0029 & 0.9927 & 78742.66 & & & & & & & & \\
\hline 0.1 & & & & & 0.9768 & 0.0029 & 0.9739 & 14715.61 & & & & & 0.9896 & 0.0517 & 0.9380 & 1752.72 \\
\hline 0.2 & 0.9953 & 0.0262 & 0.9691 & 7907.63 & 0.8785 & 0.0027 & 0.8758 & 2667.27 & & & & & 0.9896 & 0.0514 & 0.9382 & 1762.74 \\
\hline 0.3 & 0.9930 & 0.0258 & 0.9672 & 5353.03 & 0.6265 & 0.0020 & 0.6246 & 857.86 & 0.9843 & 0.0456 & 0.9387 & 1310.24 & 0.9896 & 0.0511 & 0.9385 & 1772.87 \\
\hline 0.4 & 0.9918 & 0.0255 & 0.9663 & 4637.94 & 0.3050 & 0.0011 & 0.3039 & 417.10 & 0.9843 & 0.0436 & 0.9407 & 1373.88 & 0.9896 & 0.0511 & 0.9385 & 1772.87 \\
\hline 0.5 & 0.9895 & 0.0249 & 0.9646 & 3687.24 & & & & & 0.9843 & 0.0395 & 0.9447 & 1520.68 & 0.9896 & 0.0511 & 0.9385 & 1772.87 \\
\hline 0.6 & 0.9766 & 0.0224 & 0.9543 & 1828.05 & & & & & 0.9481 & 0.0289 & 0.9193 & 614.88 & 0.9896 & 0.0511 & 0.9385 & 1772.87 \\
\hline 0.7 & 0.9509 & 0.0174 & 0.9335 & 1092.12 & & & & & 0.6352 & 0.0123 & 0.6230 & 140.23 & 0.9896 & 0.0511 & 0.9385 & 1772.87 \\
\hline 0.8 & 0.8376 & 0.0124 & 0.8252 & 411.85 & & & & & & & & & 0.9741 & 0.0465 & 0.9276 & 770.69 \\
\hline 0.9 & 0.5537 & 0.0080 & 0.5457 & 152.94 & & & & & & & & & 0.7150 & 0.0263 & 0.6887 & 92.81 \\
\hline
\end{tabular}


Table 13. Contingency tables for psychiatric disorders

I. Major Depressive Episode

Cutoff point: 0.2

Clinical diagnosis

$$
\begin{aligned}
& \text { Our } \\
& \text { diagnosis }
\end{aligned}
$$

\begin{tabular}{|c}
\hline Yes \\
No \\
Total
\end{tabular}

Yes
852
4
856

\begin{tabular}{cc|} 
No & Total \\
176 & 1,028 \\
6,534 & 6,538 \\
6,710 & 7,566 \\
\hline
\end{tabular}

III. Social Phobia

Cutoff point: 0.5

Clinical diagnosis

\begin{tabular}{c|cccc|}
\cline { 2 - 5 } Our & & Yes & No & Total \\
diagnosis & Yes & 626 & 274 & 900 \\
& No & 10 & 6,656 & 6,666 \\
& Total & 636 & 6,930 & 7,566 \\
\hline
\end{tabular}

II. Panic Attack

Cutoff point: 0.0

$$
\text { Our }
$$

diagnosis
Clinical diagnosis

\begin{tabular}{|cccc|}
\hline & Yes & No & Total \\
Yes & 901 & 19 & 920 \\
No & 4 & 6,642 & 6,646 \\
Total & 905 & 6,661 & 7,566 \\
\hline
\end{tabular}

IV.Generalized Anxiety Disorder Cutoff point: 0.3

Clinical diagnosis

Our

diagnosis

\begin{tabular}{|cccc|}
\hline & Yes & No & Total \\
Yes & 382 & 367 & 749 \\
No & 4 & 6,813 & 6,817 \\
Total & 386 & 7,180 & 7,566 \\
\hline
\end{tabular}


Table 14: Labor market benefits from improved mental health of diagnosed individuals $(D=1)$

\begin{tabular}{|c|c|c|c|c|}
\hline \multirow[b]{2}{*}{ Mean predicted outcome } & \multicolumn{2}{|c|}{ Males } & \multicolumn{2}{|c|}{ Females } \\
\hline & $\begin{array}{c}\text { Symptoms of } \mathrm{D}=1 \\
\text { (Original mental } \\
\text { health profile) }\end{array}$ & $\begin{array}{c}\text { Symptoms of D=0 } \\
\text { (Simulated mental } \\
\text { health profile) }\end{array}$ & $\begin{array}{c}\text { Symptoms of } \mathrm{D}=1 \\
\text { (Original mental } \\
\text { health profile) }\end{array}$ & $\begin{array}{c}\text { Symptoms of } \mathrm{D}=0 \\
\text { (Simulated mental } \\
\text { health profile) }\end{array}$ \\
\hline \multirow[t]{2}{*}{ Employment } & 0.72 & 0.87 & 0.63 & 0.74 \\
\hline & $(0.01)$ & $(0.01)$ & $(0.01)$ & $(0.01)$ \\
\hline \multirow[t]{2}{*}{ Labor force participation } & 0.75 & 0.88 & 0.69 & 0.79 \\
\hline & $(0.01)$ & $(0.01)$ & $(0.01)$ & $(0.00)$ \\
\hline \multirow[t]{2}{*}{ \# weeks worked among employed } & 48.22 & 50.74 & 48.80 & 49.61 \\
\hline & $(0.24)$ & $(0.11)$ & $(0.08)$ & $(0.06)$ \\
\hline \multirow[t]{2}{*}{ \# days missed among employed } & 2.03 & 0.89 & 1.50 & 1.16 \\
\hline & $(0.10)$ & $(0.04)$ & $(0.03)$ & $(0.02)$ \\
\hline
\end{tabular}

Note: Standard errors in parentheses; mental disorders considered are Depression, Panic Attack, Social Phobia and GAD

Table 15: Adverse labor market outcomes due to worsening mental health of undiagnosed individuals $(D=0)$

\begin{tabular}{|c|c|c|c|c|}
\hline \multirow[b]{2}{*}{ Mean predicted outcome } & \multicolumn{2}{|c|}{ Males } & \multicolumn{2}{|c|}{ Females } \\
\hline & $\begin{array}{c}\text { Symptoms of } \mathrm{D}=0 \\
\text { (Original mental } \\
\text { health profile) }\end{array}$ & $\begin{array}{c}\text { Symptoms of } \mathrm{D}=1 \\
\text { (Simulated mental } \\
\text { health profile) }\end{array}$ & $\begin{array}{c}\text { Symptoms of } \mathrm{D}=0 \\
\text { (Original mental } \\
\text { health profile) }\end{array}$ & $\begin{array}{c}\text { Symptoms of } \mathrm{D}=1 \\
\text { (Simulated mental } \\
\text { health profile) }\end{array}$ \\
\hline \multirow[t]{2}{*}{ Employment } & 0.87 & 0.71 & 0.71 & 0.60 \\
\hline & $(0.00)$ & $(0.01)$ & $(0.01)$ & $(0.01)$ \\
\hline \multirow[t]{2}{*}{ Labor force participation } & 0.88 & 0.75 & 0.77 & 0.67 \\
\hline & $(0.00)$ & $(0.01)$ & $(0.01)$ & $(0.01)$ \\
\hline \multirow[t]{2}{*}{ \# weeks worked among employed } & 50.85 & 47.77 & 49.62 & 48.68 \\
\hline & $(0.06)$ & $(0.13)$ & $(0.04)$ & $(0.06)$ \\
\hline \multirow[t]{2}{*}{ \# days missed among employed } & 0.91 & 2.31 & 1.12 & 1.51 \\
\hline & $(0.02)$ & $(0.05)$ & $(0.02)$ & $(0.02)$ \\
\hline
\end{tabular}

Note: Standard errors in parentheses; mental disorders considered are Depression, Panic Attack, Social Phobia and GAD 